\title{
Investigation and Design Studies of SOFC Electrode Performance at
} Elevated Pressure

\author{
Final Scientific/Technical Report \\ Reporting Period Start: October 1, 2007 \\ Reporting Period End: November 30, 2010 \\ Reported by: \\ Ted Ohrn, Project Manager \\ Shung Ik Lee, George Xing \\ December 2010 \\ Cooperative Agreement: DE-FC26-07NT43289
}

Rolls-Royce Fuel Cell Systems (US) Inc.

6065 Strip Avenue

North Canton, $\mathrm{OH} 44720$ 


\section{Disclaimer:}

This report was prepared as an account of work sponsored by an agency of the United States Government. Neither Rolls-Royce Fuel Cell Systems (US) Inc. nor the United States Government nor any agency thereof, nor any of their employees, makes any warranty, express or implied, or assumes any legal liability or responsibility for the accuracy, completeness, or usefulness of any information, apparatus, product, or process disclosed, or represents that its use would not infringe privately owned rights. Reference herein to any specific commercial product, process, or service by trade name, trademark, manufacturer, or otherwise does not necessarily constitute or imply its endorsement, recommendation, or favoring by the United States Government or any agency thereof. The views and opinions of authors expressed herein do not necessarily state or reflect those of the United States Government or any agency thereof. 
Final Report: DE-FC26-07NT43289

\begin{abstract}
An experimental program was set forth to study fuel cell performance at pressure and under various compositions. Improvement in cathode electrode performance is on the order of $33-40 \%$ at pressures of 6.4 Bara compared to atmospheric pressure. Key cathode operational parameters are the concentration and partial pressure of $\mathrm{O}_{2}$, and temperature. The effect of partial pressure of oxygen $\left(\mathrm{P}_{\mathrm{O} 2}\right)$ decreases the activation polarization, although there appears to be a secondary effect of absolute pressure as well. The concentration of oxygen impacts the diffusion component of the polarization, which is largely insensitive to absolute pressure. The effect of pressure was found to reduce the total polarization resistance of full fuel-cells beyond the reduction determined for the cathode alone. The total reduction in ASR was on the order of $0.10 \mathrm{ohm}-\mathrm{cm}^{2}$ for a pressure increase from 1 to 6.5 Bara, with about $70 \%$ of the improvement being realized from 1 to 4 Bara. An important finding was that there is an effect of steam on the cathode that is highly temperature dependent. The loss of performance at temperatures below $850^{\circ} \mathrm{C}$ was very large for the standard LSM + YSZ cathodes.
\end{abstract}


Table of Contents

Disclaimer

Abstract.

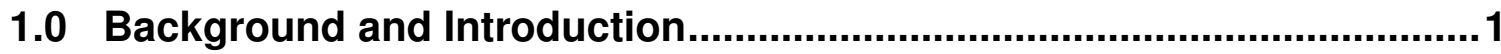

2.0 Literature Review of the Effect of Pressure on SOFC Performance ......3

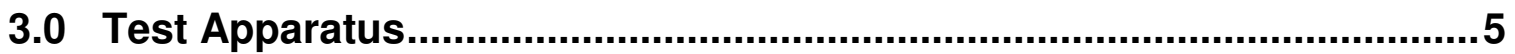

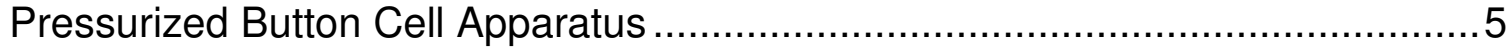

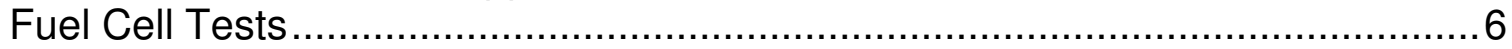

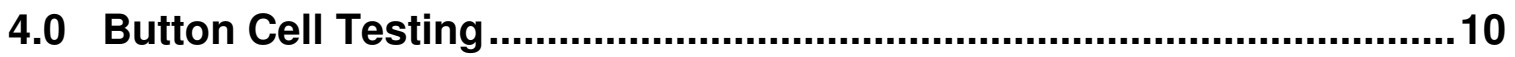

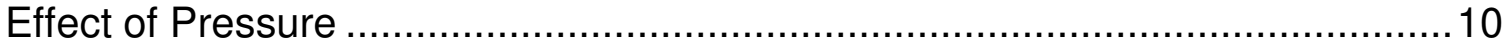

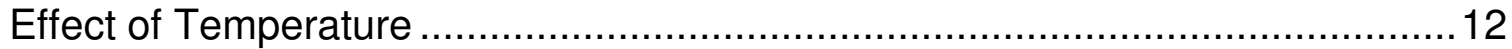

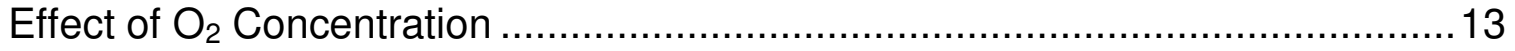

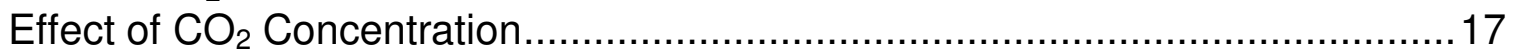

Effect of Steam Concentration ................................................................ 18

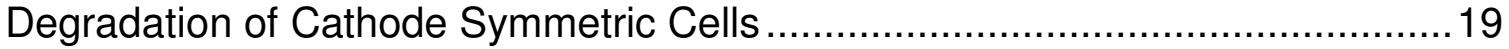

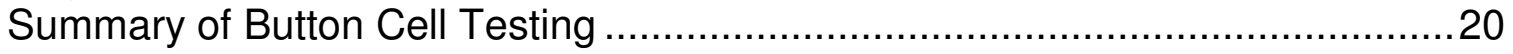

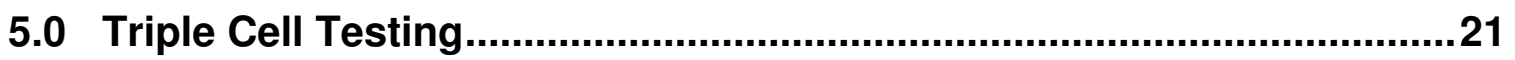

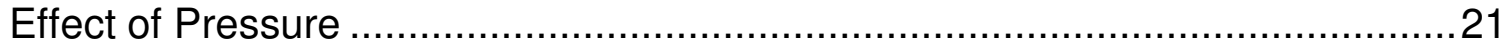

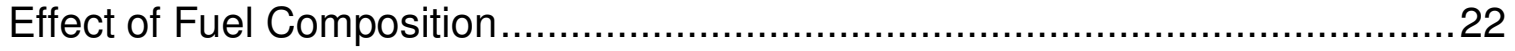

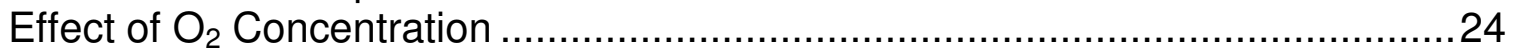

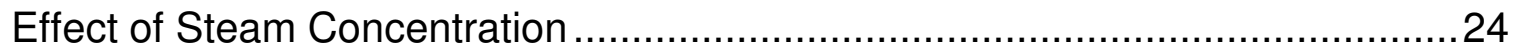

Effect of Temperature and Burn-in (plus steam) ..........................................26

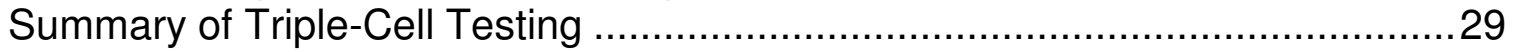

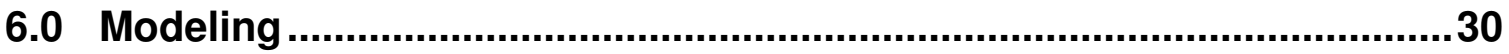

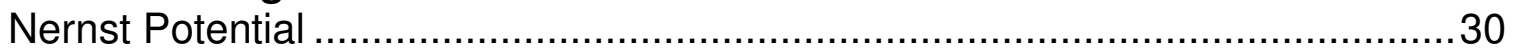

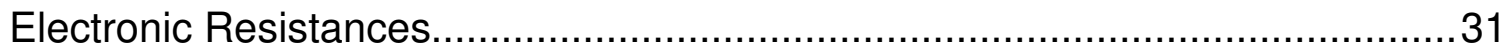

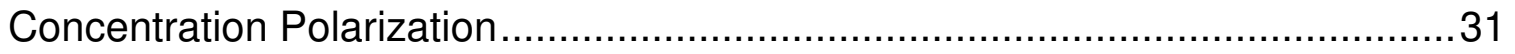

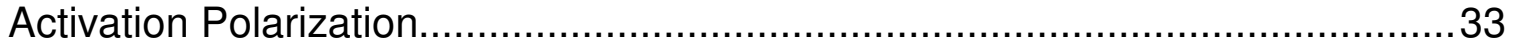

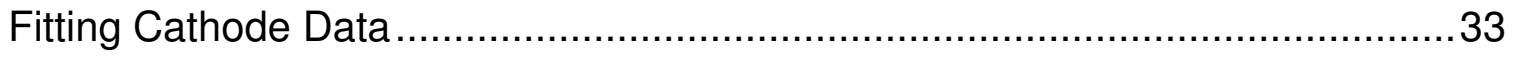

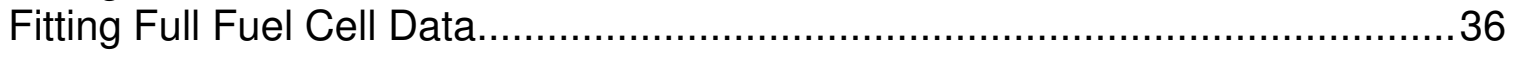

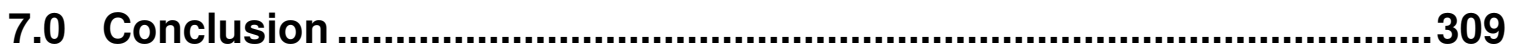

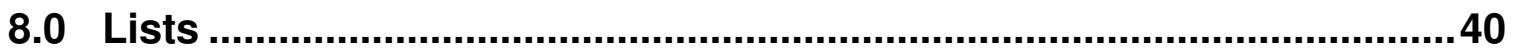

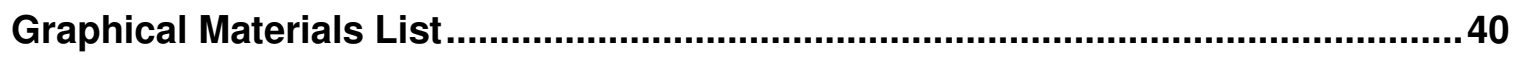

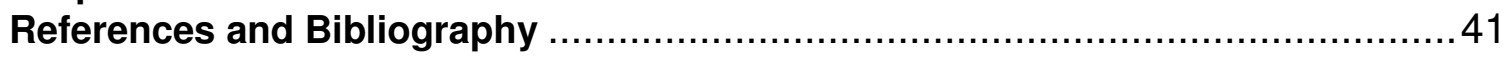

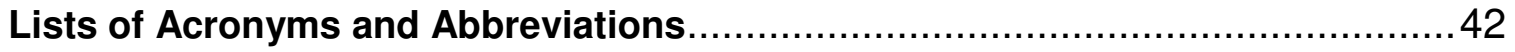


Final Report: DE-FC26-07NT43289

\section{Executive Summary}

The operation of the Rolls-Royce solid oxide fuel cell (SOFC) system is at pressures up to 7 atmospheres. The original Roll-Royce SOFC system featured anode recycle and anode off-gas combustion that creates unique gas conditions, especially at the cathode, that are outside the range of that typical for SOFCs: lower oxygen fractions, steam and carbon dioxide on the cathode and high steam contents on the anode. There is limited data on the performance of electrodes under such elevated pressure conditions and compositions.

Test apparatus to study cathode performance at pressure and under various compositions was constructed as part of this program. In addition, this program utilized existing test capability which included both ambient and pressurized test stands for full fuel cells. These stands are capable of supplying fuel cells with a range of anode and cathode compositions which encompass the operation of the Rolls-Royce system.

Improvement in cathode electrode performance is on the order of $33-40 \%$ at pressures of 6.4 Bara compared to atmospheric pressure. Key cathode operational parameters are the concentration and partial pressure of $\mathrm{O}_{2}$, and temperature. $\mathrm{CO}_{2}$ showed negligible impact on short term electrode performance. Steam at levels below $20 \%$ also showed negligible impact on short term electrode performance, but has been found to cause a longer-term loss of performance, especially at lower temperatures.

The effect of partial pressure of $\mathrm{O}_{2}\left(\mathrm{P}_{\mathrm{O}}\right)$ decreases the activation polarization, although there appears to be a secondary effect of absolute pressure as well. The concentration of $\mathrm{O}_{2}$ impacts the diffusion component of the polarization, which is largely insensitive to absolute pressure.

The effect of pressure on long term cathode performance was not established. In general, due to the non-prototypic nature of the current collecting for the button cell samples compared to the full cells, and their apparent instability during long-term testing, the degradation tests were not considered to be as valuable as hoped for deconvolution of degradation results.

The effect of pressure was found to reduce the polarization resistance of the full fuel-cell beyond the reduction determined for the cathode alone. The total reduction in ASR was on the order of $0.10 \mathrm{ohm}-\mathrm{cm}^{2}$ for a pressure increase from 1 to $6.5 \mathrm{Bara}$, with about $70 \%$ of the improvement being realized from 1 to 4 Bara. The effect of the change in fuel composition is on the order of 0.09 to $0.10 \mathrm{ohm}-\mathrm{cm}^{2}$, although the degree to which fuel composition affects performance is highly dependent upon the permeability of the substrates.

An important finding was that the effect of steam was highly temperature dependent. The loss of performance at temperatures below $850^{\circ} \mathrm{C}$ was very large for the standard LSM + YSZ cathodes. Steam is also a major factor in the degradation rate. Data at pressure was insufficient to substantiate the effect of pressure on degradation.

The test facilities in use and the data produced by them provide sufficient detail and range of operation to provide a robust set of data for model development and validation. 


\subsection{Background and Introduction}

The operation of the Rolls-Royce solid oxide fuel cell (SOFC) system is at pressures up to 7 atmospheres. The Roll-Royce SOFC system features anode recycle and anode offgas combustion that creates unique gas conditions, especially at the cathode, that are outside the range of that typical for SOFCs: lower oxygen fractions, steam and carbon dioxide on the cathode and high steam contents on the anode. There is limited data on the performance of electrodes under such elevated pressure conditions and compositions. Further investigations of the performance of electrodes at high pressure, and while under the system prototypic gas compositions present in the Rolls-Royce design, is a critical research area for Rolls-Royce in its development and commercialization of a $1 \mathrm{MW}$ distributed power plant, as well as for the US Dept. of Energy in its emphasis on large combined cycle centralized power stations using SOFC technology.

The fundamental building block of the $1 \mathrm{MW}$ power system is individual substrates containing a large number of small cells connected in series as shown in Figure 1.1.

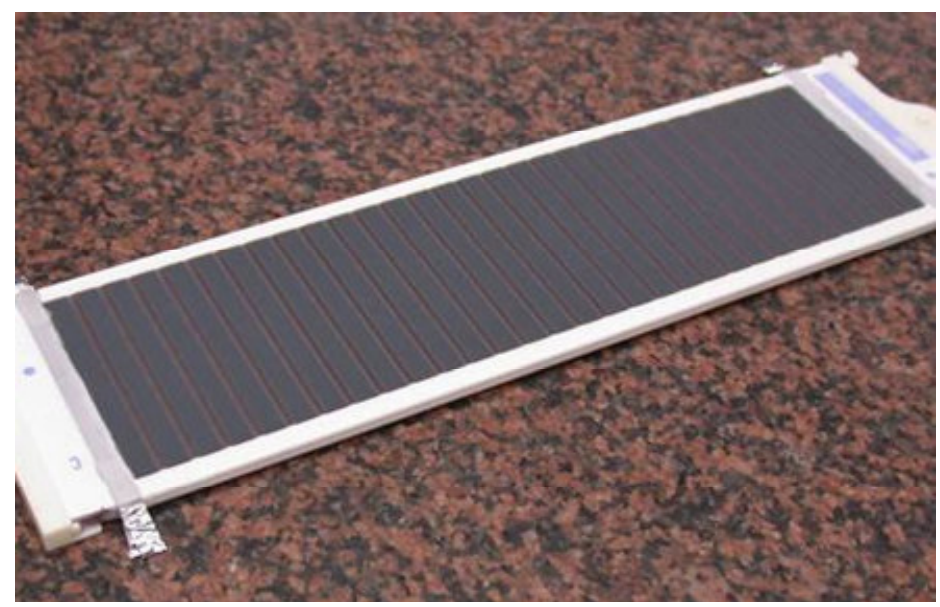

Figure 1. 1 - Rolls-Royce Series Connected Cells on Substrate

The cells consist of printed active cell layers on a substrate as shown in Figure 1.2. The cells progressively build up voltage for as many cells as are connected in series. This design is amenable to mass manufacturing techniques and also provides flexibility in scale-up and material changes as technology improvements are made. The high voltage low current also minimizes ohmic losses. 


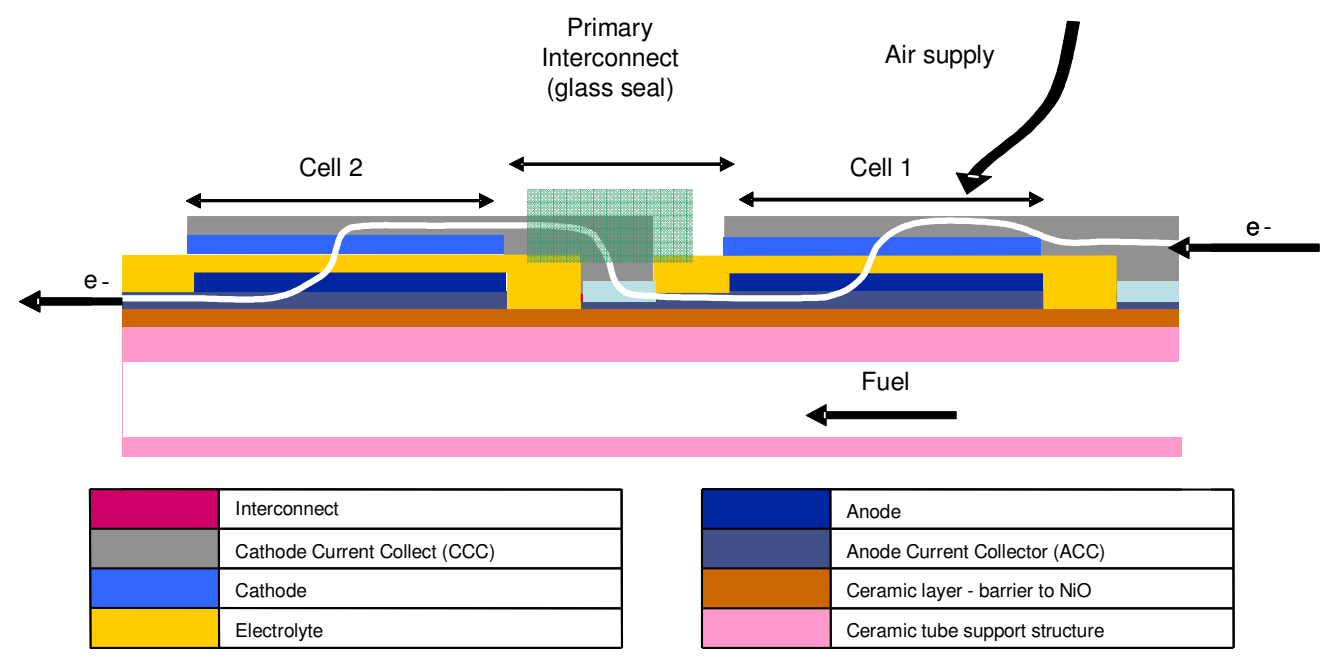

Figure 1. 2 - Schematic of Series Connected Cell

\section{Program Summary}

RRFCS has test facilities in North Canton, Ohio capable of testing both cathode symmetric cells and subscale substrates at the 1MW system prototypic pressures and gas compositions. The objective of testing cathode symmetric cells, at similar temperature and pressure conditions, is to compare to the full cell test data and aid deconvolution of the ASR contributions of the cell between the anode and cathode. Subscale substrates with 3 cells per substrate and having a high level of instrumentation are used to provide a breakdown of various cell components. Detailed electrochemical impedance analysis is also used to sort out ohmic and non-ohmic contributions of the active cell layers.

This project pursued a detailed investigation of the performance (ASR and degradation) of button cells and fuel cells under the full pressurized operating conditions and representative system gas compositions. The objective is to further define the performance difference for cells between ambient and pressurized operation. In both pressurized and ambient testing, anode and cathode side gas compositions were systematically varied to examine activation and concentration polarization processes for each electrode.

A limited number of longer-term tests (500-1000 hours) were also performed to compare degradation between ambient and pressurized operation, although this data was limited. 


\subsection{Literature Review of the Effect of Pressure on SOFC Performance}

A brief summary of key observations from literature reviewed regarding SOFC performance is provided. In general, studies have shown benefits of pressure beyond nernst potential increases including reduction of anode and cathode activation as well as anode concentration polarizations.

“Parametric study of solid oxide fuel cell performance" $\mathrm{Ni}$, Leung, Leung1

This was a modeling study with comparisons to data in the literature.

\section{Concentration Polarization}

- Two parts, molecular and Knudsen diffusion

- Knudsen - If pore size is much smaller than the mean free path of the species, the molecule-pore wall interaction dominates

- Pore size is larger than mean free path - molecular dominates

- Pressure impact dependent on geometry and relative Knudsen/Molecular contributions

Activation Polarization

- Reduces with increased pressure due to higher molar concentration at triple point boundaries (TPBs)

Pore Size/porosity

- Concentration polarization decreases with increasing pore size up to 10 microns

- Optimal pore size of about 3 microns with $40 \%$ porosity

"On the mechanisms and behavior of coal syngas transport and reaction within the anode of a solid oxide fuel cell", Gemmen, Trembly ${ }^{2}$.

- $\quad$ Syngas compositions, $30 \%$ or less $\mathrm{H}_{2}, 30-60 \% \mathrm{CO}$

- $2 \mathrm{~mm}$ thick anode

- Tortuosity $=3.6$

- Porosity $=56 \%$

- Pore diameter = 1 micron

\footnotetext{
1 "Parametric study of solid oxide fuel cell performance", Meng Ni, Michael K.H. Leung *, Dennis Y.C. Leung, Department of Mechanical Engineering, The University of Hong Kong, 7/F Haking Wong Building, Pokfulam Road, Hong Kong, China, Energy Conversion and Management 48 (2007) 1525-1535, Received 17 May 2006; accepted 26 November 2006

2 "On the mechanisms and behavior of coal syngas transport and reaction within the anode of a solid oxide fuel cell”, R.S. Gemmen, J. Trembly, National Energy Technology Laboratory, Journal of Power Sources 161 (2006) 1084-1095, Received in revised form 23 May 2006; accepted 6 June 2006
} 


\section{Concentration Polarization}

- Concentration polarization reaches a minimum at 5 atmospheres for due to increased $\mathrm{H}_{2}$ production

- As pressure increases, $\mathrm{H}_{2}$ generation increases due to steam methane reforming (SMR) and water gas shift (WGS) reactions up to $7 \mathrm{~atm}$

- At 8 atm and above methane is produced

"Characteristics of anodic polarization of solid oxide fuel cells under pressurized conditions", Kikuchia, Yanoa, Takeguchib, Eguchia ${ }^{3}$

Experimental study was performed using anode symmetrical cell test setup.

\section{Concentration Polarization}

- $\quad$ Anode symmetric cell Ni-YSZ/YSZ/Ni-YSZ

- Anodic polarization increases with increasing pressure, decreases with increased $\mathrm{P}_{\mathrm{O} 2}$ at interface.

\section{"Electrode Studies at High Pressure", Pederson, McCarthy, Chou, Coffey, Coyle, Marina, Nguyen, Thomsen, and Zhou ${ }^{4}$}

Experimental and analytical study was performed on cathode symmetric cells with focus on effect of $\mathrm{P}_{\mathrm{O} 2}$ on different cathodes up to 100 Bara.

Concentration Polarization

- Exchange current density followed $\mathrm{P}\left(\mathrm{O}_{2}\right)^{1 / 2}$ dependence for LSM-20, Au

- LSM/Ceria and LSF show lesser dependence

"Oxygen electrode reaction on stabilized zirconia under high oxygen pressure (up to 100 bar)", Drevet, He'nault, Fouletier ${ }^{5}$

Three electrodes were studied-Pt, Ag, LSM35

- $\mathrm{Pt}-\mathrm{Po} 2$ negative effect

- Ag - initial slightly decrease than increase greatly for Po2 higher than 30bar

- LSM35 showed Rp decreases up to $\mathrm{P}_{\mathrm{O} 2}<20$ bar

\footnotetext{
3 "Characteristics of anodic polarization of solid oxide fuel cells under pressurized conditions", Ryuji Kikuchia, Tatsuya Yanoa, Tatsuya Takeguchib, Koichi Eguchia, Solid State Ionics 174 (2004) 111 -117, Received 5 February 2004; accepted 29 May 2004

4 "Electrode Studies at High Pressure", Larry Pederson, Ben McCarthy, Matt Chou, Greg Coffey, Chris Coyle, Olga Marina, Carolyn Nguyen, Ed Thomsen, and Xiao-Dong Zhou, 8th Annual SECA Workshop, San Antonio TX, August 7-9, 2007

5 "Oxygen electrode reaction on stabilized zirconia under high oxygen pressure (up to 100 bar)", C. Drevet, M. He'nault, J. Fouletier, Solid State Ionics 136-137 (2000) 807-812
} 


\subsection{Test Apparatus}

Testing was performed on button cells and full fuel cells, both at atmospheric and pressurized conditions. The combination of cathode button cell and full cell testing is used to deconvolve performance of the whole cell. RRFCS has capabilities to test at system relevant conditions including pressure, temperature, and the full range of anode compositions experienced in service.

\section{Pressurized Button Cell Apparatus}

As part of this program, RRFCS has developed the capability to test cathode symmetric button cells at pressures up to 7 Bara and temperatures up to $1000^{\circ} \mathrm{C}$ under various gas compositions consisting of $\mathrm{O}_{2}, \mathrm{~N}_{2}, \mathrm{CO}_{2}$, and steam.

The pressurized button cell test stand was designed and built on this program and is shown below in Figure 3.1. The test specimen is placed on a pedestal tube in the middle of the fixture which is then enclosed with a closed-one-end alumina tube which forms the pressure boundary. An inconel guard tube is placed around the alumina tube for safety. This assembly is placed inside of a furnace which heats the sample up to test temperature. The alumina tube is pressed onto a fixed base plate and is sealed on the bottom edge by means of a compressible gasket. Load is transferred to the alumina tube from compression springs and a loading plate through a load transfer insulation block. Additional personnel shields are placed around the fixture in case of a pressure boundary failure.

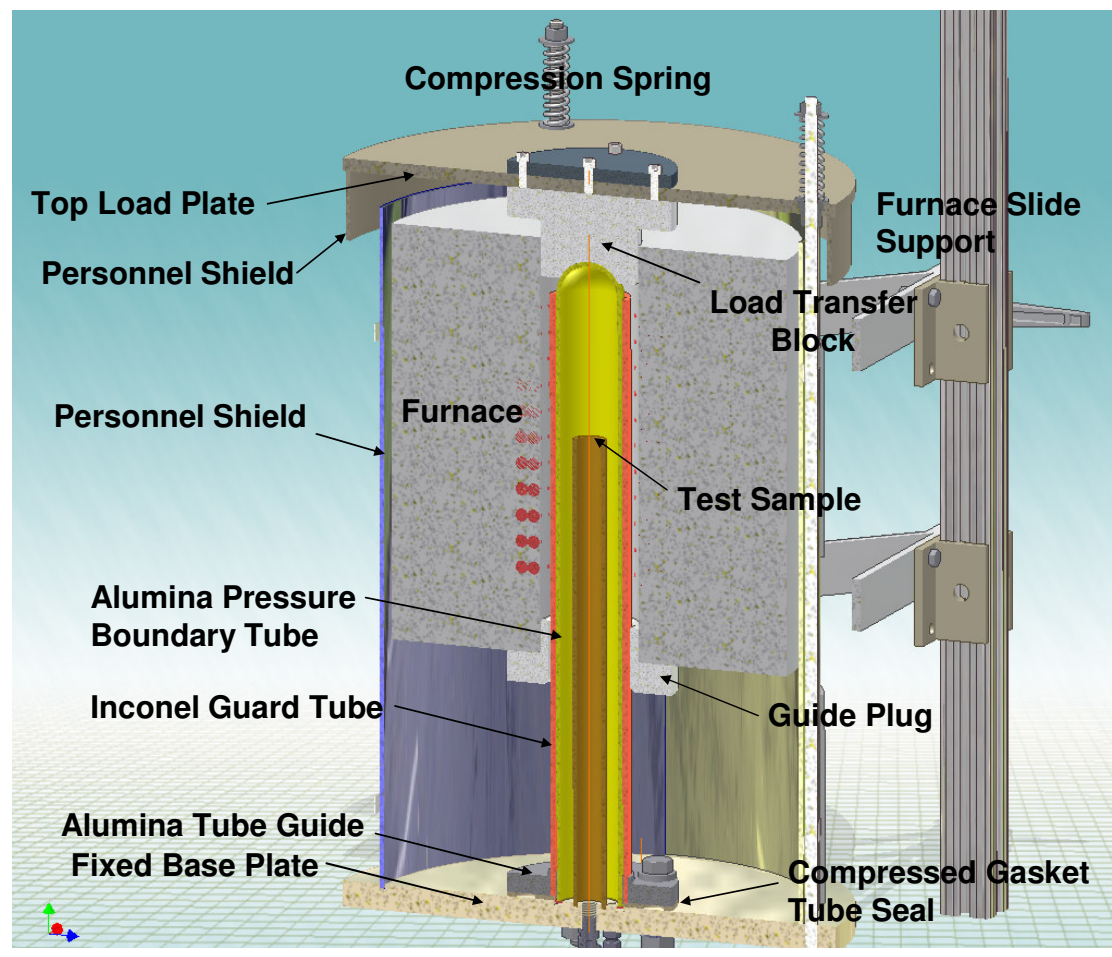

Figure 3.1 - Pressurized Button Cell Apparatus 
The test setup - including the gas supply system, power control, and safety system which were developed separate from this program - is shown in the picture in Figure 3.2. The test arrangement is assembled and the test furnace lowered over the sample before adding seal load and personnel shield components. The test stand is supplied with gases including Air, $\mathrm{N}_{2}, \mathrm{CO}_{2}$, by a calibrated mixing station. Steam is added as required through a heated humidifier column, the effluent kept warm by means of a heated supply line. Data is collected for long-term tests with an automated DAS. EIS measurements were carried out using a Solartron 1286 or 1287 potentiostat with a Solartron 1255 frequency response analyzer. The applied frequency range was from $0.01 \mathrm{~Hz}$ to $150 \mathrm{kHz}$, with data collected by scanning from high to low frequencies. Polarization amplitude of $20 \mathrm{mV}$ was applied at the open-circuit voltage (OCV) condition. Polarization value was obtained by dividing the difference of ASR and ohmic resistance by 2 . A ventilated exhaust duct extracts the gases exiting the test stand. A safety system automatically shuts down the power to the test stand if there is an overtemperature or an electrical short detected.

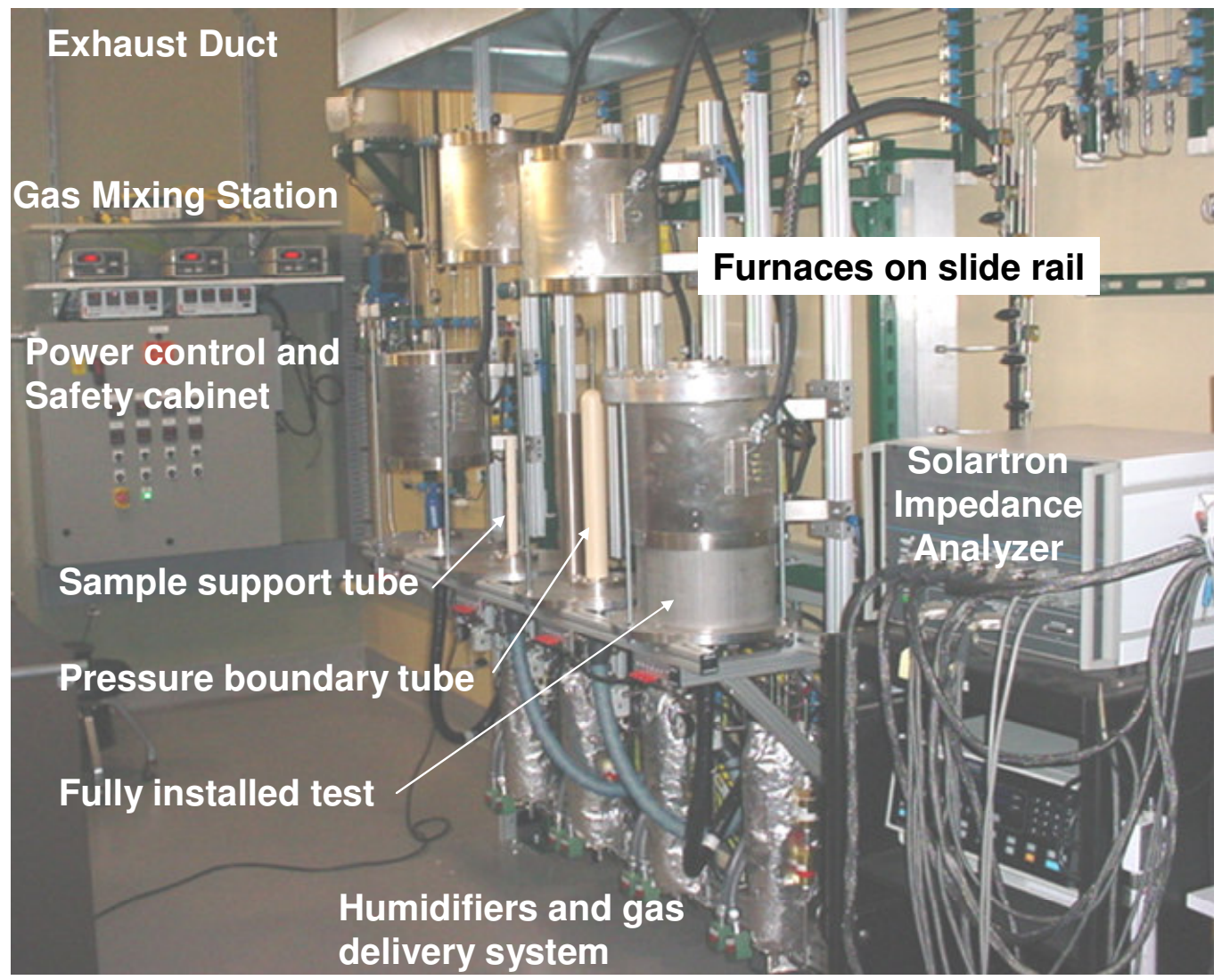

Figure 3.2 - Pressurized Button Cell Test Setup

\section{Fuel Cell Tests}

Testing on fuel cell substrates was performed in both atmospheric and pressurized test stands. Five pressurized test stands are located in two separate ventilated enclosures, one of which is shown in Figure 3.3 below. Each test stand has a gas mixing station which blends air, $\mathrm{N}_{2}$, and $\mathrm{CO}_{2}$ on the cathode and $\mathrm{H}_{2}, \mathrm{CO}_{2}$, and $\mathrm{N}_{2}$ on the anode. The streams can be passed through a heated humidification column to add steam on both 
the anode and cathode. The blends can simulate the full range of anode and cathode conditions from inlet to outlet.

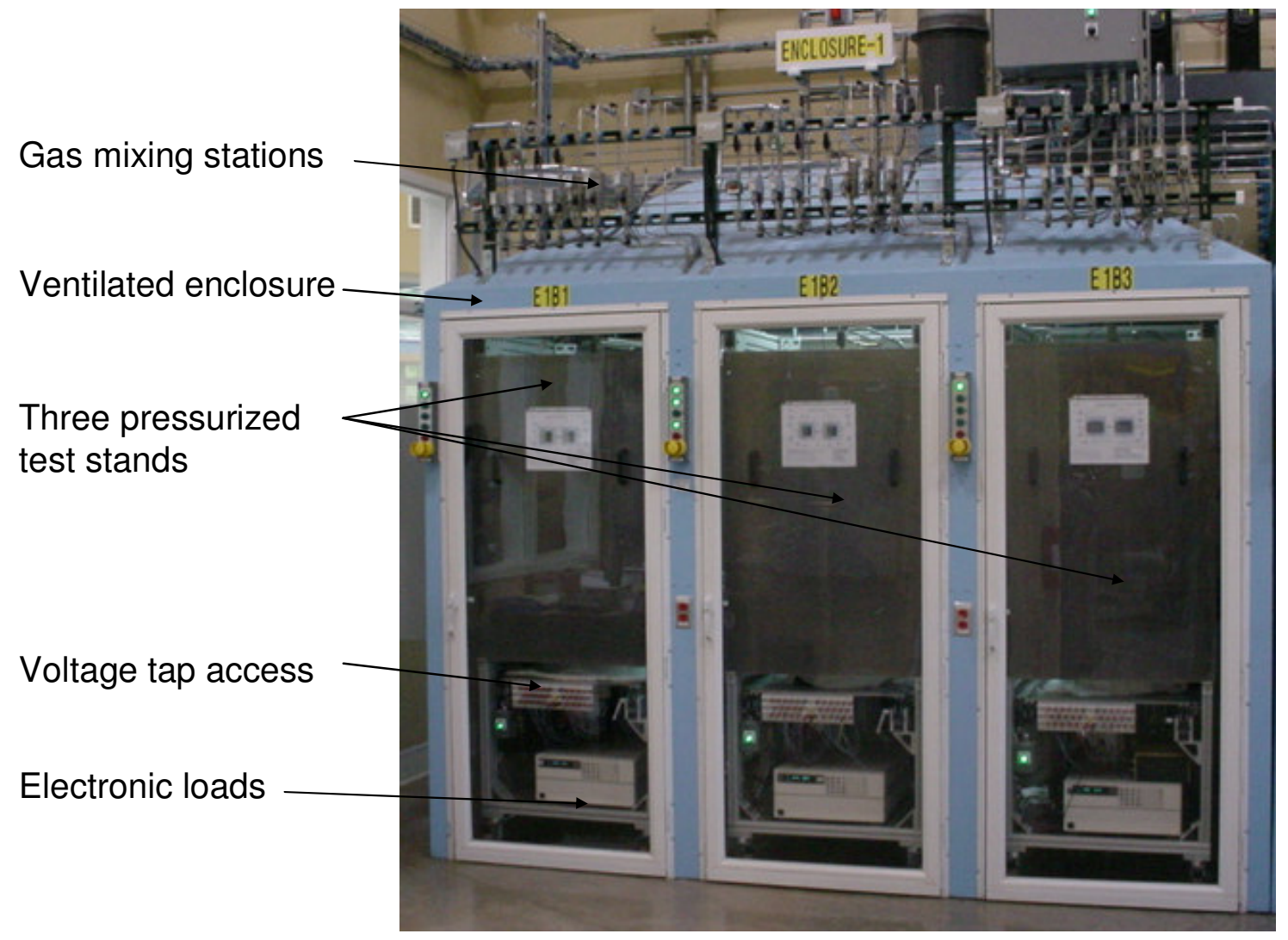

Figure 3. 3 - Pressurized Test Stands in Ventilated Enclosure

The pressurized test stand arrangement is shown in Figures 3.4 and 3.5. Figure 3.4 shows the test rig consists of a hot-walled pressure vessel which sits inside a 3-zone furnace to control the temperature boundary condition of the test sample. The seal region is kept outside of the hot zone to permit the use of standard seal materials.

Process connections for incoming anode and cathode streams are made at a fixed lower head, along with electrical and instrumentation lead outs. The electronic load which sets the steady state current condition is located in this region also. In addition, an external voltage tap patch panel is available for connecting a Solartron to acquire EIS data.

In Figure 3.5 we see the internals of the test section after the pressure vessel is removed. The lower section has a concentric anode and cathode gas preheat coil to bring the incoming gases to process temperature. The test sample sits inside the test chamber housing where two fuel cells connect to the fuel manifold and the cathode gas is directed over the samples. Above the test chamber the anode exhaust is routed and combined with the cathode exhaust to combust the unused fuel in a flare section before exiting the pressure vessel. The exhaust then flows out the top of the pressure vessel, passing through a cooling coil before venting into the enclosure. 


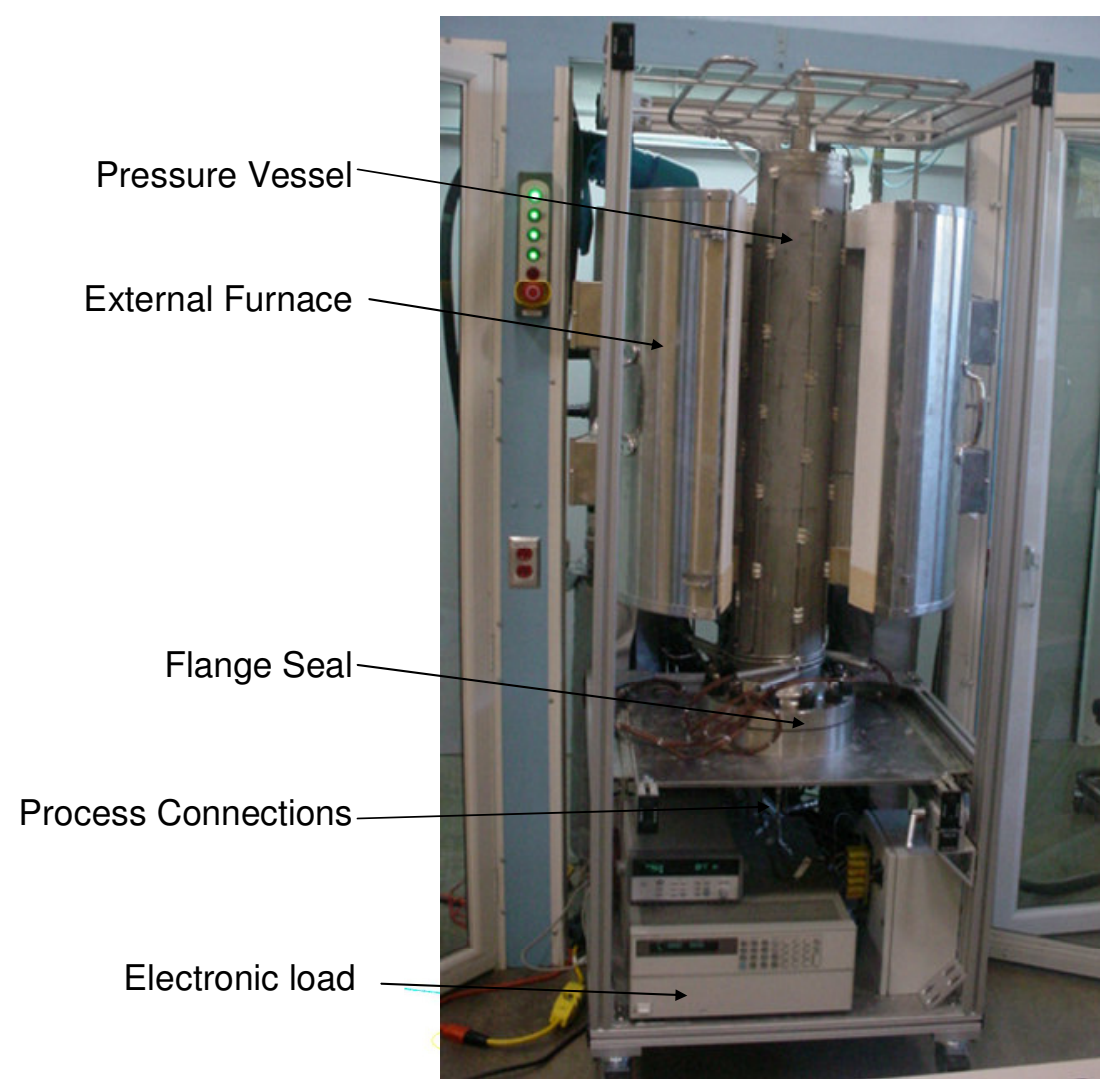

Figure 3. 4 - Pressurized Test Stand Showing Pressure Vessel

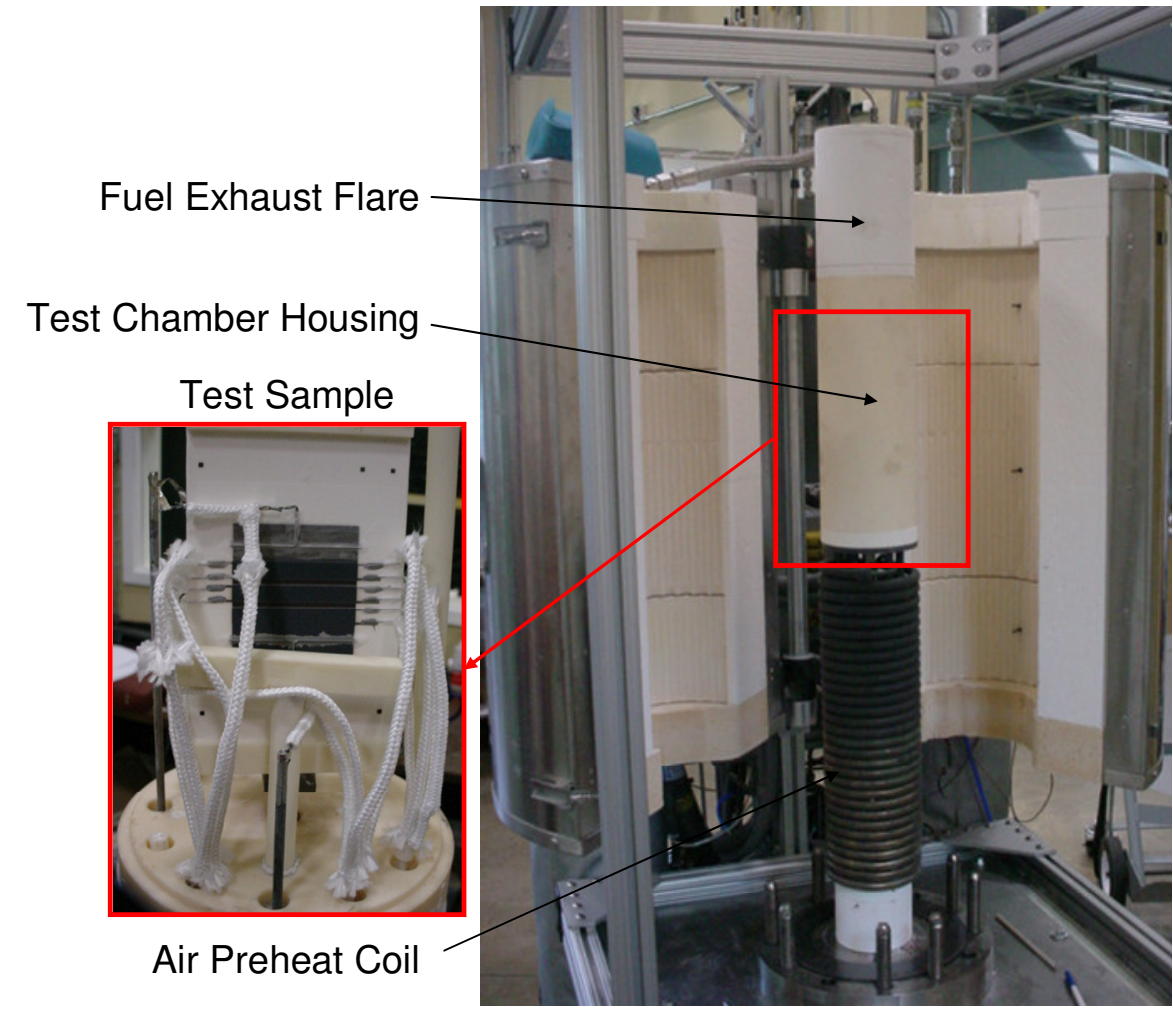

Figure 3. 5 - Pressurized Test Setup with Vessel Removed 
The samples tested were triple cells as shown in Figure 3.6. The samples consist of 3 cells with two cell primary interconnects (PICs). Fuel flows into the two cells by means of a manifold into which the two samples are connected, and exhausts into the flare section above through an exhaust tube. The cathode gas is directed over the face of the samples by means of a manifold nozzle. Voltages taps on the anode and cathode layers are used to measure the voltages at various points so as to separate out losses from the cells, cell interconnects, and the current collector layers. Current flows through the samples by means of the secondary interconnect wire (SIC) which connects to the current bus bars.

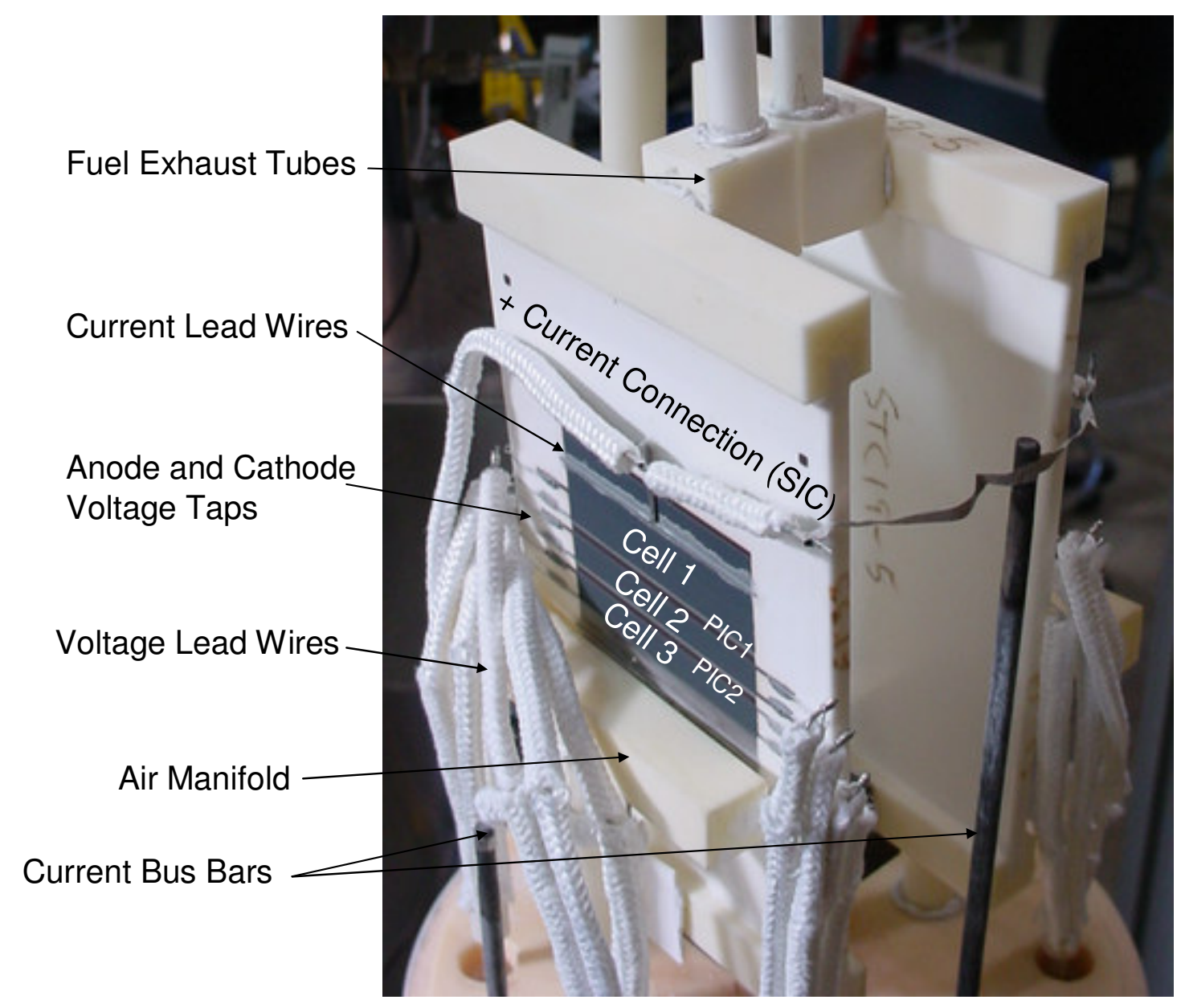

Figure 3.6 - Triple Cell Test Sample

The atmospheric stands used have similar functionality and are simpler in design than the pressurized test stands described above, so they are not detailed here. 


\subsection{Button Cell Testing}

The button cells tested were cathode symmetric cells made of a screen printed cathode composed of LSM + YSZ and cathode current collector composed of LSM. A platinum mesh is attached to the CCC layer with additional LSM ink. Using the apparatus described above in Section 3, a sequence of tests was performed to examine the effect of composition, pressure, and temperature on cathode performance. The matrix of test conditions is shown below in Table 3.1.

Pressurized BC Test Matrix

Pressure Temp Composition

\begin{tabular}{|c|c|c|c|c|c|c|c|c|}
\hline Test & Purpose & Bara & $\stackrel{\circ}{ } \mathbf{C}$ & $\mathbf{N}_{2}$ & $\mathrm{O}_{2}$ & $\mathrm{H}_{2} \mathrm{O}$ & $\mathrm{CO}_{2}$ & Range \\
\hline $1 \mathrm{~A}$ & \multirow{4}{*}{ Effect of Pressure } & Varies & 800 & $88 \%$ & $12 \%$ & $0 \%$ & $0 \%$ & 1 to 6.4 Bara \\
\hline 1B & & Varies & 800 & $85 \%$ & $12 \%$ & $3 \%$ & $0 \%$ & 1 to 6.4 Bara \\
\hline $2 A$ & & Varies & 900 & $88 \%$ & $12 \%$ & $0 \%$ & $0 \%$ & 1 to 6.4 Bara \\
\hline 2B & & Varies & 900 & $85 \%$ & $12 \%$ & $3 \%$ & $0 \%$ & 1 to 6.4 Bara \\
\hline 3A & \multirow{2}{*}{ Effect of Temperature } & 6.4 & Varies & $88 \%$ & $12 \%$ & $0 \%$ & $0 \%$ & $750-950^{\circ} \mathrm{C}$ \\
\hline 3B & & 6.4 & Varies & $85 \%$ & $12 \%$ & $3 \%$ & $0 \%$ & $750-950^{\circ} \mathrm{C}$ \\
\hline 4A & $\mathrm{H}_{2} \mathrm{O}$ Test & 1 & 850 & Varies & $12 \%$ & Varies & $0 \%$ & $0-26 \%$ \\
\hline 4B & Constant $\mathbf{P}_{\mathrm{H} 2 \mathrm{O}}$ Test & Varies & 850 & Varies & $12 \%$ & Varies & $0 \%$ & $\mathrm{P}_{\mathrm{H} 2 \mathrm{O}}=0.2 \mathrm{Bar}$ \\
\hline $5 A$ & \multirow{4}{*}{$\mathrm{O}_{2}$ Variation } & 1 & 800 & $80 \%$ & Varies & $0 \%$ & $0 \%$ & $8-20 \%$ \\
\hline $5 B$ & & 6.4 & 800 & $80 \%$ & Varies & $0 \%$ & $0 \%$ & $8-20 \%$ \\
\hline $5 \mathrm{C}$ & & 1 & 925 & $80 \%$ & Varies & $0 \%$ & $0 \%$ & $8-20 \%$ \\
\hline 5D & & 6.4 & 925 & $80 \%$ & Varies & $0 \%$ & $0 \%$ & $8-20 \%$ \\
\hline 6 & co Tost & 61 & 850 & 0.0/ & & $0 \%$ & Yoris & 0 25\% \\
\hline 0 & $\mathrm{CO}_{2}$ Iest & 6.4 & 850 & $88 \%$ & $12 \%$ & $0 \%$ & Varies & $0-25 \%$ \\
\hline \multirow{4}{*}{7} & \multirow{4}{*}{500 hours degradation } & 1bara & & $88 \%$ & $12 \%$ & $0 \%$ & $0 \%$ & \\
\hline & & 1 bara & & $85 \%$ & $12 \%$ & $3 \%$ & $0 \%$ & \\
\hline & & 6.4bara & & $88 \%$ & $12 \%$ & $0 \%$ & $0 \%$ & \\
\hline & & 6.4bara & & $85 \%$ & $12 \%$ & $3 \%$ & $0 \%$ & \\
\hline
\end{tabular}

Table 4. 1 Matrix of Test Conditions for Pressurized Button Cell Tests

\section{Effect of Pressure}

Figures 4.1 through 4.3 show the impact of pressure on the total cathode polarization (Rp) with a $12 \% \mathrm{O}_{2}$ feed at two temperatures. Figure 1 is at $800^{\circ} \mathrm{C}$ and Figure 2 is at $900^{\circ} \mathrm{C}$. At $800^{\circ} \mathrm{C}$, the cathode polarization is dominated by the activation loss, which is the higher frequency arc to the left of the $x$-axis. There is an approximate $40 \%$ reduction in the polarization with the increase in pressure from 1 to $6.4 \mathrm{Bara}$, although the majority of that reduction takes place with the pressure increase from 1 to 3 Bara. At $900^{\circ} \mathrm{C}$ the activation polarization similarly shows an approximate $40 \%$ reduction in overall polarization going from 1 to 6.4 Bara. There were two arcs in impedance spectra for the cathode symmetrical cells in which the high frequency arc was reduced with increased pressure but the low frequency arc (to the right of the $x$-axis) was nearly pressure independent. The effect of $3 \%$ steam on performance was negligible. 

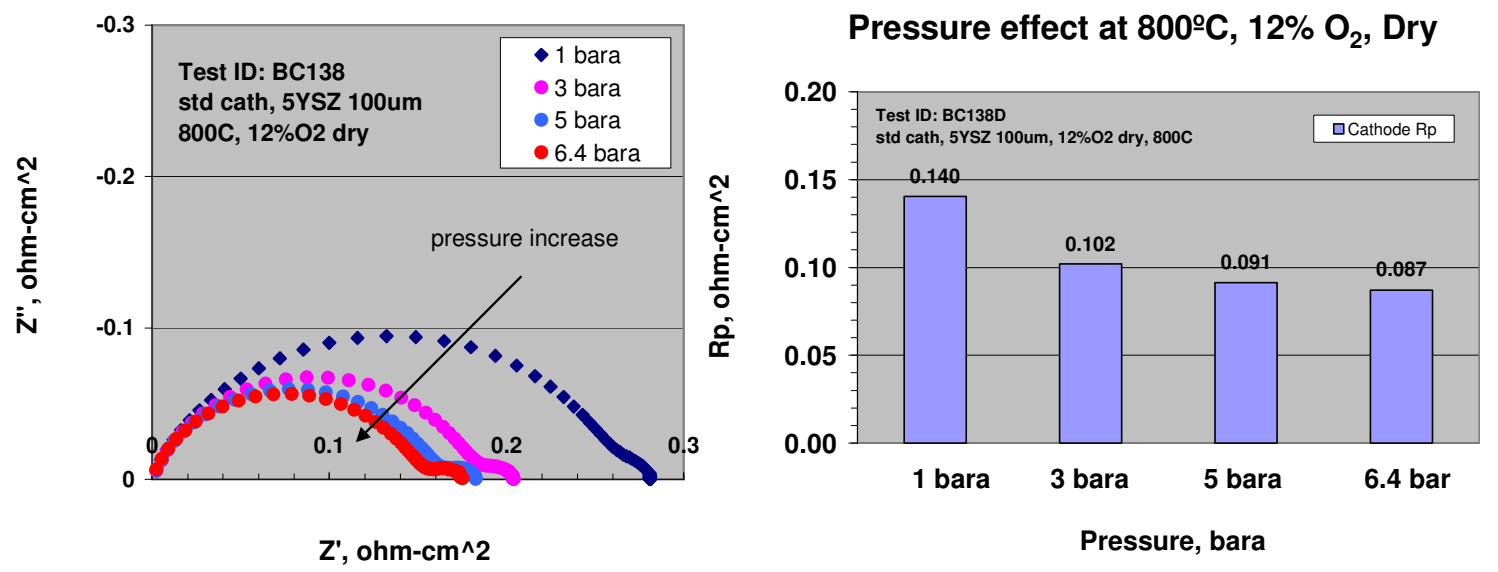

Figure 4.1 Effect of Pressure on Cathode Polarization at $800^{\circ} \mathrm{C}$ and $12 \% \mathrm{O}_{2}$
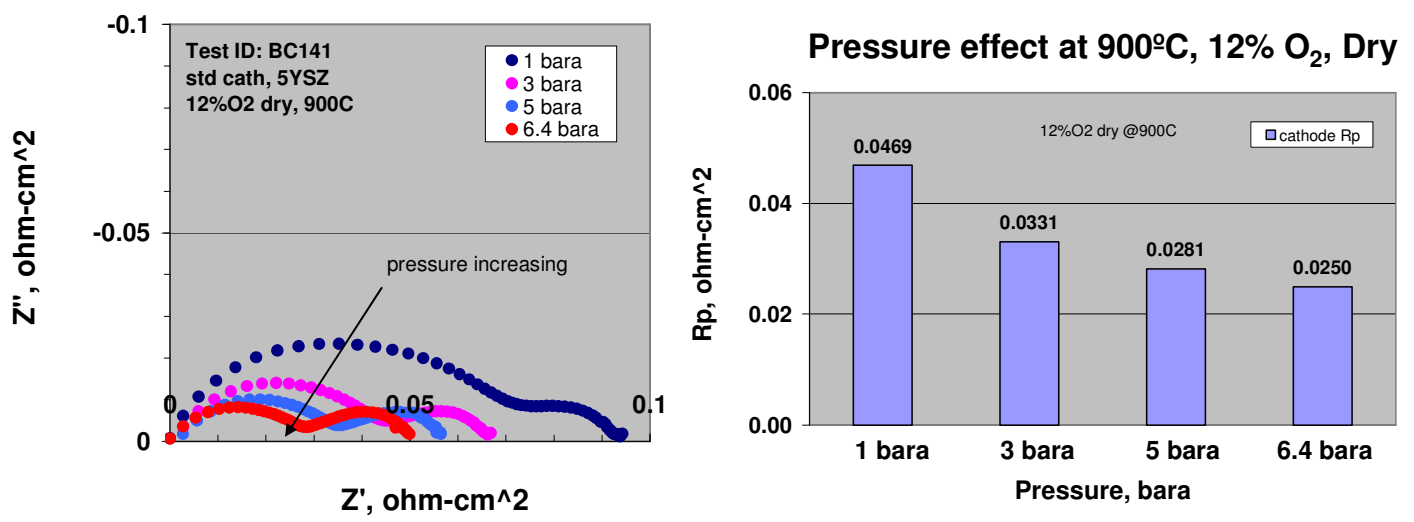

Figure 4.2 Effect of Pressure on Cathode Polarization at $900^{\circ} \mathrm{C}$ and $12 \% \mathrm{O}_{2}$

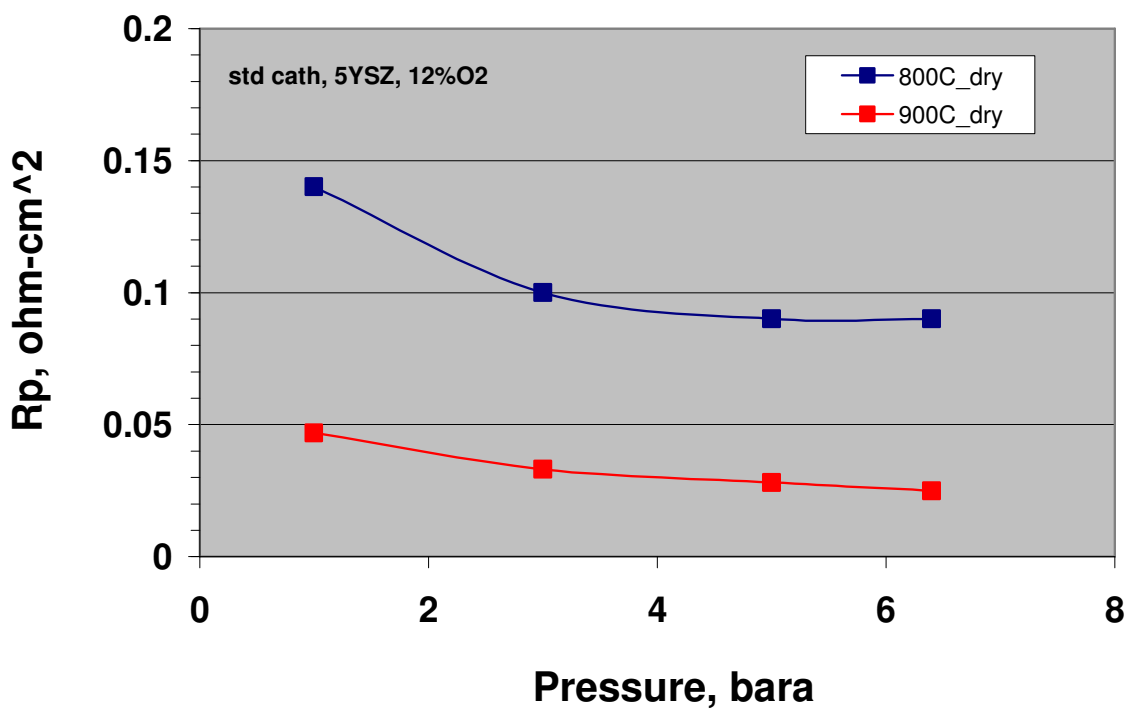

Figure 4.3 Summary of Pressure Effect Data at Two Temperatures. 


\section{Effect of Temperature}

The cathode activation energy, calculated from slope of the Arrhenius plot, is shown in Figure 4.4 for constant $\mathrm{O}_{2}$ concentration at 1 and 6.4 Bara. The data shows a linear activation energy over the temperature range of $750^{\circ} \mathrm{C}$ to $950^{\circ} \mathrm{C}$ and a moderate increase in activation energy with increased pressure.

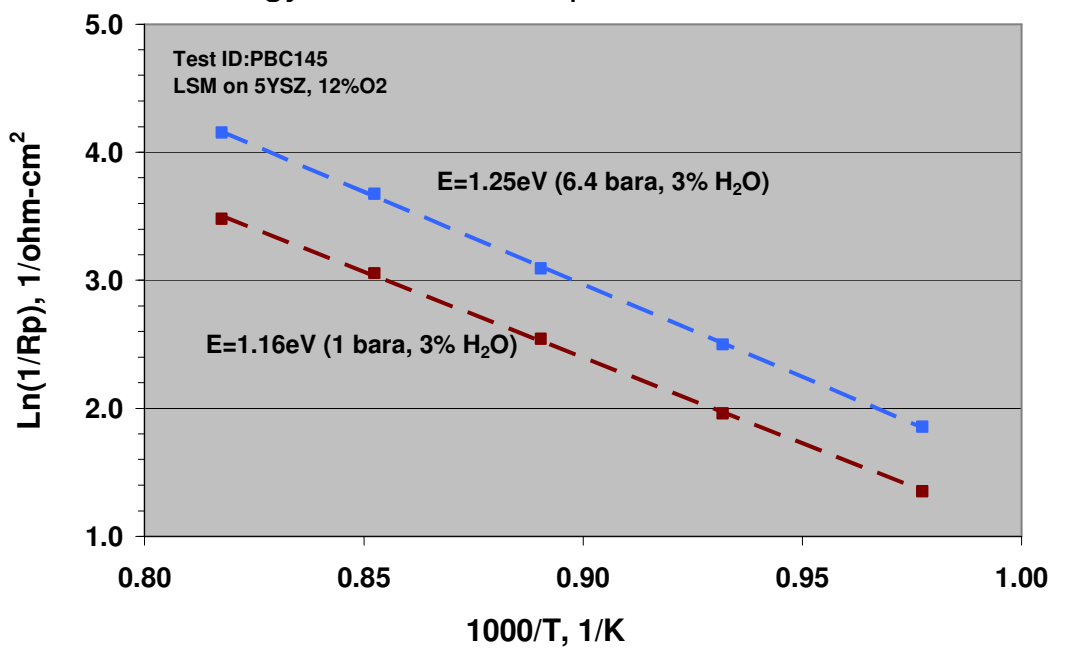

Figure 4.4 Activation Energy at 1 and 6.4 Bara, 12\% 02

This was duplicated at a range of $\mathrm{O}_{2}$ concentrations at 1 and 6.4 Bara on a second sample as shown in Figure 4.5, but only over the range of temperatures from 800 to $900^{\circ} \mathrm{C}$. Activation energy value varies from 1.2 to $1.37 \mathrm{eV}$ at 1 bara and $1.24 \sim 1.47 \mathrm{eV}$ at 6.4 bara. Oxygen reduction reaction is strongly affected by surface adsorption step and then activation energy could be related to oxygen partial pressure effect on surface properties. The data demonstrates that activation energy shows a dependence upon $\% \mathrm{O}_{2}$ and $\mathrm{P}_{\mathrm{O} 2}$ independently, with $\% \mathrm{O}_{2}$ being more dominant. This suggests that the simple dependence of current exchange density as a function of $\mathrm{P}_{\mathrm{O} 2}$ alone is insufficient to describe the behavior. 


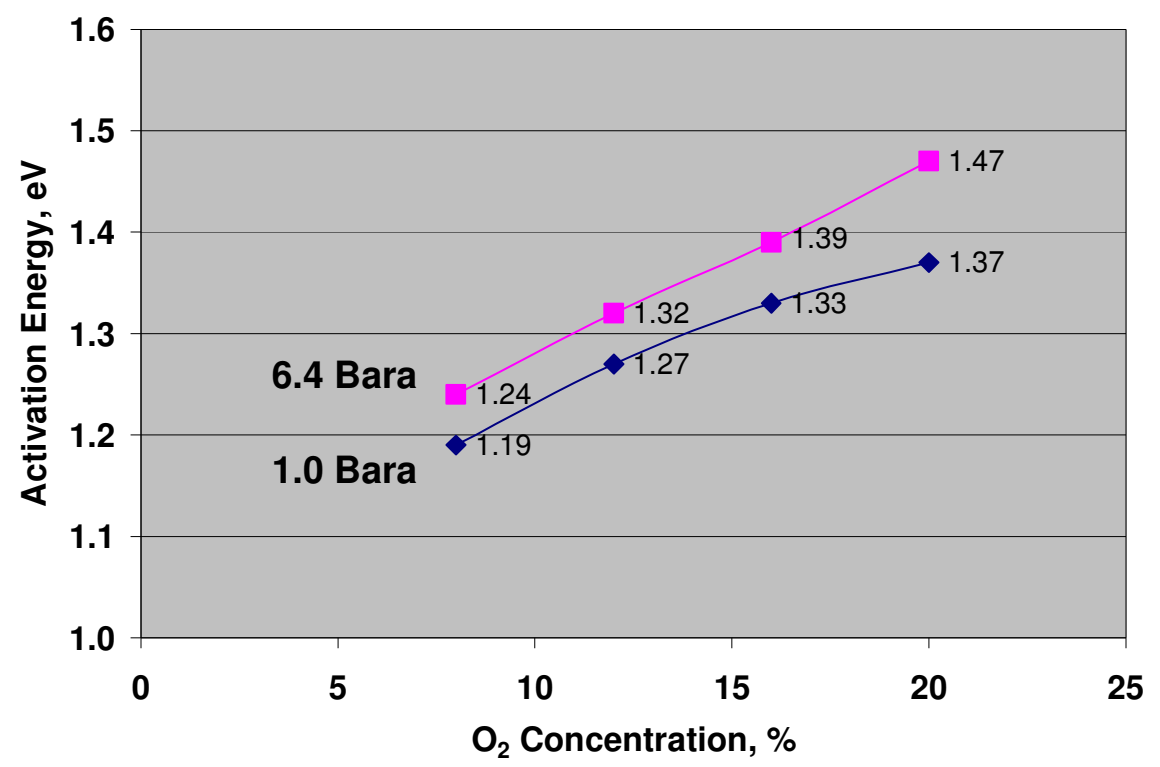

Figure 4.5 Effect of Pressure and Oxygen Concentration on Activation Energy

\section{Effect of $\mathrm{O}_{2}$ Concentration}

The effect of $\mathrm{O}_{2}$ concentration on cathode $\mathrm{Rp}$ was investigated at different pressure (6.4 and 1 bara ) and temperature $\left(800,850\right.$, and $\left.900^{\circ} \mathrm{C}\right)$. Rp varies from $0.016 \mathrm{ohm}-\mathrm{cm}^{2}$ at 6.4 bara and $900^{\circ} \mathrm{C}$ to 0.176 at 1.0 Bara and $800^{\circ} \mathrm{C}$. The data is summarized in Figures 4.6 through 4.8 .

The impedance data at 6.4 Bara and $900^{\circ} \mathrm{C}$ is shown in Figure 4.9. The Rp value was significantly reduced from 1 Bara to 6.4 Bara condition while Rs value remains constant under the pressure change at constant temperature. At constant pressure and temperature, as the oxygen concentration is decreased, both the high and low frequency arcs of EIS increased together. It is anticipated that the first and second arc of EIS could be related to charge transfer reaction, and diffusion mass transport (or some other mass transfer mechanism such as a surface adsorption) respectively. It appears to be reasonable that partial oxygen pressure change gives strong effect on both EIS arcs.

A typical button cell sample is shown in Figure 4.10 which shows a fairly thick layer which includes the cathode and current collector ink used to apply the platinum mesh current collector. The layer is estimated at 225 microns thick on average, with a porosity of $25 \%$ and a tortuosity of 2 . From the impedance data at each condition, the low frequency (diffusion term) was estimated as shown in Figure 4.8. Based on the diffusion model (a more detailed discussion can be found in Section 7.0) for this arrangement we see that the data model indicates the low frequency portion of the impedance data is described by a gas diffusion model through the porous layer. The remaining polarization which composes the high frequency portion of the curve is shown in Figure 4.8. This is considered to be the activation portion of the cathode polarization. 


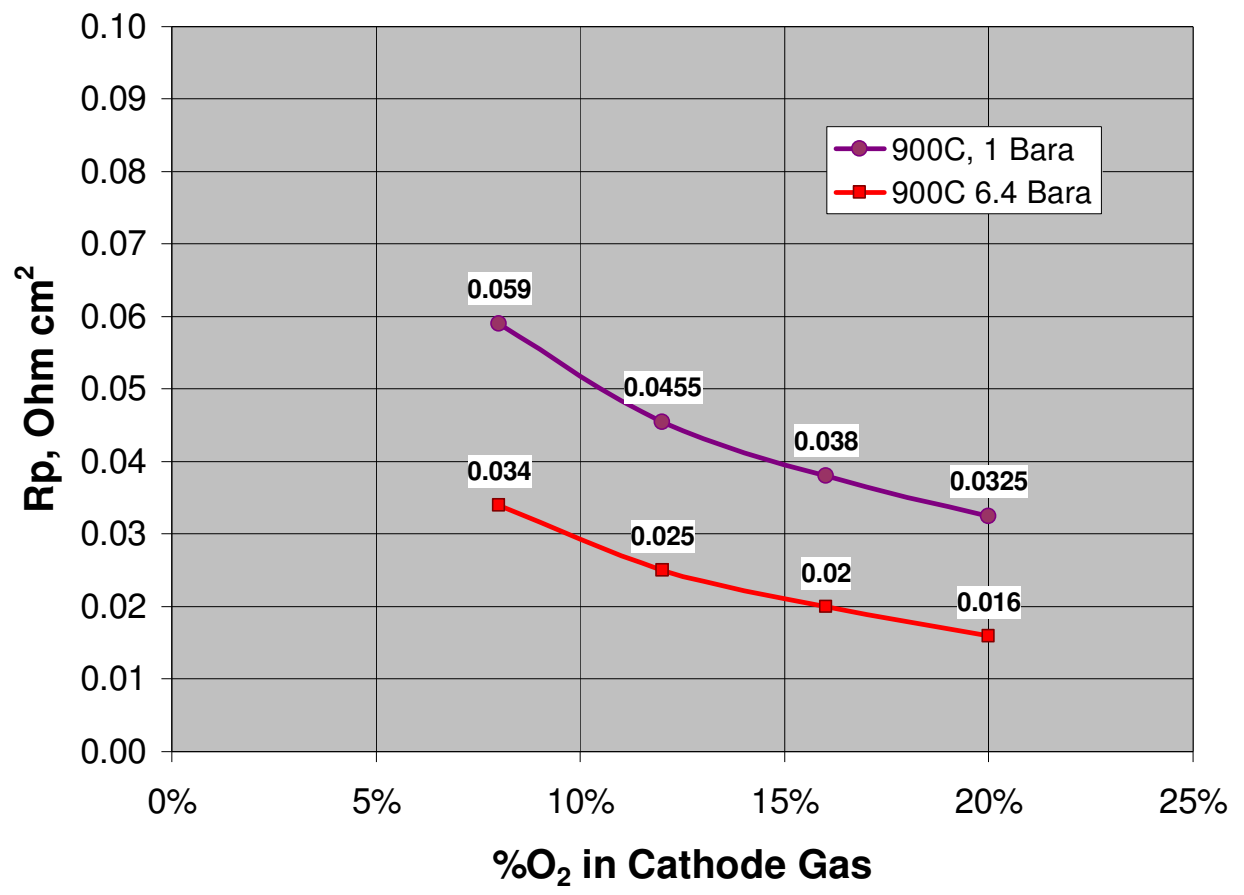

Figure 4.6 Effect of Pressure and $\mathrm{O}_{2}$ Concentration of Cathode $\mathrm{Rp}$ at $900^{\circ} \mathrm{C}$

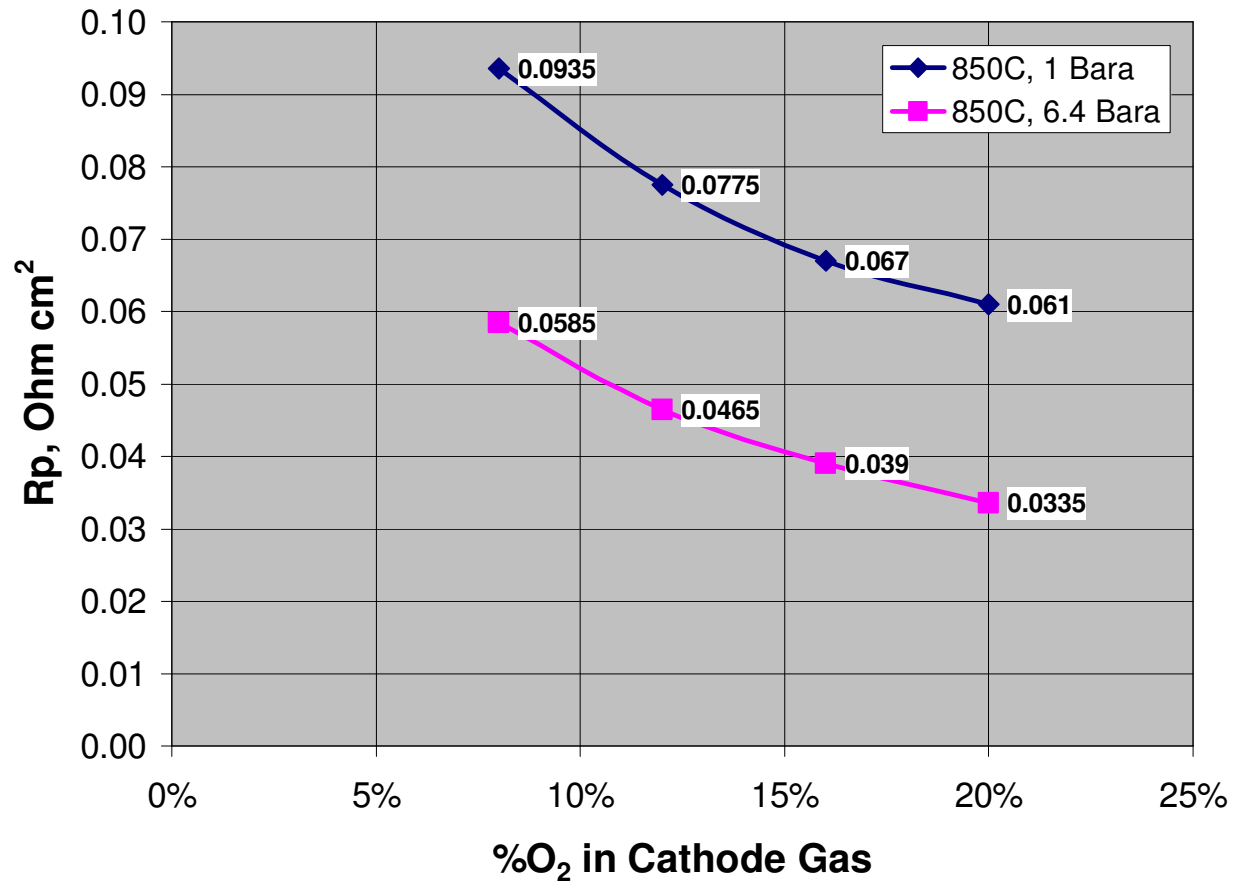

Figure 4.7 Effect of Pressure and $\mathrm{O2}$ Concentration of Cathode Rp at $850^{\circ} \mathrm{C}$ 


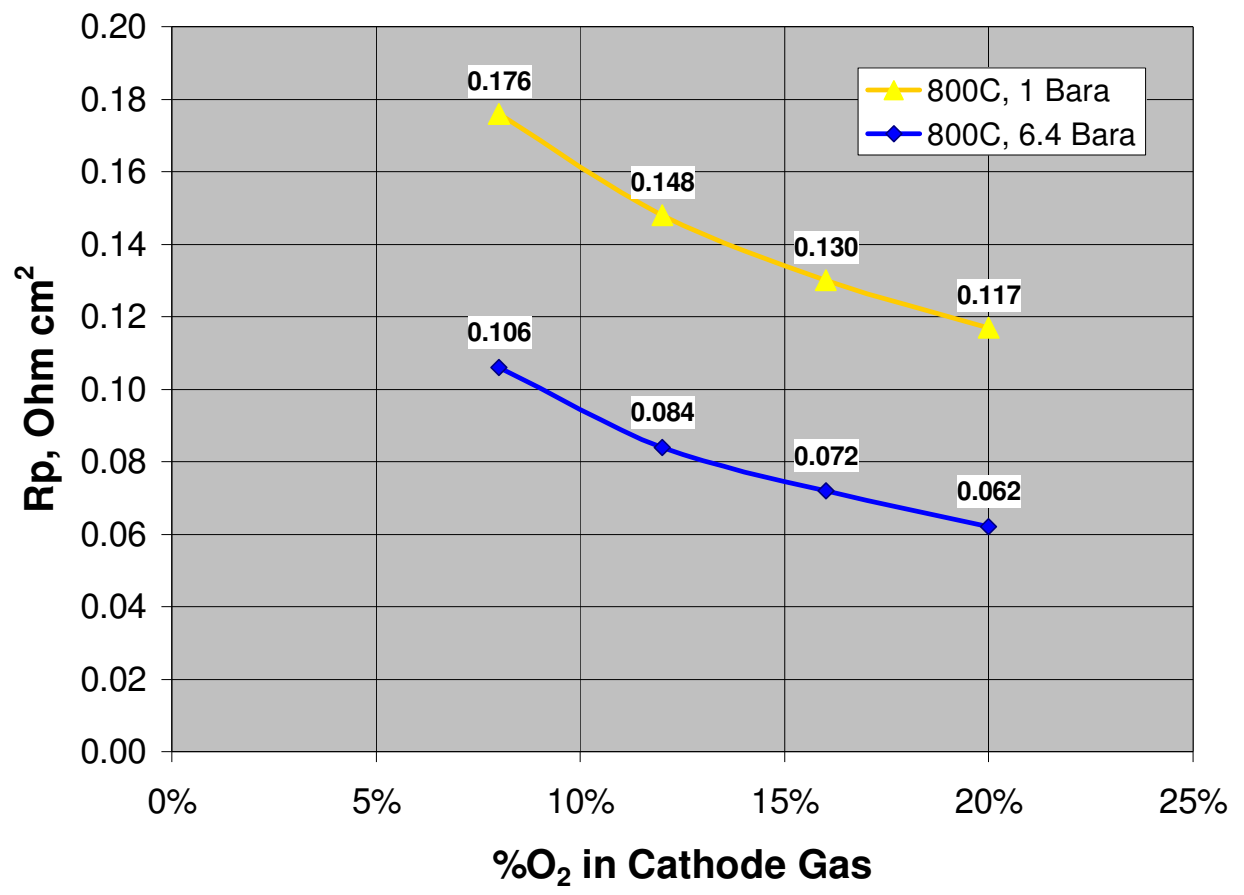

Figure 4.8 Effect of Pressure and $\mathrm{O}_{2}$ Concentration of Cathode $\mathrm{Rp}$ at $800^{\circ} \mathrm{C}$

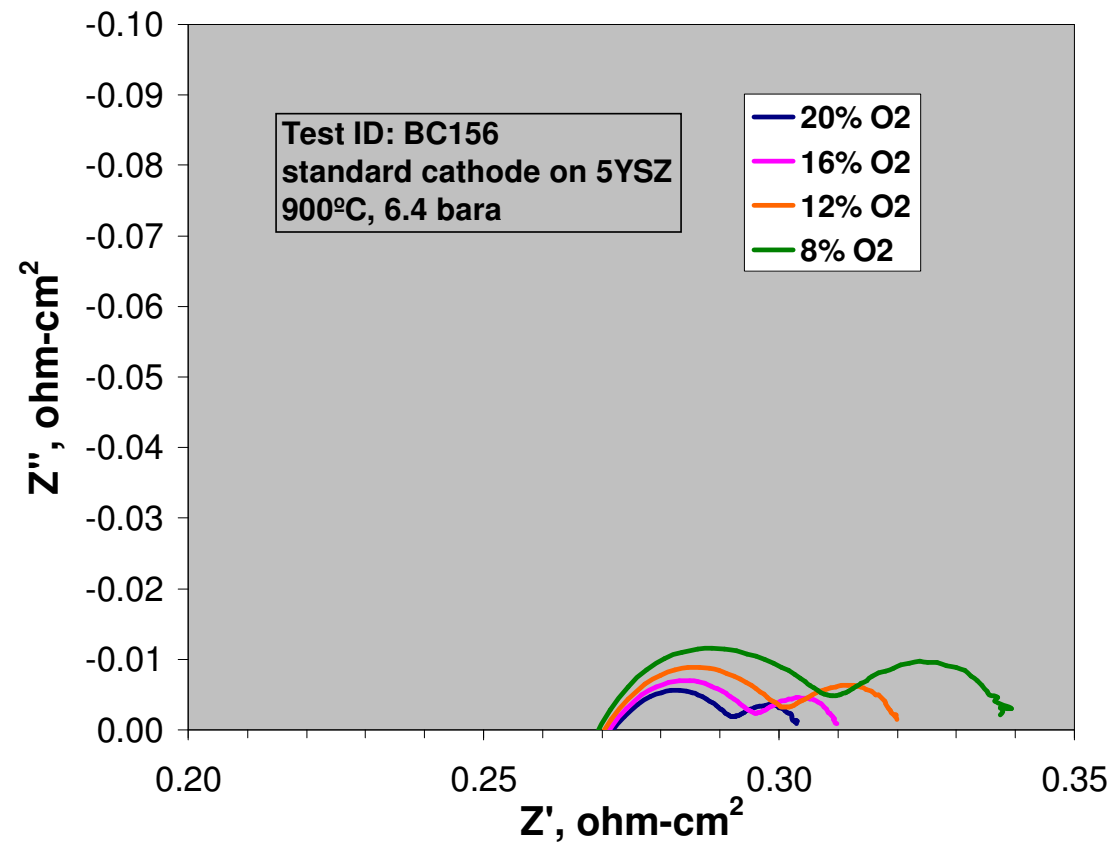

Figure 4.9 Impedance Data from $\mathrm{O}_{2}$ Test Matrix at 6.4 Bara and $900^{\circ} \mathrm{C}$ 


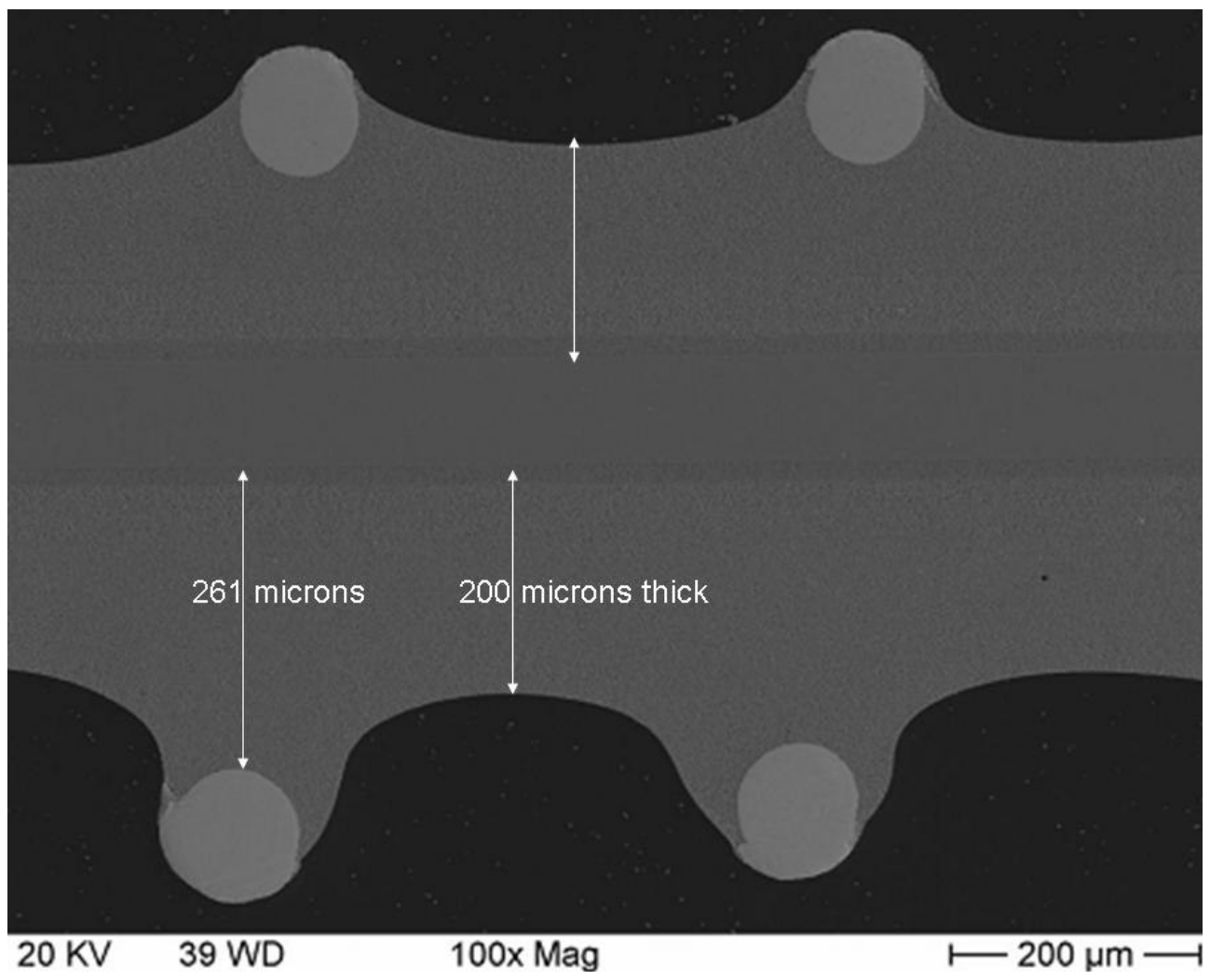

Figure 4.10 Cross-section of typical button cell sample

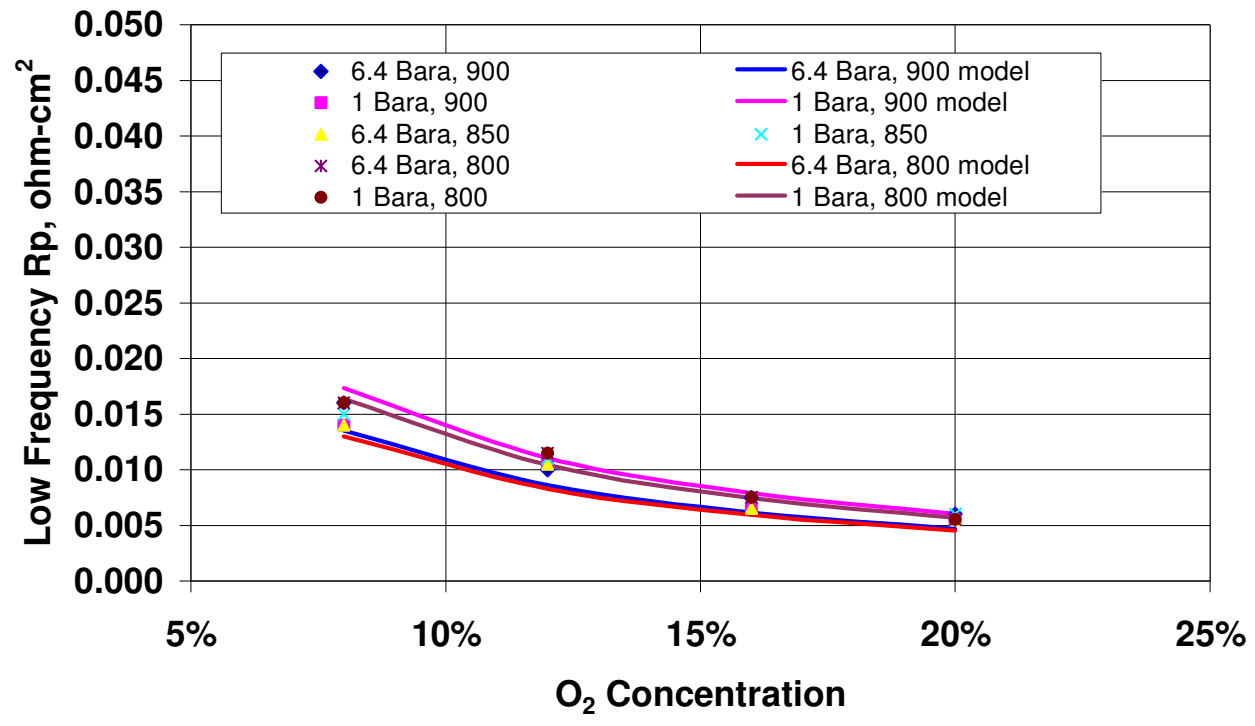

Figure 4.11 Low Frequency (diffusion) Portion of Cathode Polarization 


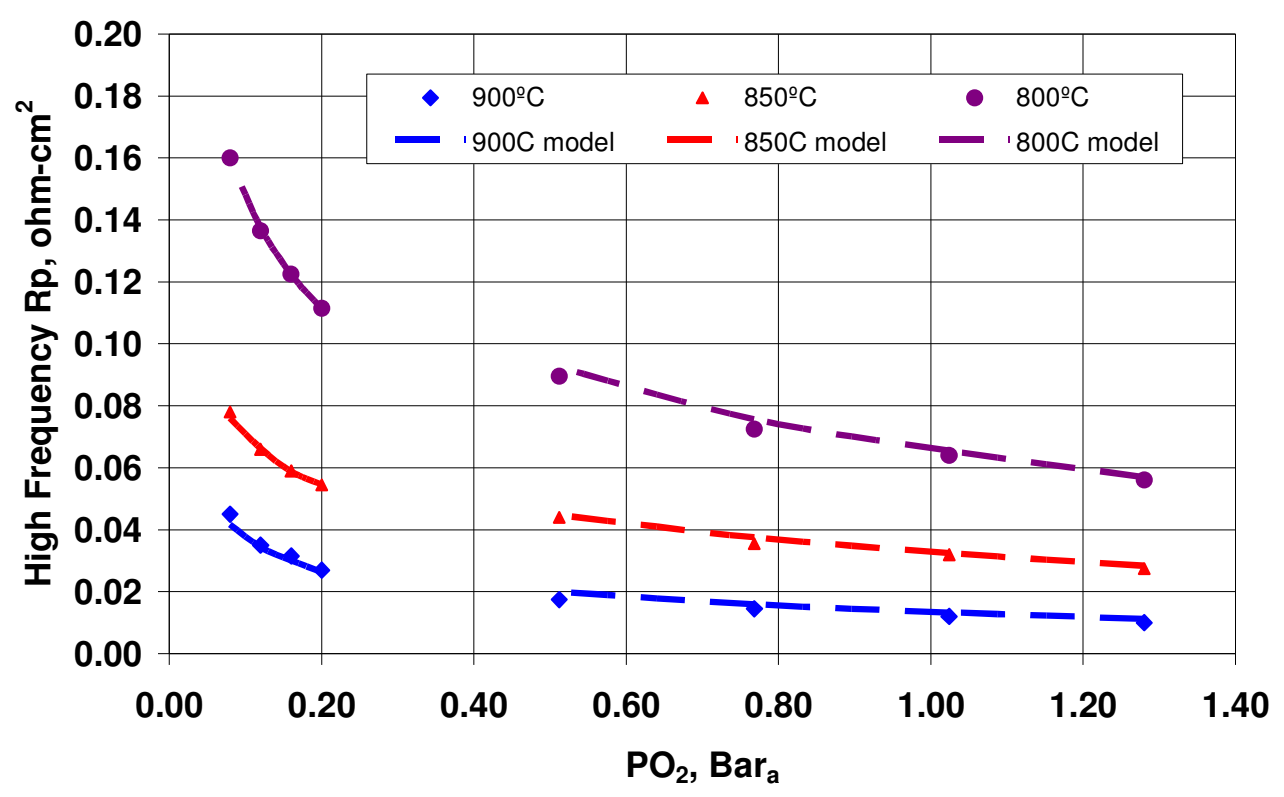

Figure 4.12 High Frequency (activation) Portion of Cathode Polarization

\section{Effect of $\mathrm{CO}_{2}$ Concentration}

CO2 concentration effect $(0,6,18$, and $25 \%)$ on cathode $\mathrm{Rp}$ at 6.4 bara and $850^{\circ} \mathrm{C}$ was investigated. Oxygen concentration was fixed at $12 \%$. Even though there was small Rp increment $\left(0.0015 \mathrm{ohm}-\mathrm{cm}^{2}\right)$ for the presence of $\mathrm{CO}_{2}$, the $\mathrm{CO}_{2}$ concentration effect from $6 \%$ to $25 \%-\mathrm{CO} 2$ was almost negligible.

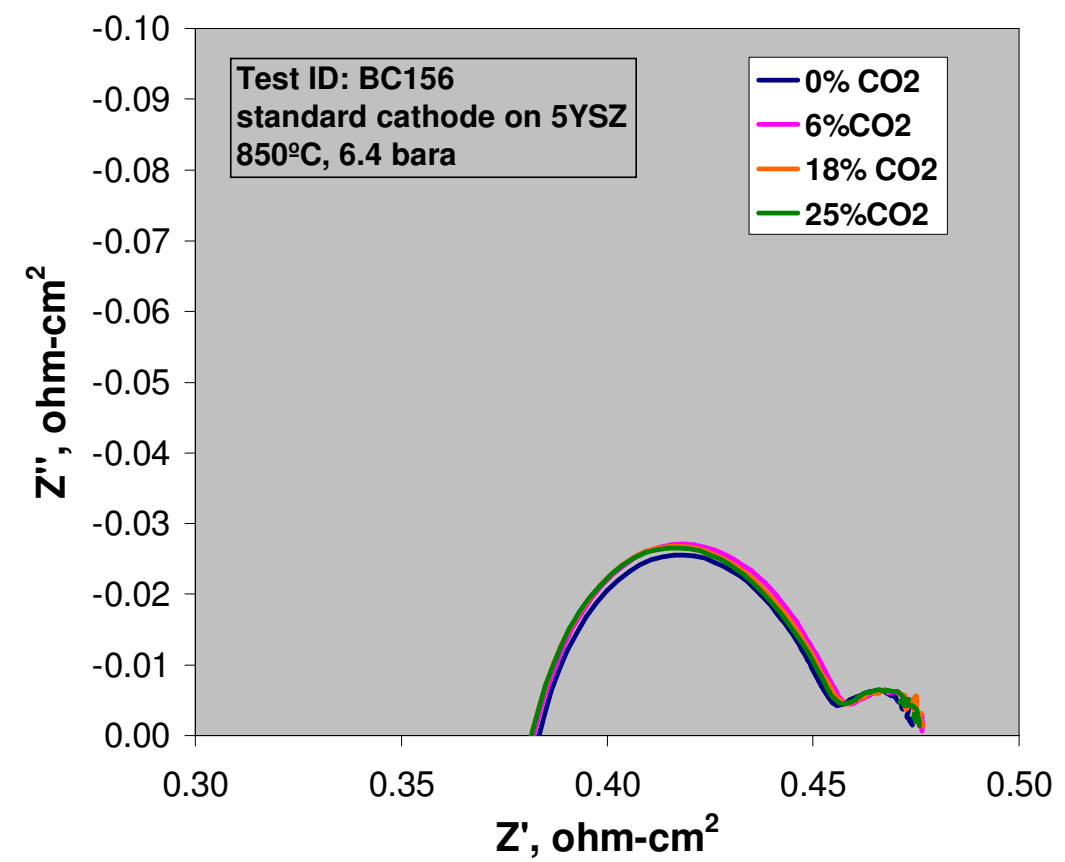

Figure 4.13 Effect of $\mathrm{CO}_{2}$ on Cathode $\mathrm{Rp}, 850^{\circ} \mathrm{C}, 6.4$ Bara, Constant $\mathrm{P}_{\mathrm{O} 2}$ 


\section{Effect of Steam Concentration}

The effect of steam on cathode performance was of importance because the original RRFCS system design used a direct combustion of the unused anode fuel to pre-heat the incoming cathode air. This was found to cause an unacceptable loss of performance and the system configuration has since been modified to eliminate this feature. The effect of steam on cathode performance, was found to be a long-term effect, but did not manifest itself in short-term (hour long) tests. Figure 4.14 below shows little change in polarization at steam levels from $3 \%$ to $26 \%$. Figure 4.15 shows the polarization at 1 and 6.4 Bara for the same $\mathrm{P}_{\mathrm{H} 2 \mathrm{O}}$ and dry conditions, which again shows the steam addition has little impact on short-term performance.

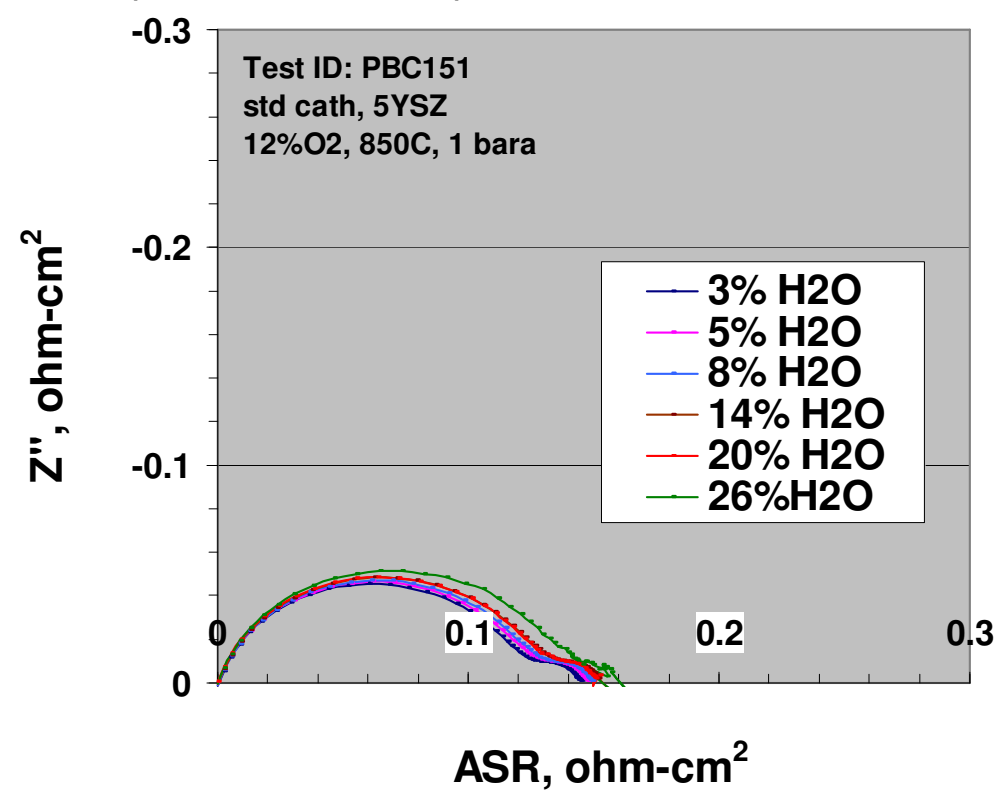

Figure 4.14 Effect of Steam on Cathode Performance for Short Term Test

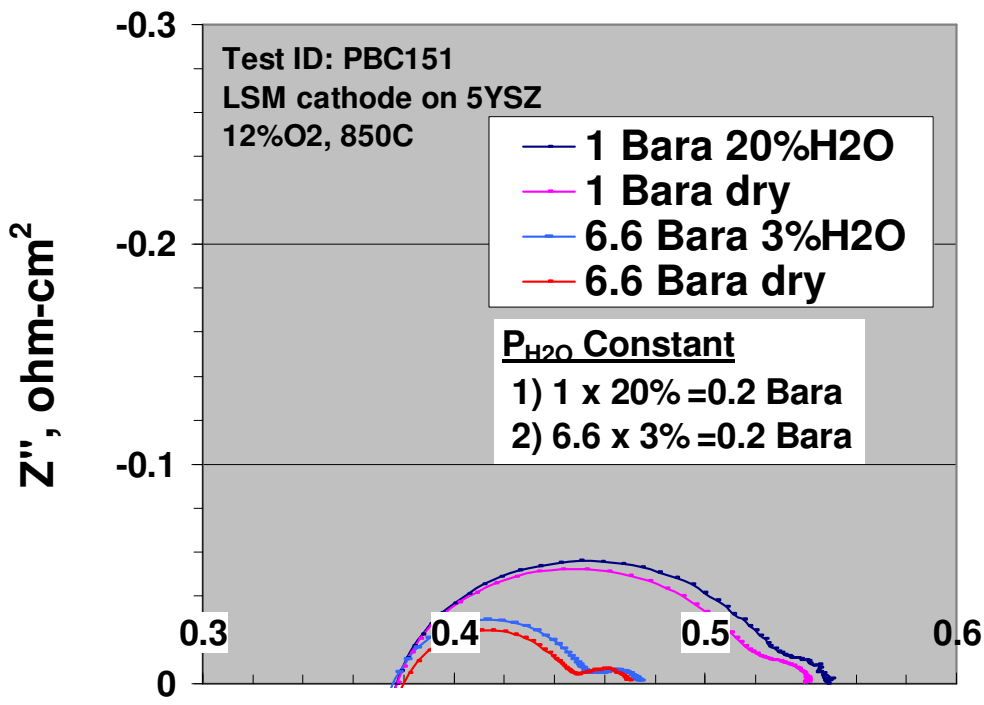

ASR, ohm-cm²

Figure 4.15 Effect of $\mathbf{P}_{\mathrm{H} 2 \mathrm{O}}$ on Cathode Performance for Short Term Test 


\section{Degradation of Cathode Symmetric Cells}

Longer-term testing was performed to begin investigating degradation trends with respect to pressure. Figure 4.16 below shows the traces of 4 tests conducted comparing pressure and cathode humidification (wet $=3 \%$ steam). The trends seem to show a small effect of the wet versus dry condition, but the effect of pressure is hard to discern. In general the degradation rate of these samples appears large.

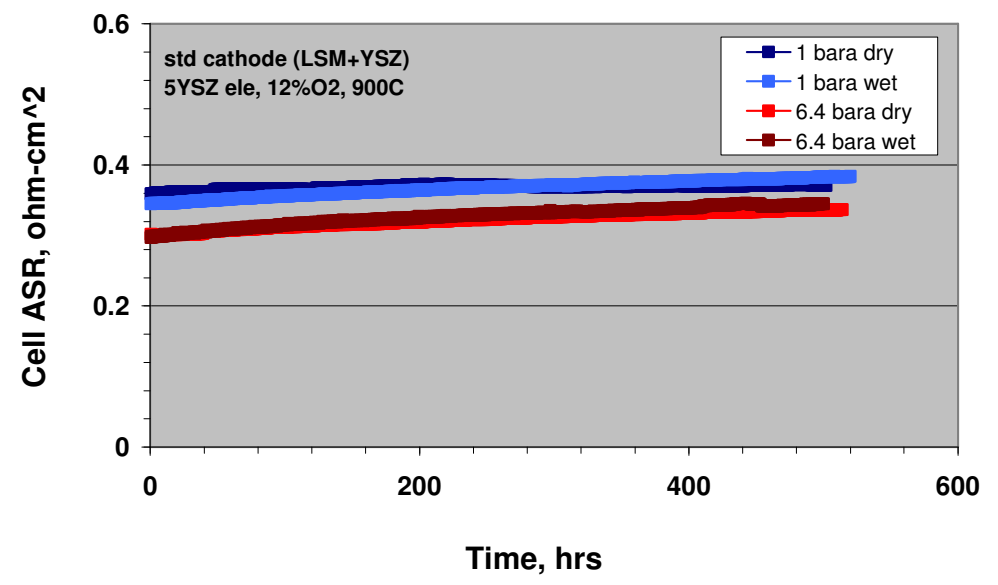

\section{Figure 4.16 Comparison of Degradation Traces under Constant Current Load}

Figures 4.17 and 4.18 show the impedance traces at 0 and 500 hours for the dry cathode cases at 1 and 6.4 Bara. When the performance change is deconvolved we determine that most of this loss is due to ohmic change, likely indicating degradation of the current collection rather than the cathode polarization. The polarization loss decreases for the dry 1 Bara case and is very small for the dry 6.4 Bara case. The polarization loss increase is larger for both cases with humidified cathode air, again being slightly larger than for the case at pressure.
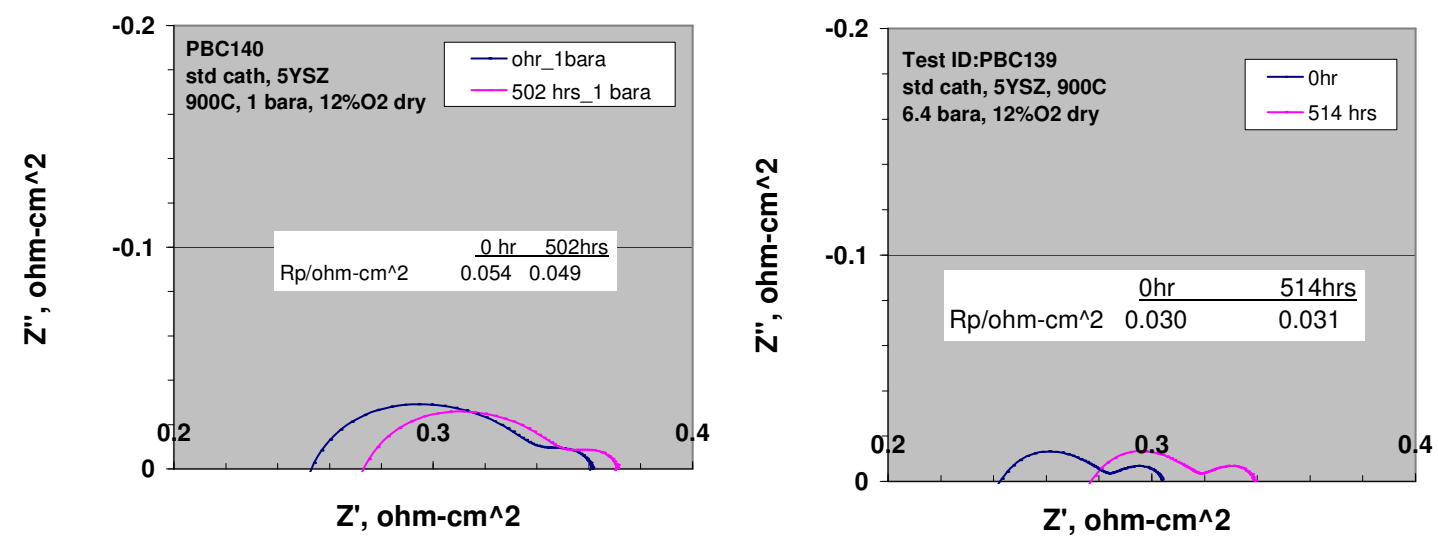

Figure 4.17 Impedance Traces at 0 and 500 hours at 900C, Dry Cathode, and a) 1 Bara, b) 6.4 Bara 

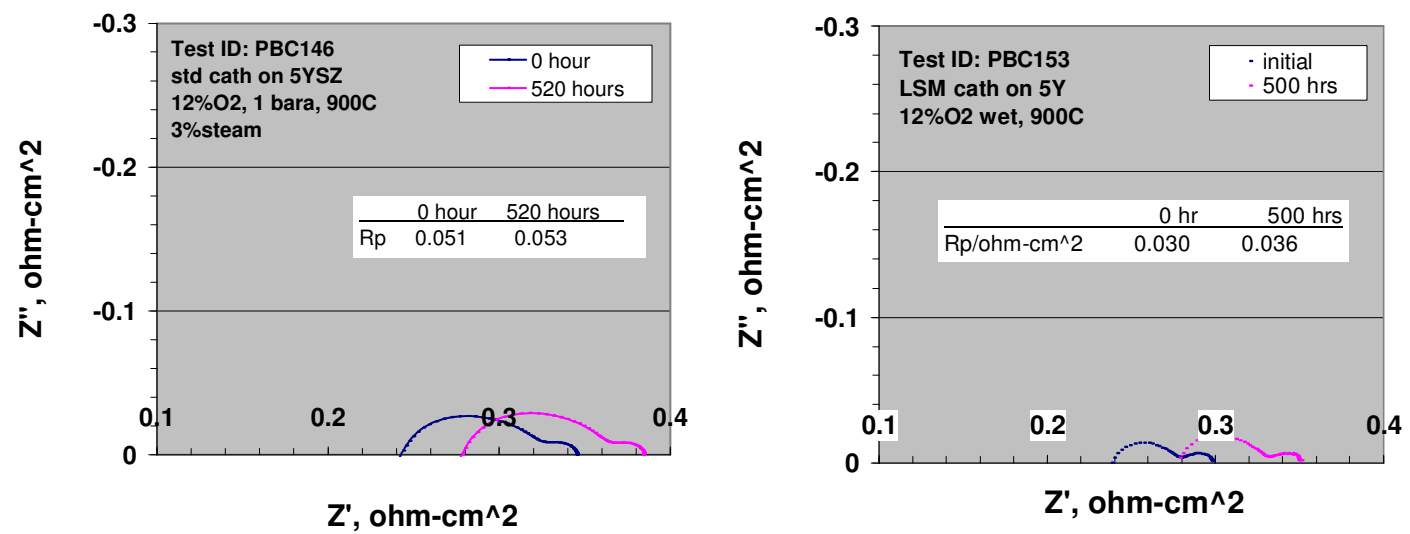

Figure 4. 18 Impedance Traces at 0 and 500 hours at $900 \mathrm{C}$, Wet Cathode, and a) 1 Bara, b) 6.4 Bara

\section{Summary of Button Cell Testing}

Improvement in cathode electrode performance is on the order of $33-40 \%$ at pressures of 6.4 Bara compared to atmospheric pressure. Key cathode operational parameters are the concentration and partial pressure of $\mathrm{O}_{2}$, and temperature. $\mathrm{CO}_{2}$ showed negligible impact on short term electrode performance. Steam at levels below $20 \%$ also showed negligible impact on short term electrode performance, but has been found to cause a longer-term loss of performance, especially at lower temperatures.

The effect of partial pressure of $\mathrm{O}_{2}\left(\mathrm{P}_{\mathrm{O}}\right)$ decreases the activation polarization, although there appears to be a secondary effect of absolute pressure as well. The concentration of $\mathrm{O}_{2}$ impacts the diffusion component of the polarization, which is largely insensitive to absolute pressure.

The effect of pressure on long term performance was not established. In general, due to the non-prototypic nature of the current collecting for the button cell samples compared to the full cells, and their apparent instability during long-term testing, the degradation tests were not considered to be as valuable as hoped for deconvolution of degradation results. 


\subsection{Triple Cell Testing}

The testing of full fuel cells was performed in both atmospheric and pressurized test rigs. The effect of pressure, temperature, fuel composition, and cathode composition were examined. Longer term degradation effects were also examined considering the effects of pressure and cathode steam composition. Testing was performed on three-cell samples (triple-cells) which were fully instrumented to give a breakdown of cell and interconnect components under atmospheric and elevated pressures as described in Section 3.0.

\section{Effect of Pressure}

Figure 5.1 shows the effect of pressure for a test at $900^{\circ} \mathrm{C}$ which shows the total electrode polarization is reduced by about $0.09 \mathrm{ohm}-\mathrm{cm}^{2}$ going from 1 to 6.5 Bara. Of note is that about $70 \%$ of the improvement takes place between 1 and 4 Bara.

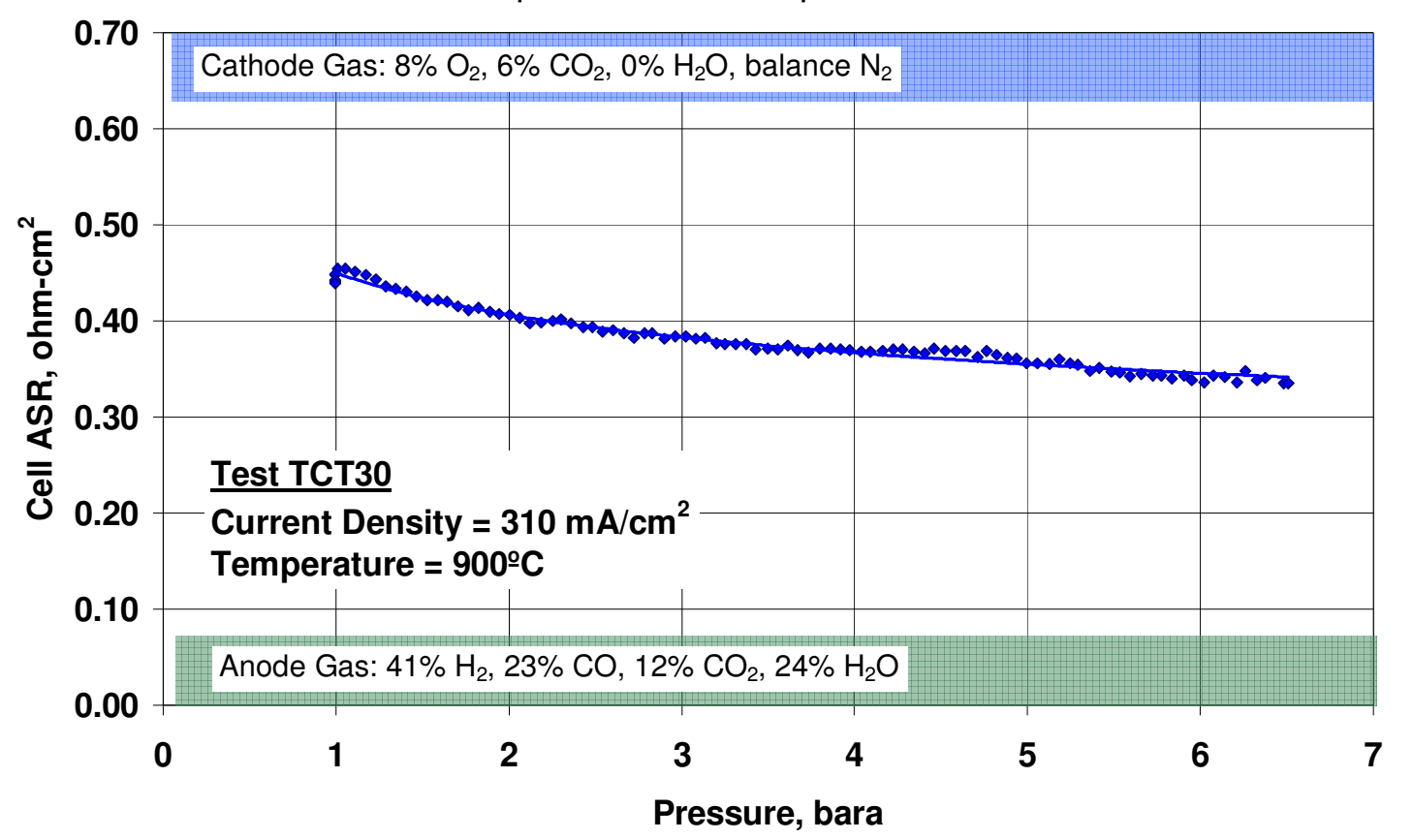

Figure 5.1 Cell ASR reduction as a function of pressure at $900^{\circ} \mathrm{C}$

The VI curves at 1 and 6.5 Bara are shown in Figure 5.2 which again shows the total electrode polarization is reduced by about $0.09 \mathrm{ohm}-\mathrm{cm}^{2}$ going from 1 to 6.5 Bara. This is more than double the reduction observed for the cathode polarization alone. The impedance trace of another test is shown in Figure 5.3 which shows that the improvement in ASR is in the polarization term. As noted in Section 2.0 and as will be discussed in Section 6.0, it is expected that pressure impacts not only the anode activation but also the concentration polarization because of the small pore size and thickness of the substrate in which Knudsen diffusion will be a factor. This improvement results in a decrease in total ASR of over $20 \%$, which when coupled with increased Nernst potential yields a much higher power density. For example, at an operating voltage of 0.8 volts, the power density at 6.5 Bara is double that at 1 Bara. 


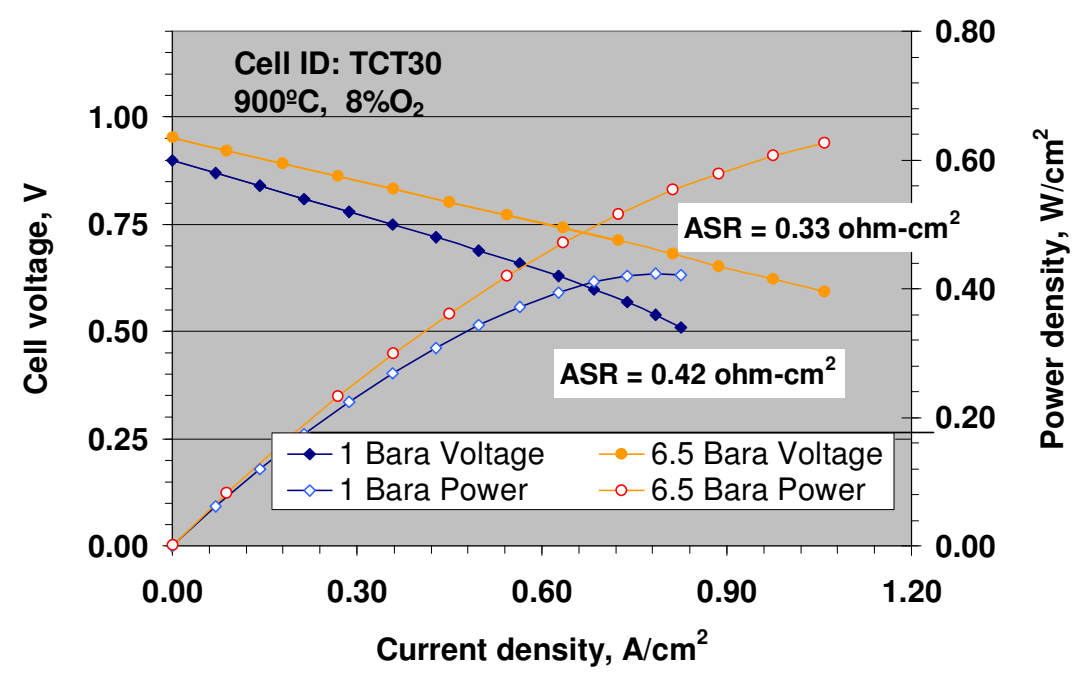

Figure 5.2 Effect of Pressure on Performance of a Triple-Cell Sample at $900^{\circ} \mathrm{C}$

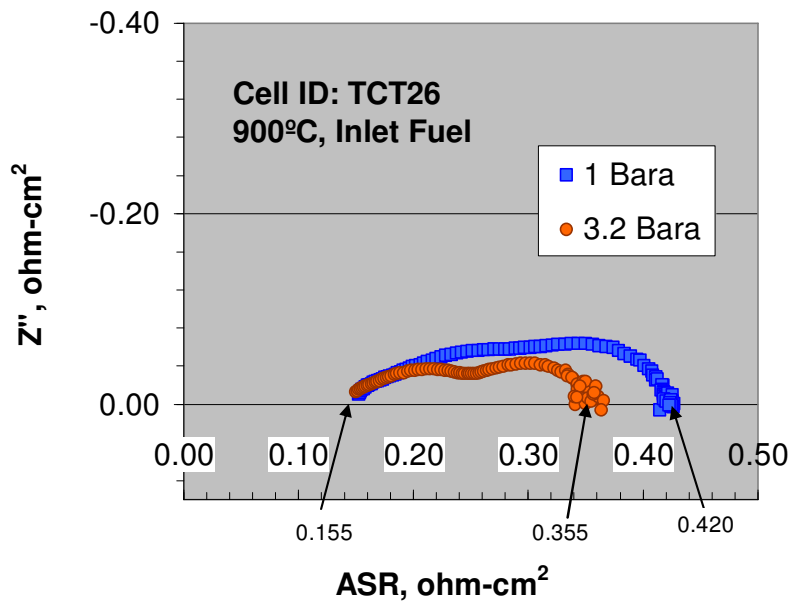

Figure 5.3 Impedance Trace of TCT26 at $900^{\circ} \mathrm{C}, 1$ and 3.2 Bara

\section{Effect of Fuel Composition}

Figures 5.4 and 5.5 show the effect of fuel composition on performance. The fuel compositions tested are shown in Table 5.1. First, the effect of pressure is again shown to improve the total ASR by about 0.09 to $0.10 \mathrm{ohm}-\mathrm{cm}^{2}$. Second, the effect of the change in fuel composition is on the order of 0.09 to $0.10 \mathrm{ohm}-\mathrm{cm}^{2}$. It is discussed in Section 6.0 that the degree to which fuel composition affects performance is highly dependent upon the permeability of the substrates.

Table 5.1 - Fuel Composition at Bundle Inlet and Bundle Outlet

\begin{tabular}{|c|c|c|}
\hline Constituent & Bundle Inlet & Bundle Outlet \\
\hline $\mathrm{H}_{2}$ & $41 \%$ & $21 \%$ \\
\hline $\mathrm{CO}$ & $23 \%$ & $14 \%$ \\
\hline $\mathrm{CO}_{2}$ & $12 \%$ & $22 \%$ \\
\hline $\mathrm{H}_{2} \mathrm{O}$ & $24 \%$ & $43 \%$ \\
\hline
\end{tabular}




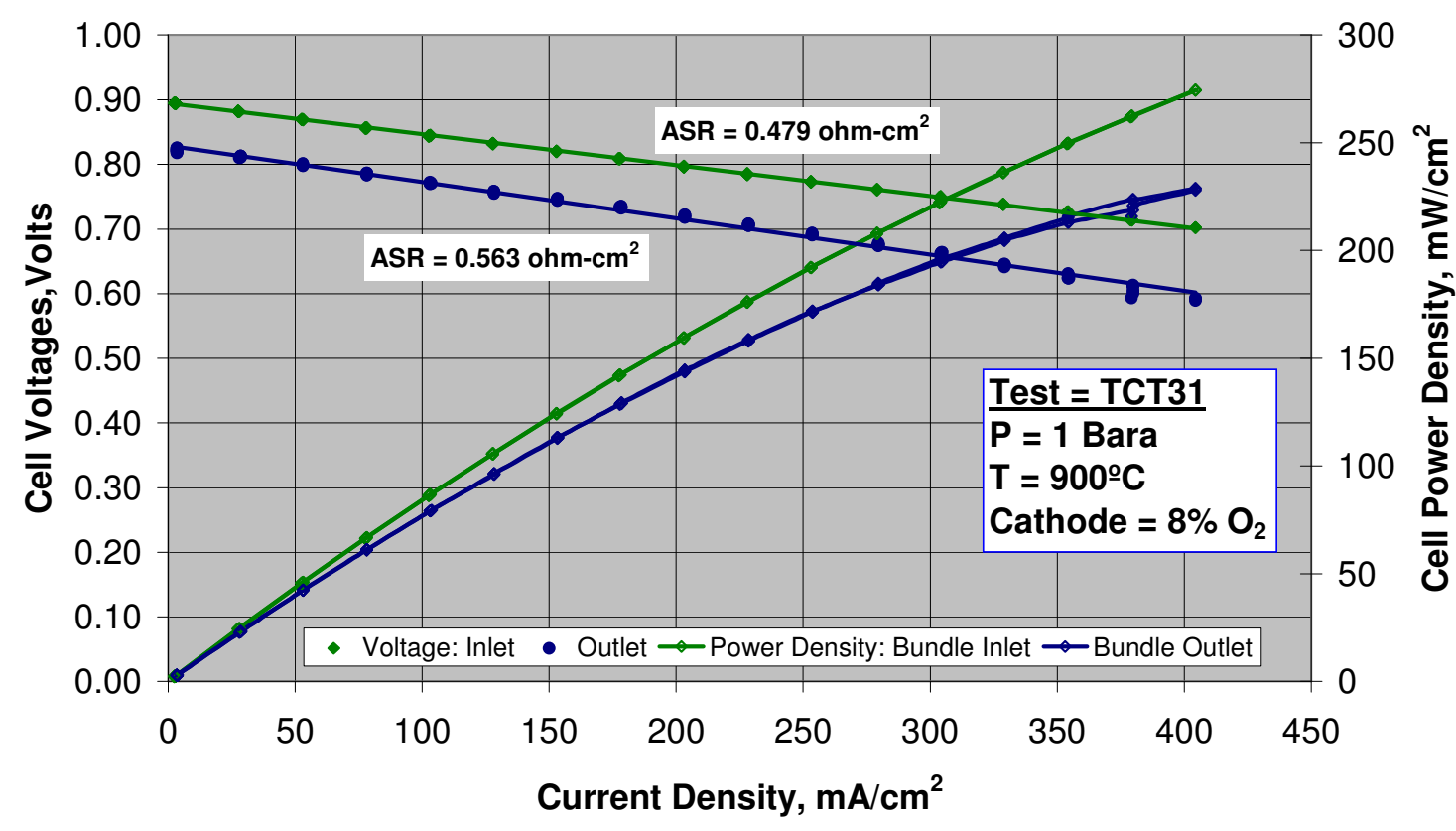

Figure 5.4 Effect of Fuel Composition at $900^{\circ} \mathrm{C}, 1$ Bara

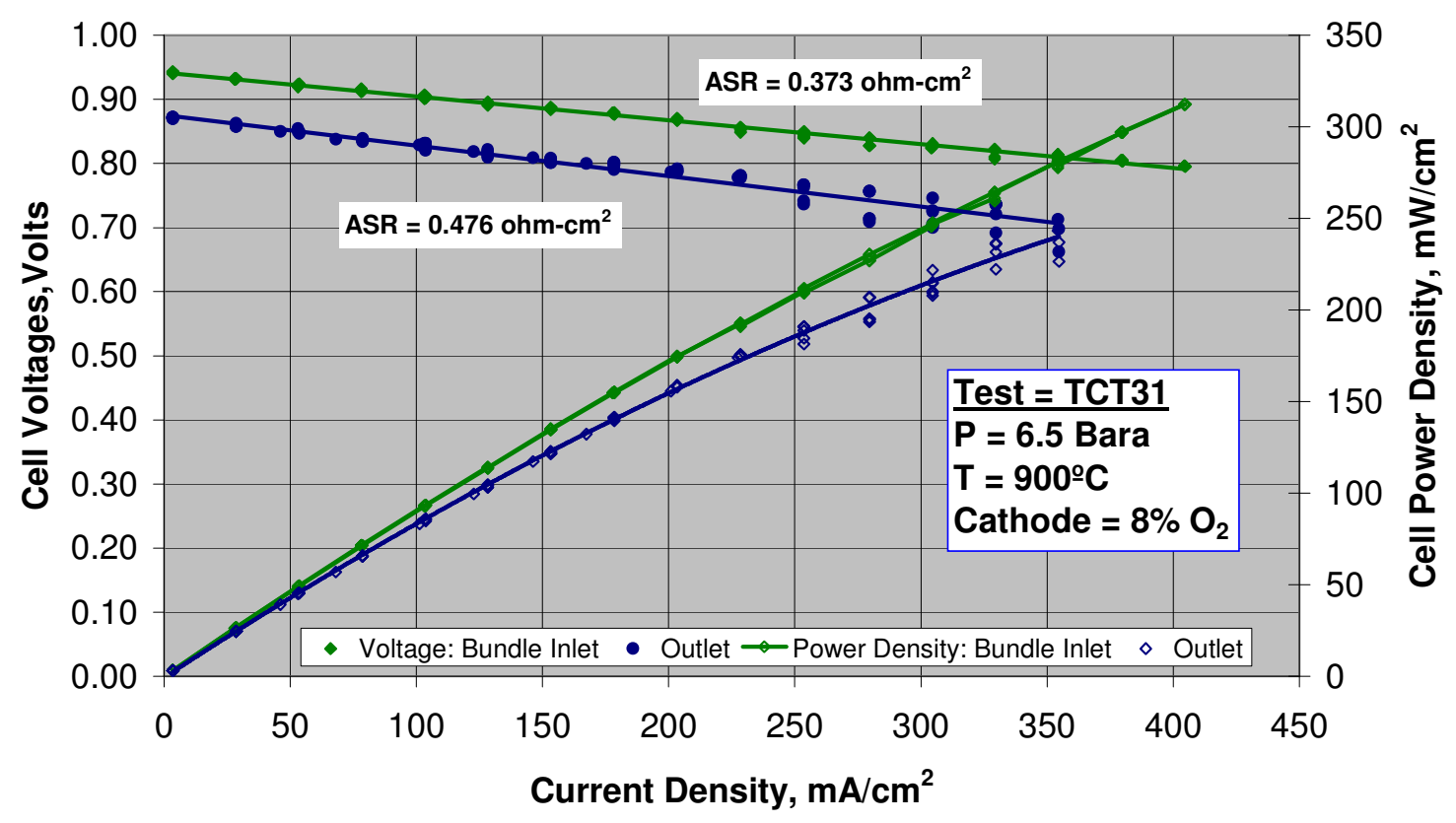

Figure 5.5 Effect of Fuel Composition at $900^{\circ} \mathrm{C}, 6.5$ Bara 


\section{Effect of $\mathrm{O}_{2}$ Concentration}

Prior to performing this test, the sensitivity to total cathode flow was checked at an $\mathrm{O}_{2}$ concentration of $8 \%$. At flows above 20 slpm the ASR was not sensitive to flow, and a total flow of about $24 \mathrm{slpm}$ was used for this test. Figure 5.6 shows the effect of oxygen concentration on performance. The effect is slightly larger than observed on the button cell testing described in Section 4.0. Note that at concentrations lower than $4 \%$ the ASR begins to increase rapidly.

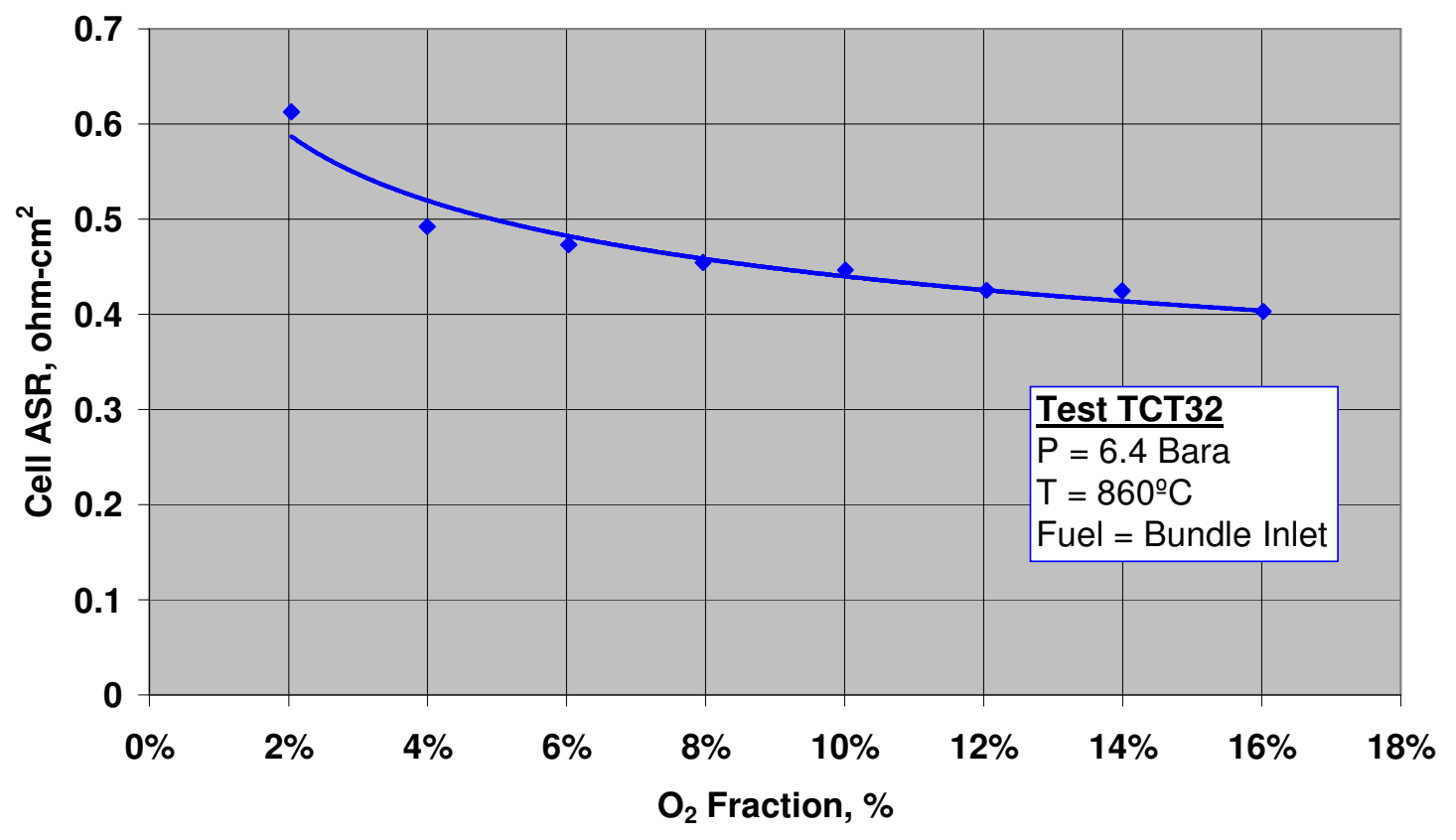

Figure 5.6 Effect of Oxygen Concentration on Cell ASR at 6.4 Bara and $860^{\circ} \mathrm{C}$

\section{Effect of Steam Concentration}

The original RRFCS system design used a direct combustion of the unused anode fuel to pre-heat the incoming cathode air. This was found to cause an unacceptable loss of performance and the system configuration has since been modified to eliminate this feature. Figure 5.7 shows the short term effect of $13 \%$ cathode steam on performance. The traces show that there was no significant effect of steam on short-term performance, confirming what was observed in button cell testing. 

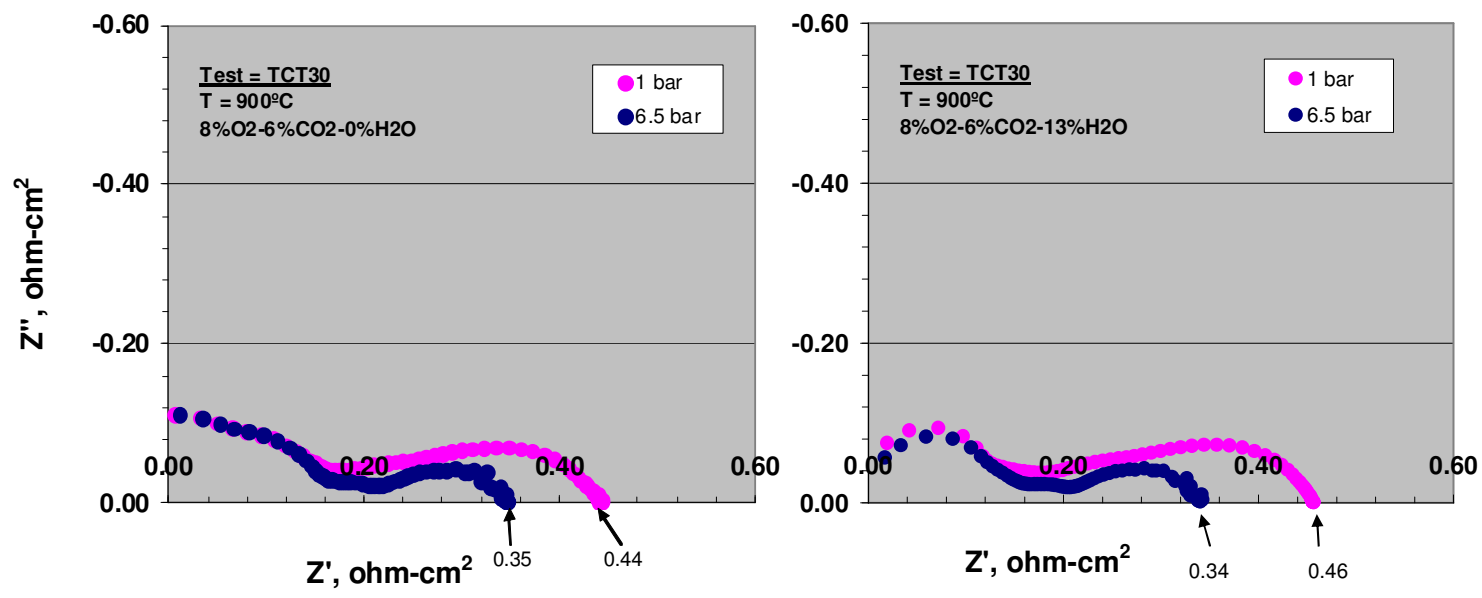

Figure 5.7 Short-term Effect of $13 \%$ Steam on Performance at 1 and 6.5 Bara

Figure 5.8 shows a time trace of a triple-cell test (TCT40) which was started up with steam on the cathode. At 40 hours, the steam was removed from the cathode stream, resulting in an immediate improvement in performance followed by a continued gradual improvement. Impedance measurements were taken at about 38 and 59 hours. Figure 5.9 shows the two impedance curves, which show that the effect is a cathode polarization effect. Frequency analysis of impedance data showed that the increased polarization caused by steam is a slower process on the order of $10 \mathrm{~Hz}$. This is similar to a mass transport process, and suggests a surface exchange phenomenon in the cathode.

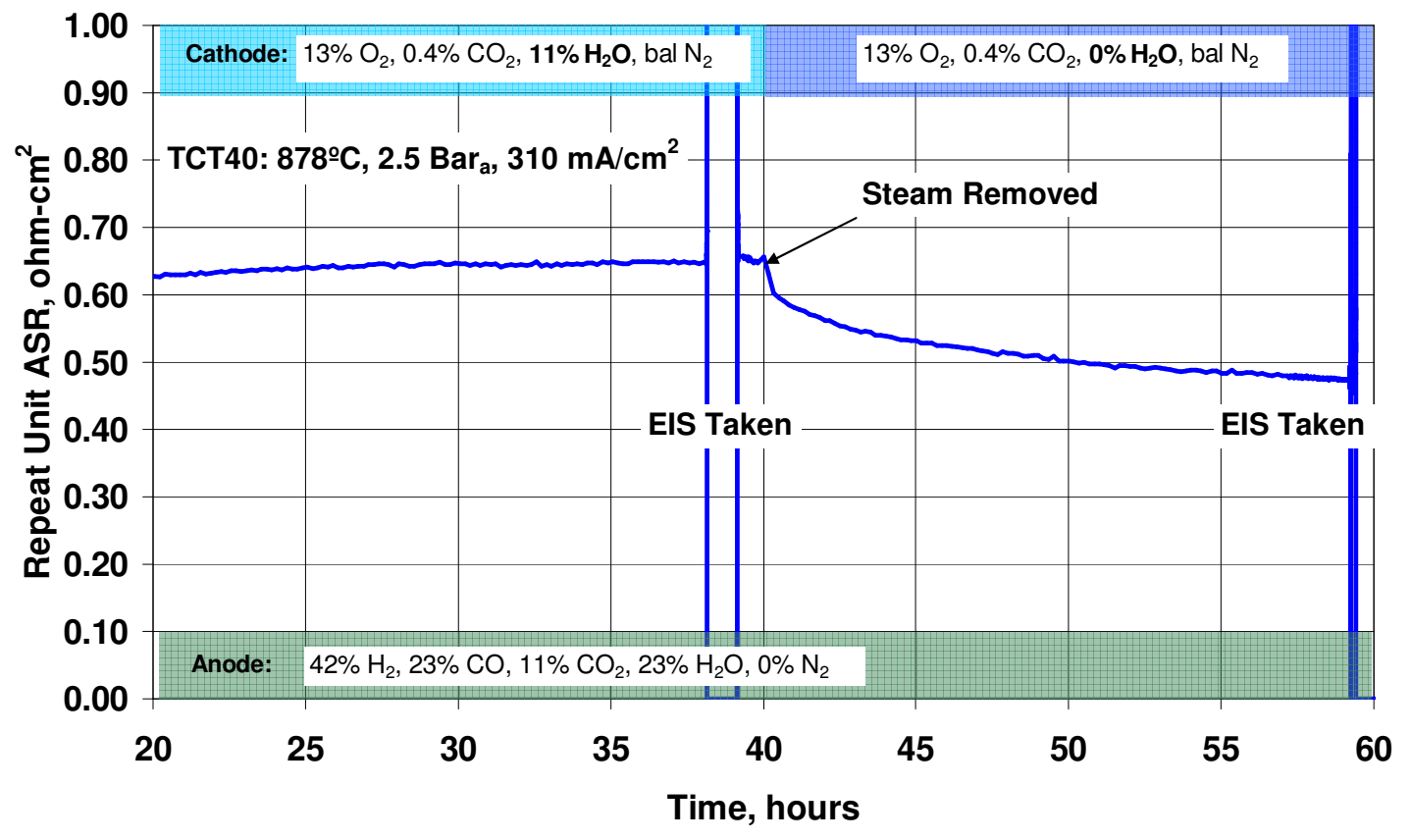

Figure 5.8 Time Trace Showing Reduced ASR after Cathode Steam is Removed 


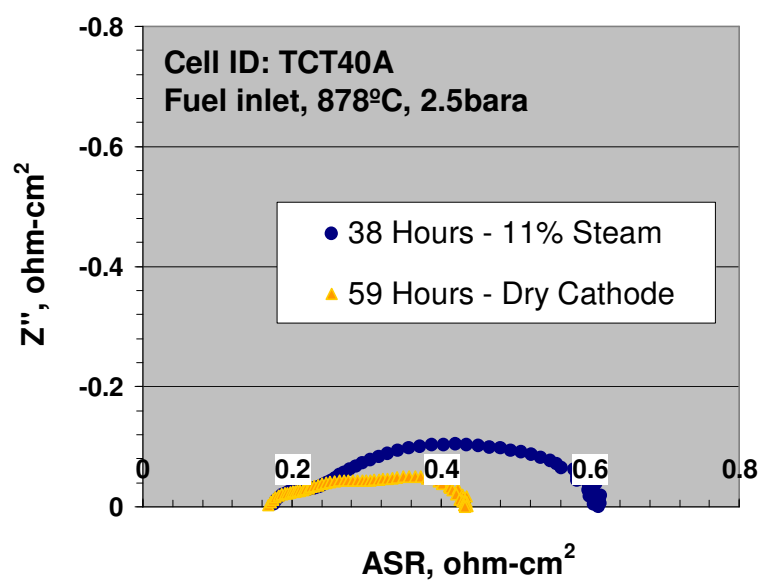

Figure 5.9 Impedance Trace for TCT40A at 38 and 59 Hours

\section{Effect of Temperature and Burn-In (plus steam)}

The effect of temperature on the cells is shown in Figure 5.10 along with the effect of steam. An important finding was that the effect of steam was highly temperature dependent. The loss of performance at temperatures below $850^{\circ} \mathrm{C}$ was very large for the standard LSM + YSZ cathodes. Figure 5.10 is for a case early in the operation of the cells (less than 200 hours) before the cell "burn-in" takes place. This phenomenon is believed to occur due to the mix of materials used on the anode and anode current collector layers for the cell technology used at this time. After burn-in is completed, the cell ASR tends to be lower than at first, and is relatively stable for the remainder of the test. Figure 5.11 shows ASR data as a function of temperature with and without steam on the cathode after burn-in has occurred.

\section{Degradation Testing}

Degradation testing was conducted on several tests, however many were affected by rig related issues which cut tests short. Three test which ran 1000 hours without incident are shown in Figures 5.12 and 5.13. In these tests, triple-cell samples which were subjected to atmospheric and pressurized conditions, with high and low cathode steam concentration. Figure 5.12 shows the "burn-in" behavior described above, and shows that the atmospheric test with steam has a higher ASR from the start. Figure 5.13 shows that the effect of steam is a major factor in the degradation rate. The test at 6 Bara showed marginally higher degradation than at 1 Bara, but data was insufficient to substantiate the effect of pressure on degradation. 


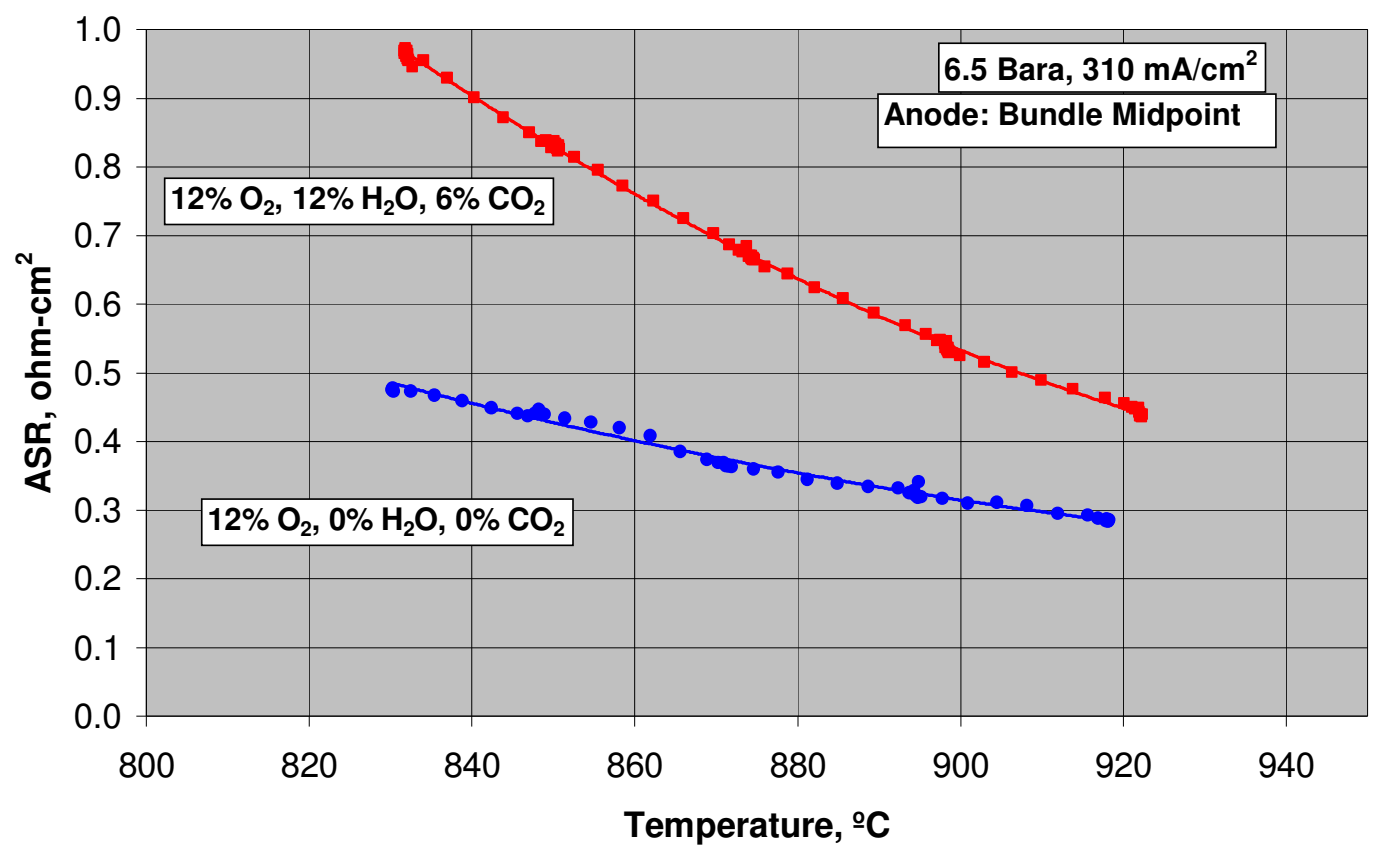

Figure 5.10 Effect of Steam and Temperature for Pre-Burn-in Case

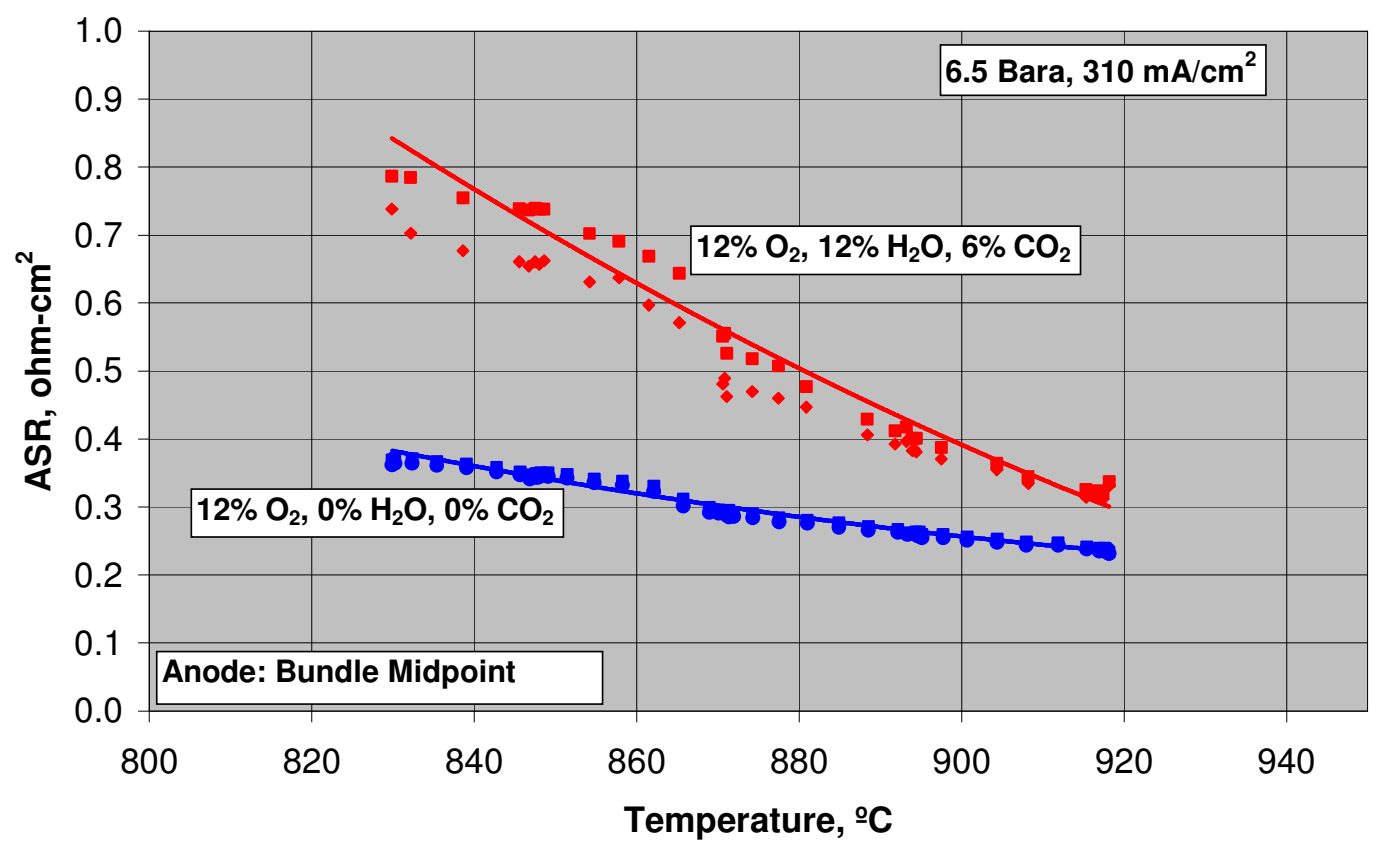

Figure 5.11 Effect of Steam and Temperature for Post-Burn-in Case 


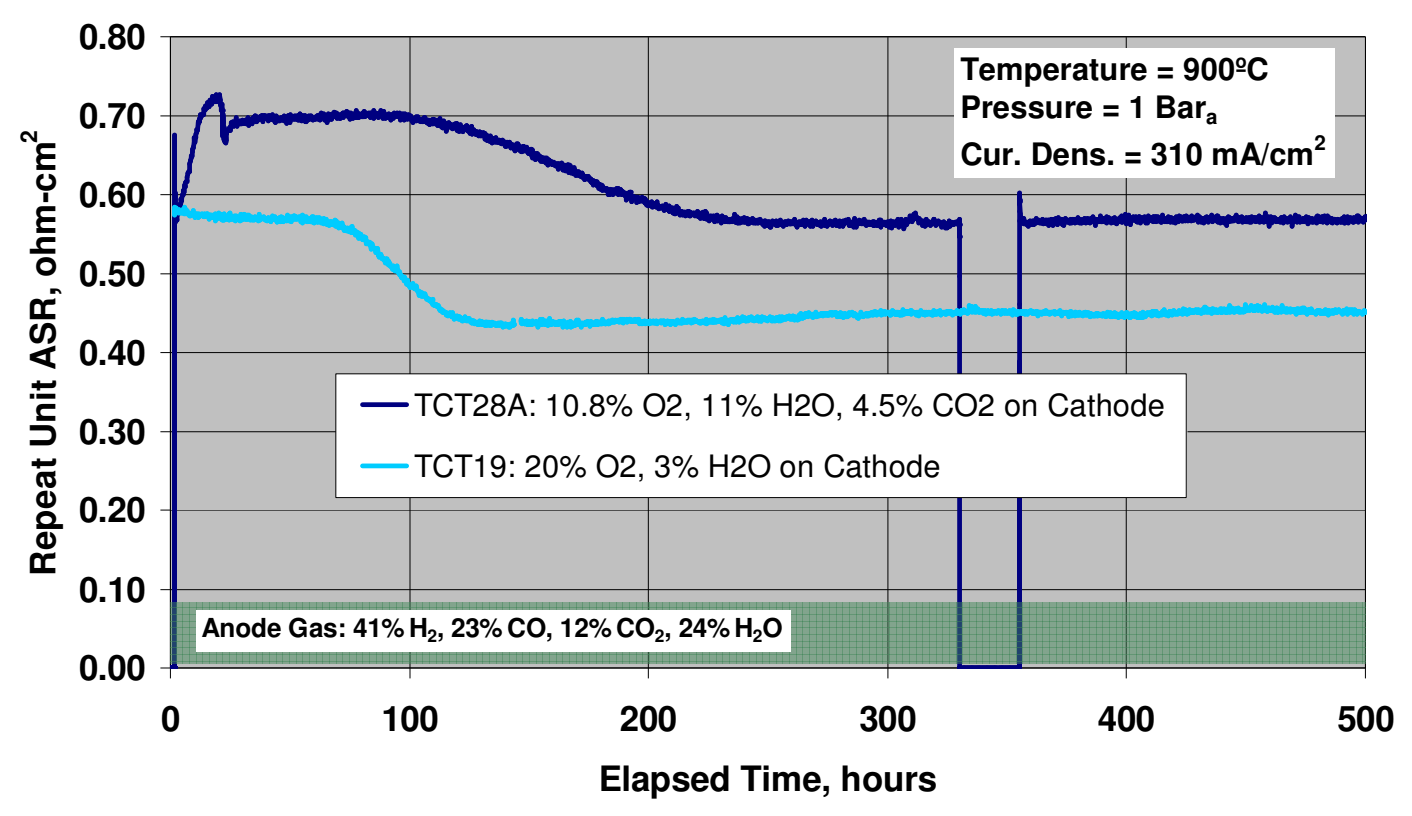

Figure 5.12 Time Trace for 0 - 500 Hours on Triple-Cell Samples

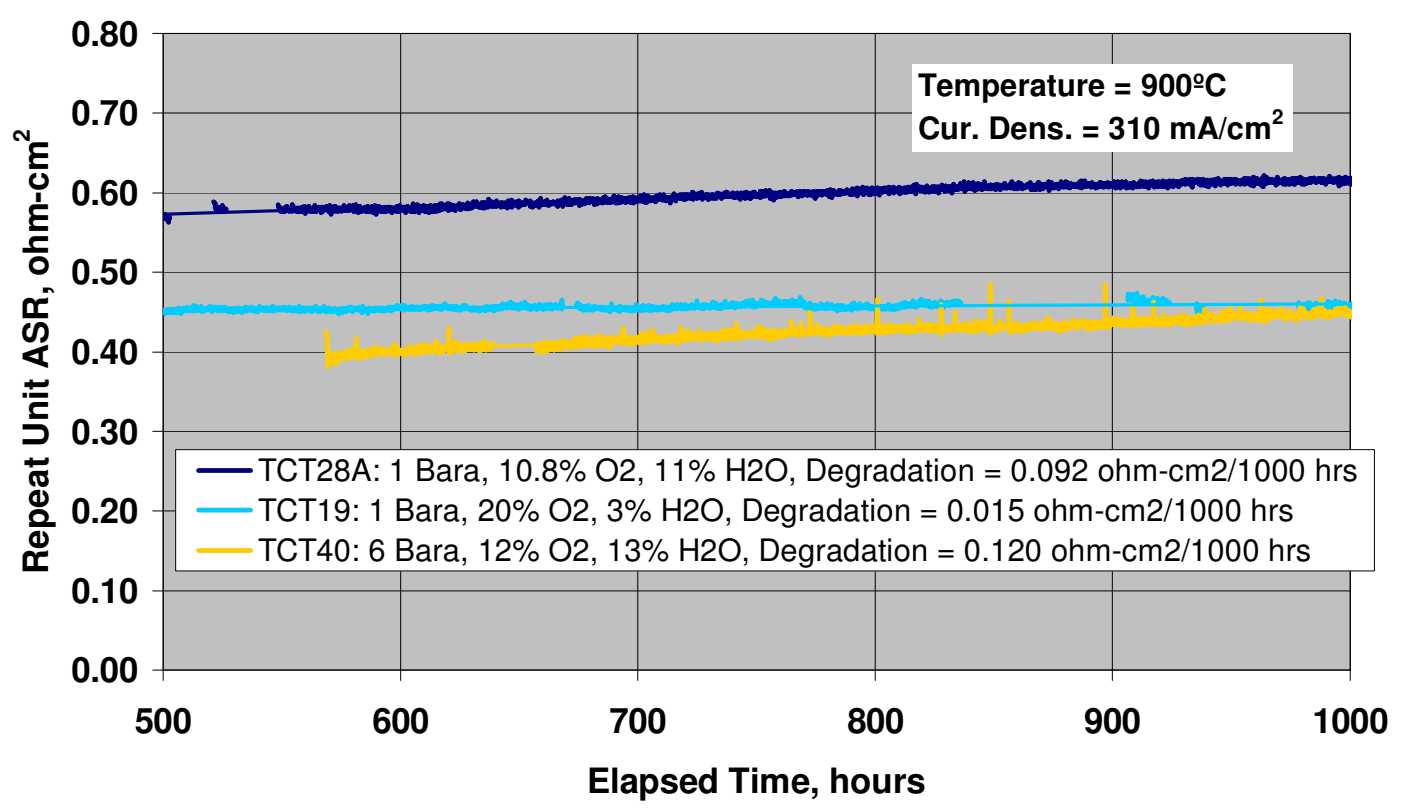

Figure 5.13 Time Trace for 500 - 1000 Hours on Triple-Cell Samples 


\section{Summary of Triple-Cell Testing}

The effect of pressure was found to reduce the polarization resistance of the full fuel-cell beyond the reduction determined for the cathode alone. The total reduction in ASR was on the order of $0.10 \mathrm{ohm}-\mathrm{cm}^{2}$ for a pressure increase from 1 to $6.5 \mathrm{Bara}$, with about $70 \%$ of the improvement being realized from 1 to 4 Bara.

The effect of the change in fuel composition is on the order of 0.09 to $0.10 \mathrm{ohm}-\mathrm{cm}^{2}$, although the degree to which fuel composition affects performance is highly dependent upon the permeability of the substrates.

An important finding was that the effect of steam was highly temperature dependent. The loss of performance at temperatures below $850^{\circ} \mathrm{C}$ was very large for the standard LSM + YSZ cathodes.

Steam is also a major factor in the degradation rate. Data at pressure was insufficient to substantiate the effect of pressure on degradation. 


\subsection{Modeling}

A basic electrochemical model was put together based partly on data generated in this program. The model is similar to one reported elsewhere ${ }^{6}$ and takes the basic form of:

Vcell $=E_{\text {Nernst }}-\eta_{\text {ohmic }}-\eta_{\text {conc,anode }}-\eta_{\text {conc,cathode }}-\eta_{\text {act,cathode }}-\eta_{\text {act,anode }}$

Where:

$\mathrm{E}_{\text {Nernst }}=$ nernst potential based on the bulk anode and cathode compositions

$\eta_{\text {ohmic }}=$ the resistance of anode and cathode current collector layers and electrolyte

$\eta_{\text {conc }}=$ concentration polarization for either anode or cathode

$\eta_{\text {act }}=$ activation polarization for either anode or cathode

The approach to building this model was sequenced as follows:

- Nernst potential calculated from gas compositions

- Current collector layer ohmic losses based upon separately measured conductivities and analytical solution

- Electrolyte ohmic loss based upon theoretical material conductivity adjusted by measured cell ohmic loss data from EIS

- Cathode concentration polarization is calculated, and is small

- Anode concentration polarization is calculated based on a multi-component diffusion model

- Cathode polarization is based upon measured cathode symmetric button cell data

- Anode polarization is adjusted last to make overall loss match data measured from full cell test data

This process is described for each of these components below.

\section{Nernst Potential}

The nernst potential across the cell is calculated from the bulk anode and cathode compositions:

$$
E=\frac{\left(R_{J}\right)\left(T_{c}\right) \ln \left(\frac{P O 2 c b}{P O 2 a b}\right)}{(4)(F)}
$$

Where:

$\mathrm{E}=$ reversible voltage calculated with bulk gas properties $(\mathrm{V})$

$$
\mathrm{R}_{\mathrm{J}}=\text { Gas constant }=8.3145 \frac{\mathrm{J}}{\text { gmoleK }}
$$

\footnotetext{
${ }^{6}$ Electrochemical model of the integrated planar solid oxide fuel cell (IP-SOFC), Paola Costamagna, Azra Selimovic, Marco Del Borghi, Gerry Agnew, Chemical Engineering Journal 102 (2004) 61-69, 22

February 2004
} 
$\mathrm{T}_{\mathrm{C}}=$ temperature $\left({ }^{\circ} \mathrm{C}\right)$

$\mathrm{PO}_{\mathrm{ib}}=$ oxygen partial pressure $(\mathrm{atm})(\mathrm{i}=$ anode, cathode) in bulk gases

$\mathrm{F}=$ Faraday constant $=96485$ Coulombs $/$ mole

\section{Electronic Resistances}

The anode and cathode current collector layer resistances are based upon the layer conductances of each layer and the current density. This is also show in the reference ${ }^{6}$. Layer conductances are based upon separate effect tests for the anode and cathode layers.

The electrolyte resistance is based upon the fundamental conductivity for the zirconia based material and is modified based upon EIS data taken, such as shown in Figure 6.1. The left intercept represents the ohmic portion of the cell loss. So by calculating the anode and cathode current collector loses based on layer conductances the remaining portion is attributed to the electrolyte.

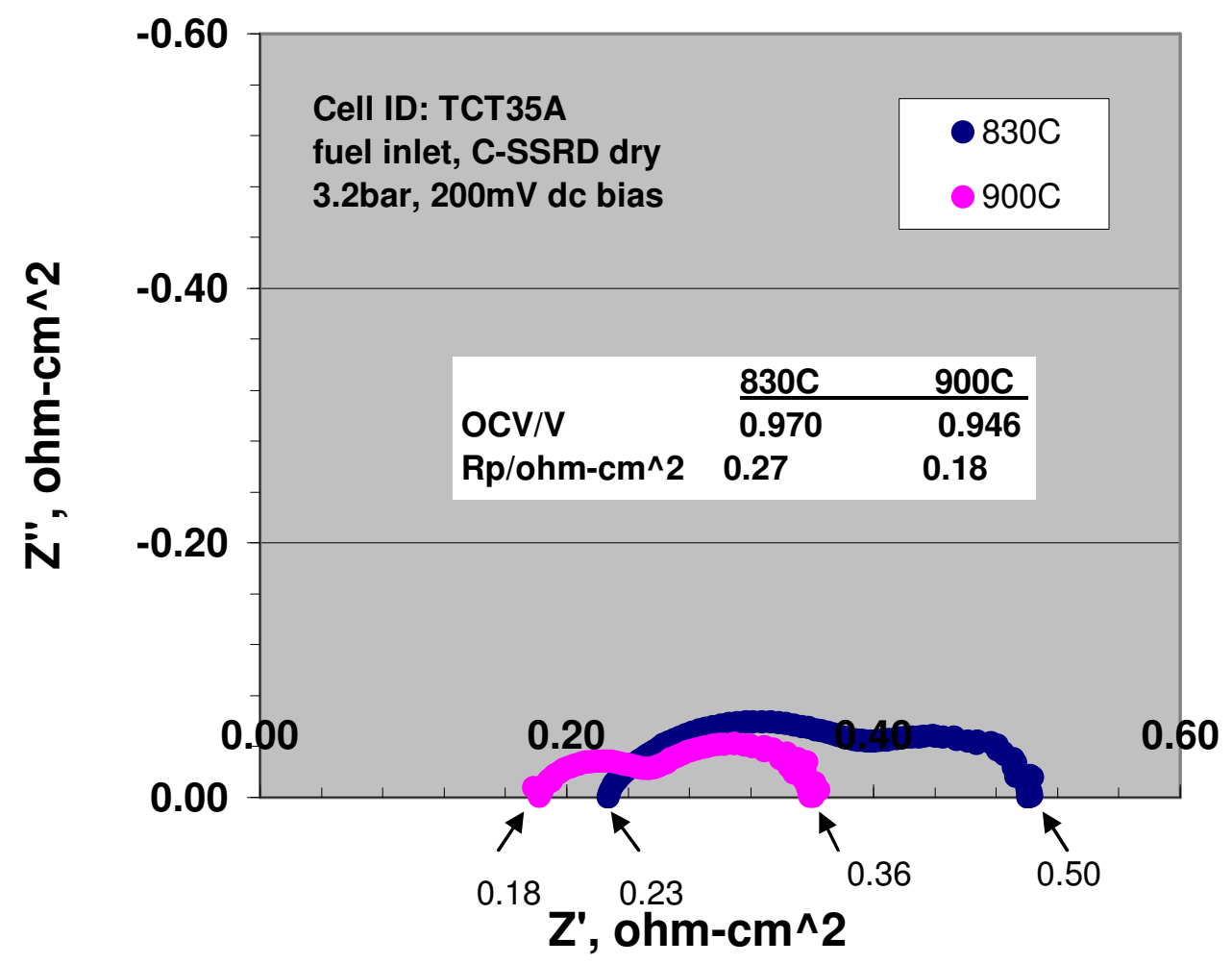

Figure 6.1 - Example Showing Impedance Data from Fuel Cell Test

\section{Concentration Polarization}

As the cell arrangement is anode supported, the cathode diffusion length is relatively small on the actual cells. However, the button cell data presented in Section 4.0 showed a clear diffusion loss which was accounted for in the modeling effort. In the model developed on this program, a standard two component diffusion resistance calculation is 
performed to predict the equivalent voltage loss due to the $\mathrm{P}_{\mathrm{O} 2}$ gradient through the porous cathode current collector and cathode layers.

On the anode side, there is a thick substrate as shown in Figure 6.2 through which fuel must flow into the active anode while the reaction products, $\mathrm{H}_{2} \mathrm{O}$ and $\mathrm{CO}_{2}$, must flow back out into the bulk fuel stream. In the model developed on this program, an interpolation of component interactions was used to model the anode flows. Once the concentration of $\mathrm{H}_{2}$ and $\mathrm{H}_{2} \mathrm{O}$ at the anode are established, the concentration overpotential can be determined.

$$
\eta_{\mathrm{conc}, \mathrm{a}}=\frac{\left(R_{J}\right)\left(T_{K}\right) \ln \left(P_{O 2 a} / P_{O 2 a b}\right)}{(4)(F)}
$$

Where:

$$
\begin{aligned}
& \mathrm{P}_{\mathrm{O} 2 \mathrm{ab}}=\text { partial pressure of oxygen in anode bulk, }=\left[\frac{\left(K_{P a}\right)\left(P_{H 2 O a b)}\right.}{\left(P_{H 2 a b}\right)}\right]^{2},(\text { atm }) \\
& \mathrm{P}_{02 \mathrm{a}}=\text { partial pressure of oxygen at active anode, }=\left[\frac{\left(K_{P a}\right)\left(P_{H 2 O a}\right)}{\left(P_{H 2 a}\right)}\right]^{2},(\text { atm }) \\
& \mathrm{K}_{\mathrm{Pa}}=\text { equilibrium constant for fuel }=\exp \left\{-\left[\frac{239500}{\left(R_{J}\right)\left(T_{K}\right)}-\frac{8.14 \ln \left(T_{K}\right)}{\left(R_{J}\right)}+\frac{9.25}{\left(R_{J}\right)}\right]\right\},\left(\mathrm{atm}^{1 / 2}\right)
\end{aligned}
$$

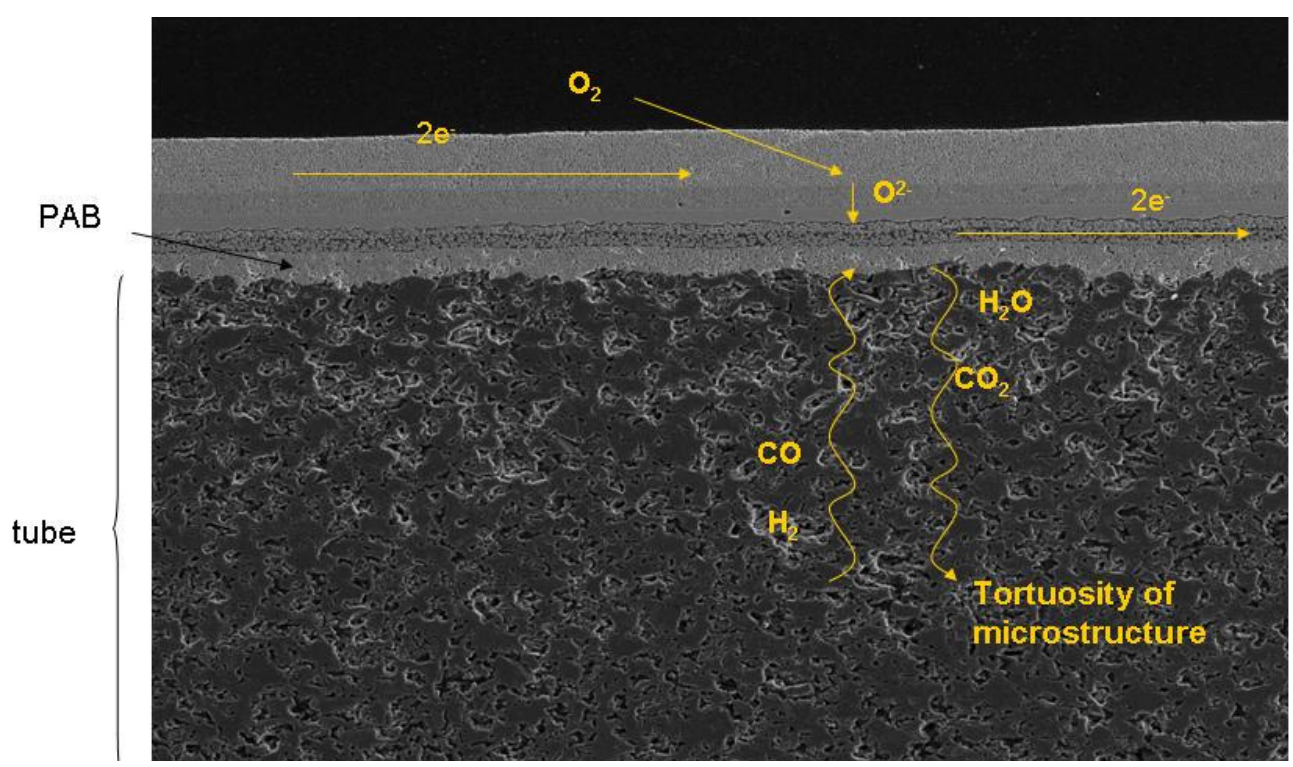

Figure 6.2 - Porous structure of fuel cell for gas diffusion 


\section{Activation Polarization}

Two terms remain to be defined, the anode and cathode activations. The cathode activation polarization was a primary area of study on this program as presented in Section 4. We start with the Butler-Volmer equation for cathode activation:

Where:

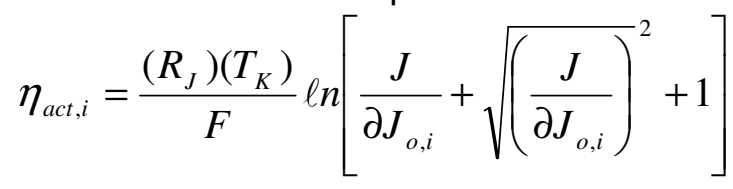

$\mathrm{J}=$ current density $\left(\mathrm{amps} / \mathrm{cm}^{2}\right)$

$\mathrm{J}_{\mathrm{o}, \mathrm{i}}=$ exchange current density $(\mathrm{i}=$ anode, cathode $)\left(\mathrm{amps} / \mathrm{cm}^{2}\right)$

The exchange current density on the cathode side is of the form:

$$
\mathrm{J}_{\mathrm{o}, \mathrm{c}}=\left(\mathrm{K}_{\mathrm{c}}\right)\left(\frac{P O_{2 c}}{P_{r e f}}\right)^{N} \exp \left[\frac{(\text { Eact }, c)}{\left(R_{J}\right)\left(T_{K}\right)}\right]
$$

Where:

$\mathrm{Kc}=$ pre-exponential constant

$\mathrm{N}=$ pressure effect exponent

Eact $=$ cathode activation energy

$\mathrm{P}_{\mathrm{O} 2 \mathrm{c}}=$ cathode partial pressure of oxygen, atm

Pref $=$ reference pressure, generally set at $1 \mathrm{~atm}$

\section{Fitting Cathode Data}

Now taking the data presented in section 4.0 we can see that the equation form presented above is inadequate to match all the data sets collected. Figure 6.3 shows data for cathode $\mathrm{Rp}$ as a function of $\mathrm{P}_{\mathrm{O} 2}$ at varying pressure and $\mathrm{O}_{2}$ concentrations.

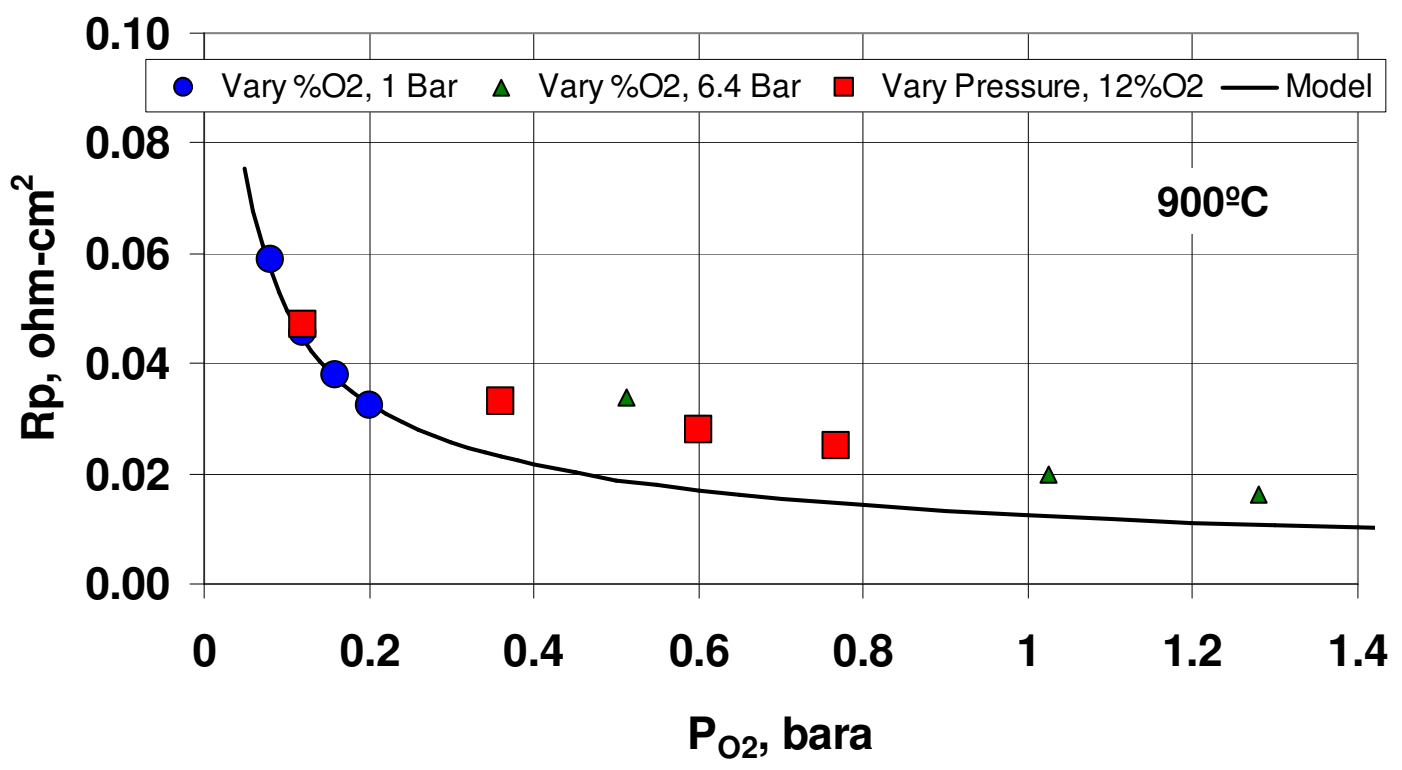

Figure 6.3 - Comparison of Cathode Rp Model to Data 
The form of the equation was changed to include a function of the total pressure in place of the reference pressure term.

$$
P_{r e f}=C_{1}+C_{2} * P_{T}
$$

Where:

$\mathrm{P}_{\mathrm{T}}=$ total pressure, $(\mathrm{atm})$

$\mathrm{C}_{1}, \mathrm{C}_{2}=$ linear curvefit constants

The constants $\mathrm{Kc}, \mathrm{N}$, and Eact in the current exchange density equation are adjusted to fit the data. The new model comparisons to data are shown below in Figures 6.4 through 6.7 which show reasonably good agreement to the data. A more rigorous approach to determining an optimum fit could be employed but was not done on this program.

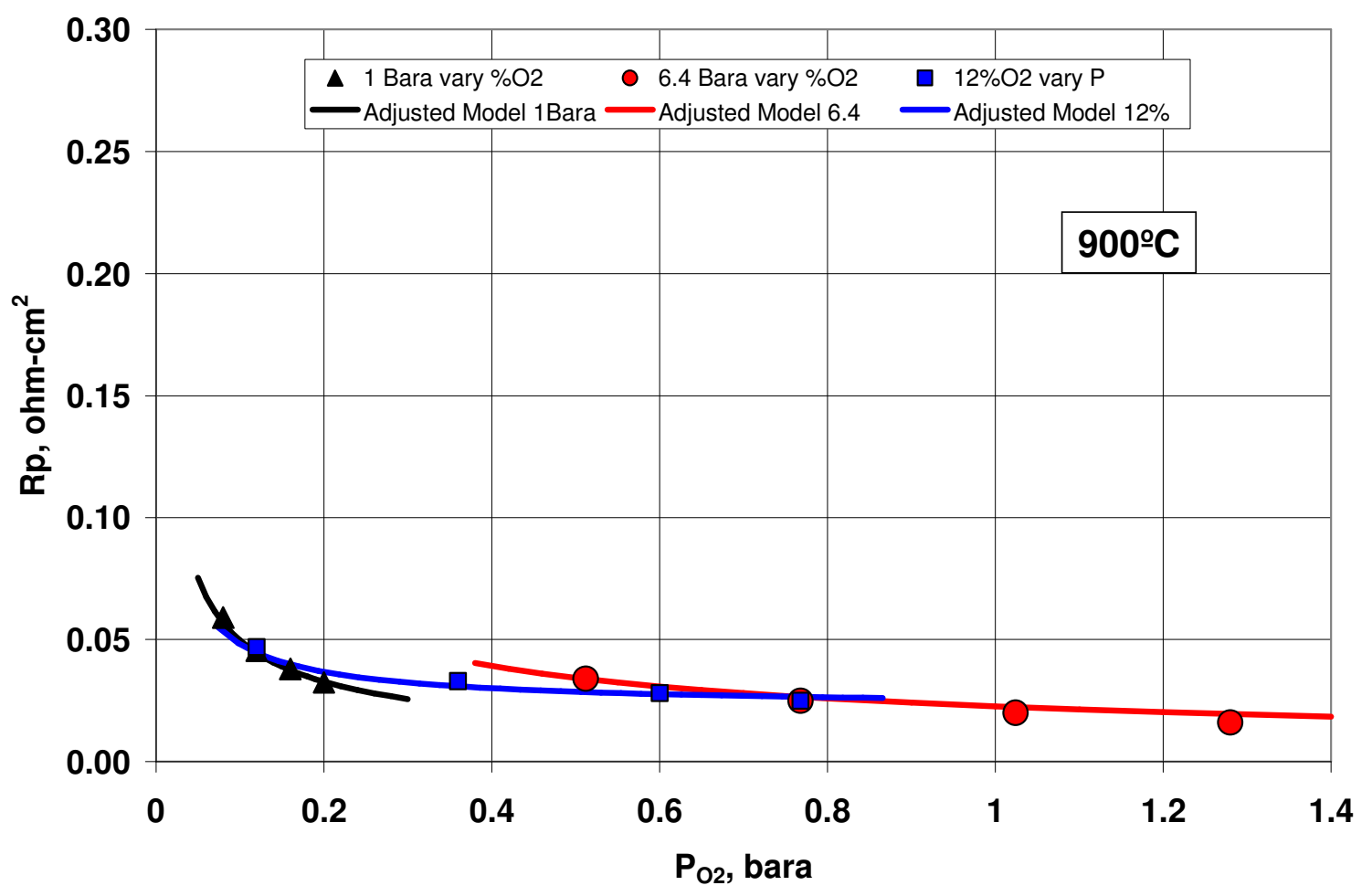

Figure 6.4 - Adjusted Model Comparison at $900^{\circ} \mathrm{C}$ 


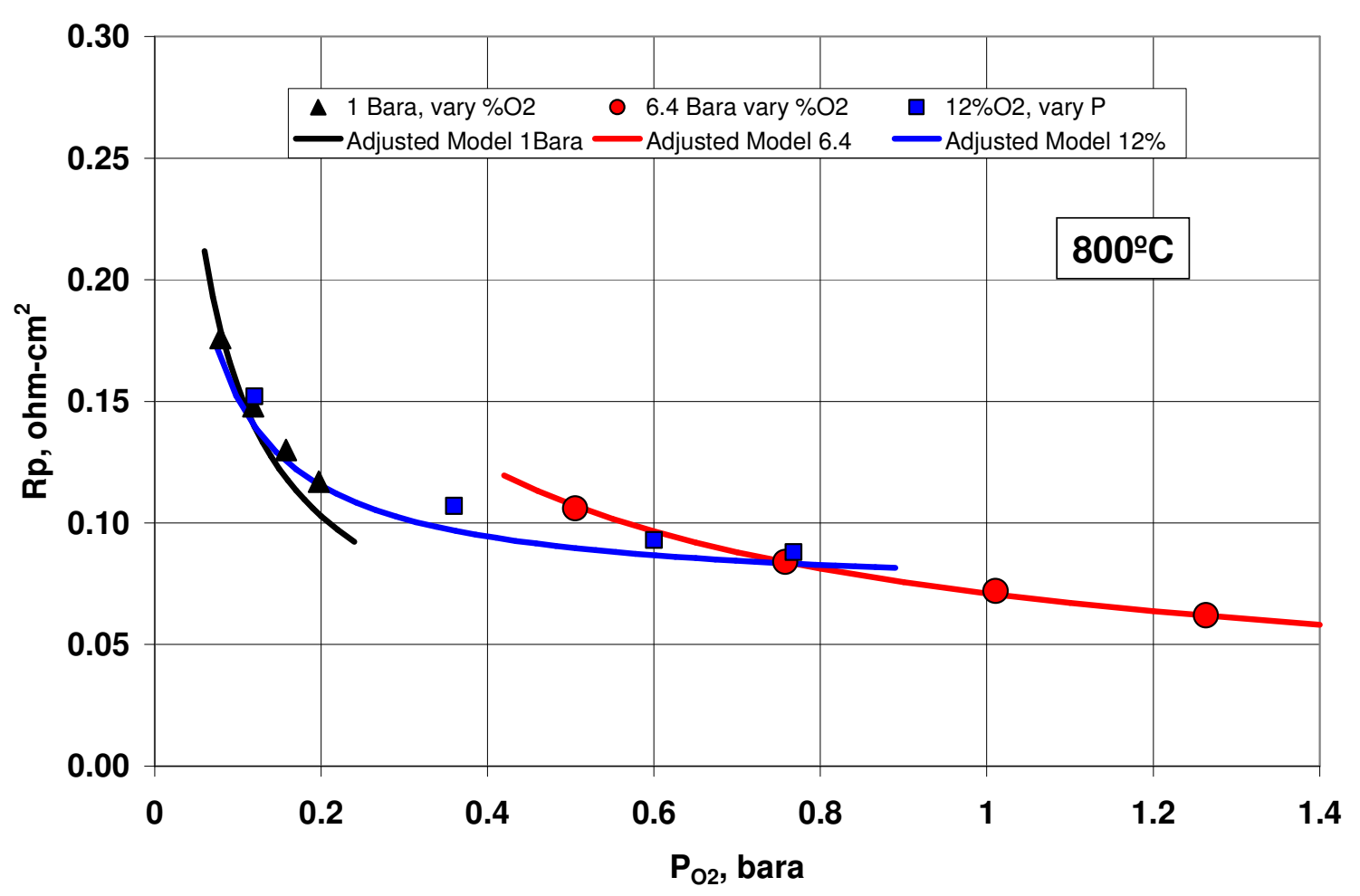

Figure 6.5 - Adjusted Model Comparison at $8^{\circ 00} \mathrm{C}$

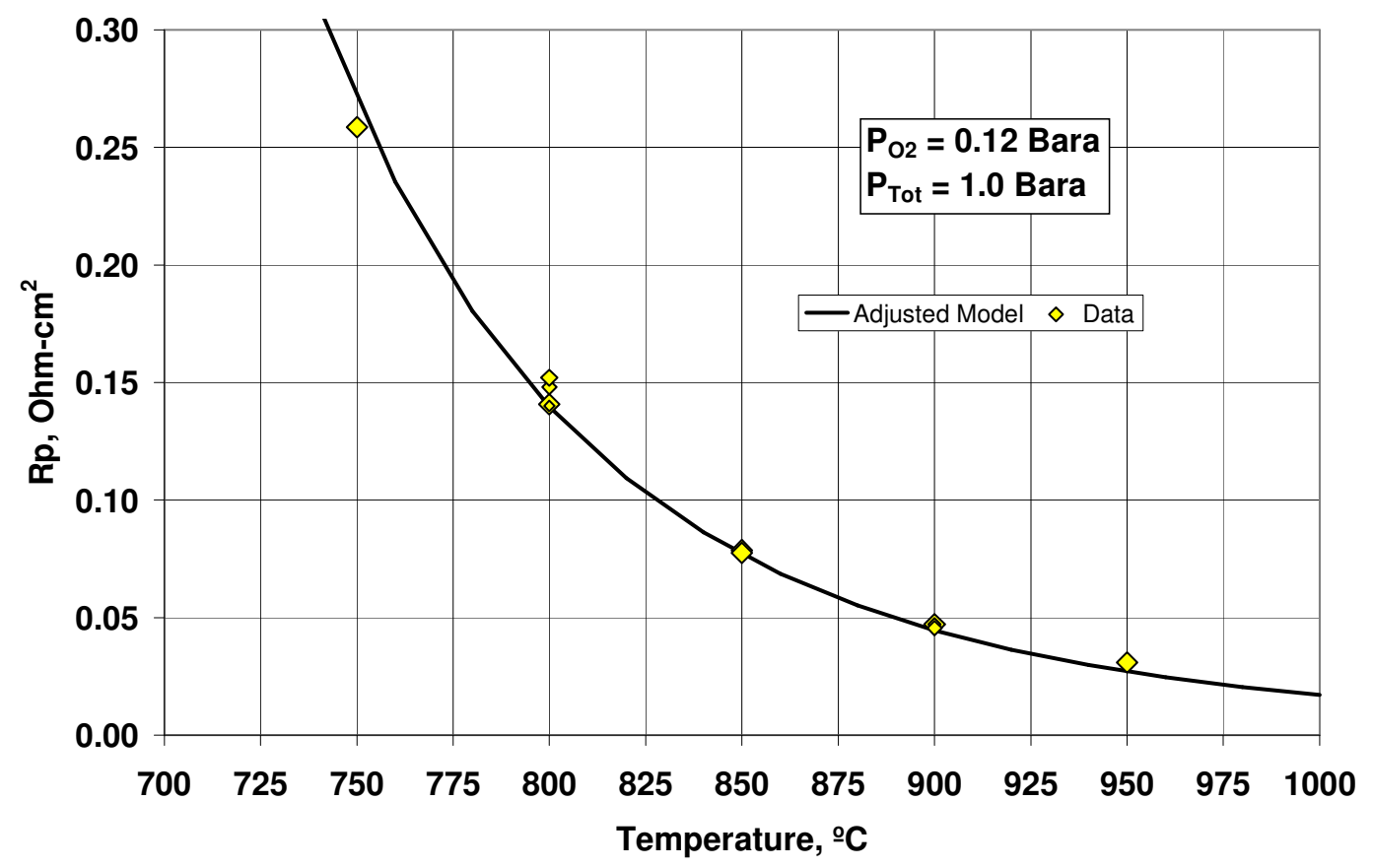

Figure 6.6 - Rp versus Temperature at $12 \% \mathrm{O} 2$ and 1.0 Bara 


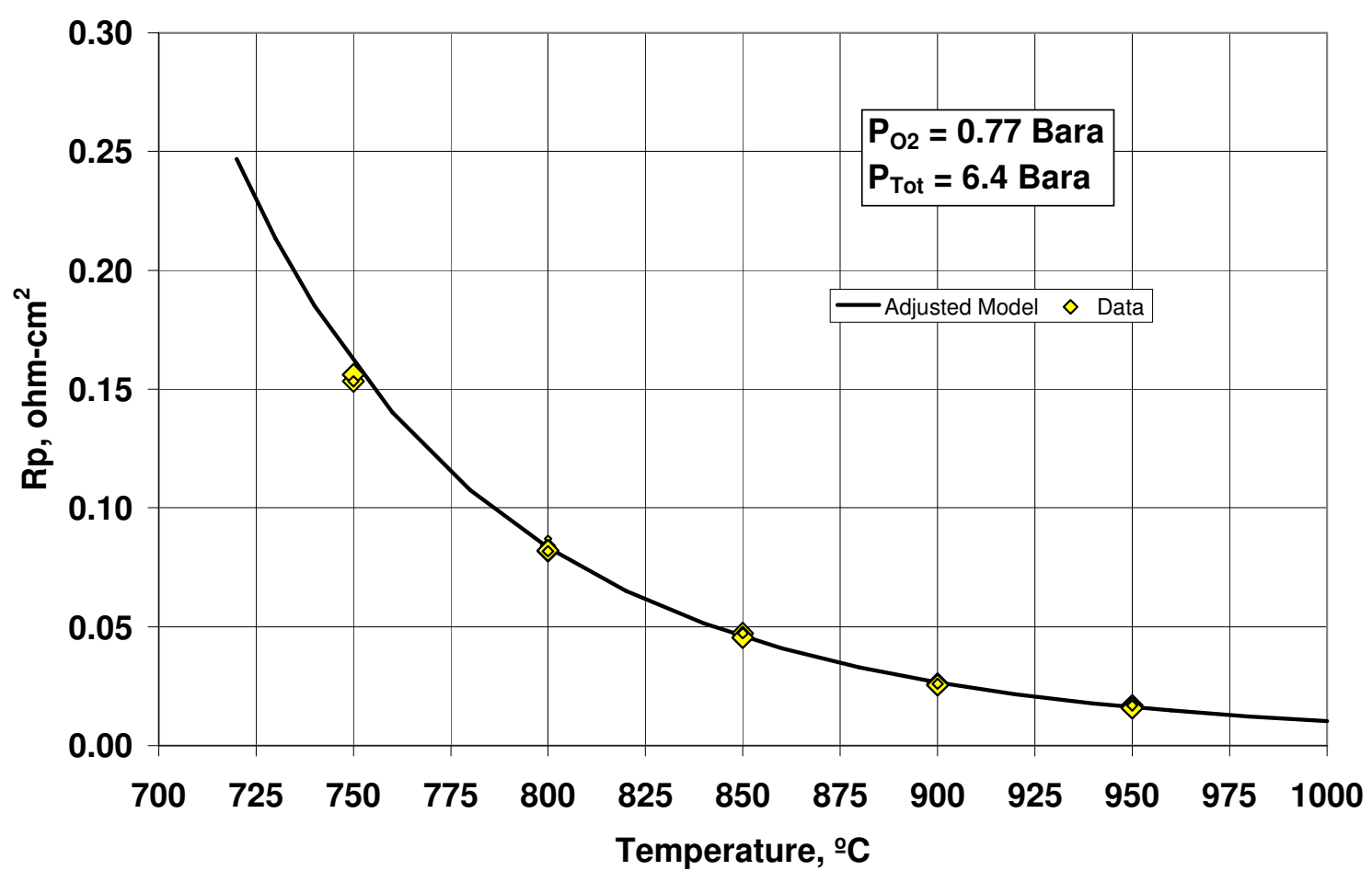

Figure 6.7 - Rp versus Temperature at $12 \% 02$ and 6.4 Bara

\section{Fitting Full Fuel Cell Data}

Finally, after all other parts of the cell loss have been either fit to data or calculated the full fuel-cell data is used to determine the adjustment to the anode activation.

After going though the process for several sets of data, the model was set and then compared to test data taken over a range of conditions. Figures 6.8 through 6.10 show an example of the comparison for TCT35. As shown, the overall comparison is reasonable considering the variation in the two samples shown. The breakdown of the polarization and ohmic loss components is reasonable, although the limitations of the anode side diffusion model are exposed when a dilute fuel composition was used. This finding led to later enhancements using the Cylindrical Pore Interpolation Model, or $\mathrm{CPIM}^{7}$ to model the complexity of this process (work not sponsored by this program). The substrate thickness, porosity, and tortuosity are key parameters needed for this model.

In summary the facilities in use and the data produced by them provides sufficient detail and range of operation to provide a robust set of data for model development and validation.

\footnotetext{
7 "Modelling of multi-component gas flows in capillaries and porous solids", J.B. Young *, B. Todd Hopkinson Laboratory, Cambridge University, Engineering Department, International Journal of Heat and Mass Transfer 48 (2005) 5338-5353, Received 2 March 2005
} 


\section{Comparison of Overall Cell ASR}

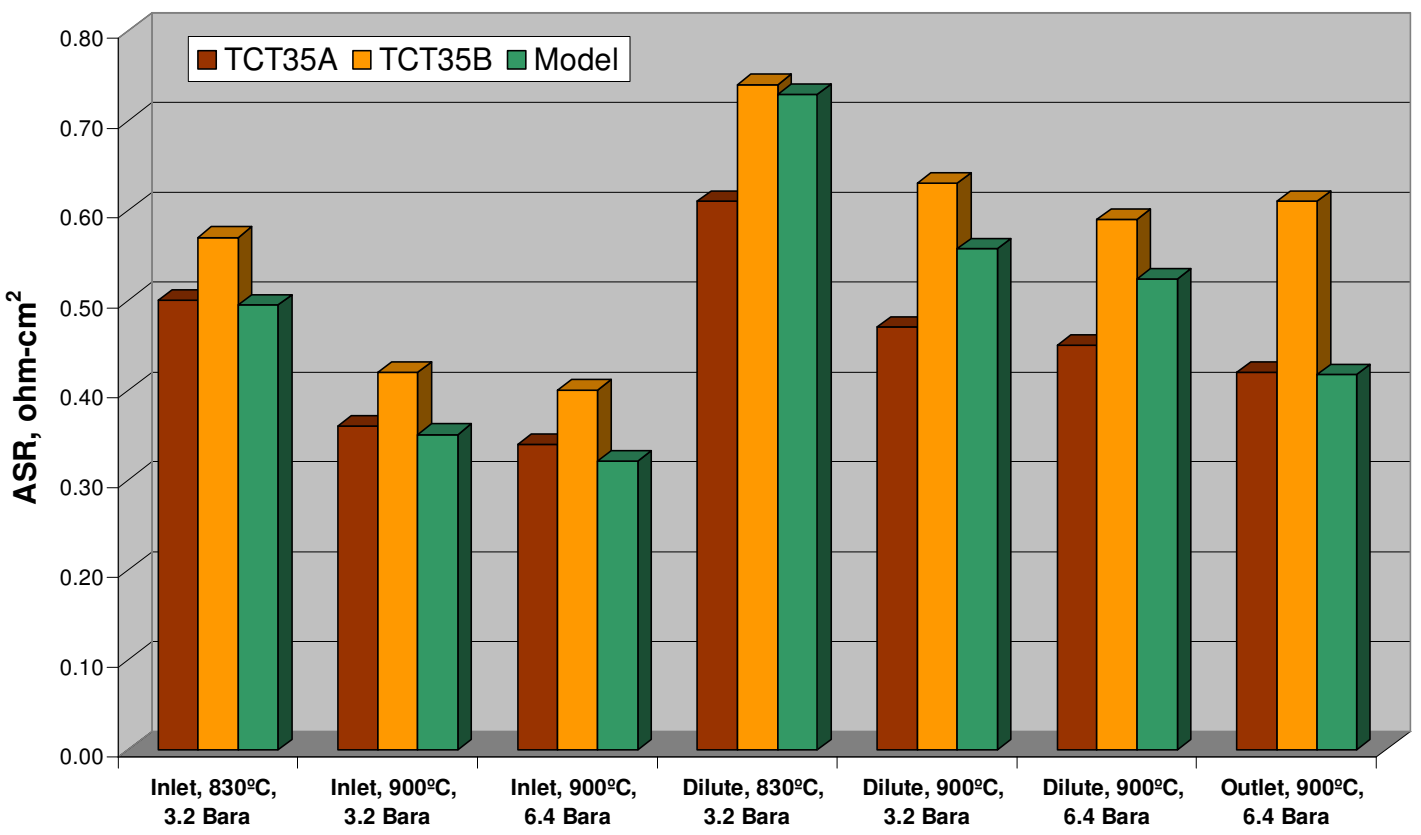

Figure 6.8 Comparison of Overall Model to Overall Cell ASR for TCT35

Comparison of Cell Rp Predictions for TCT35

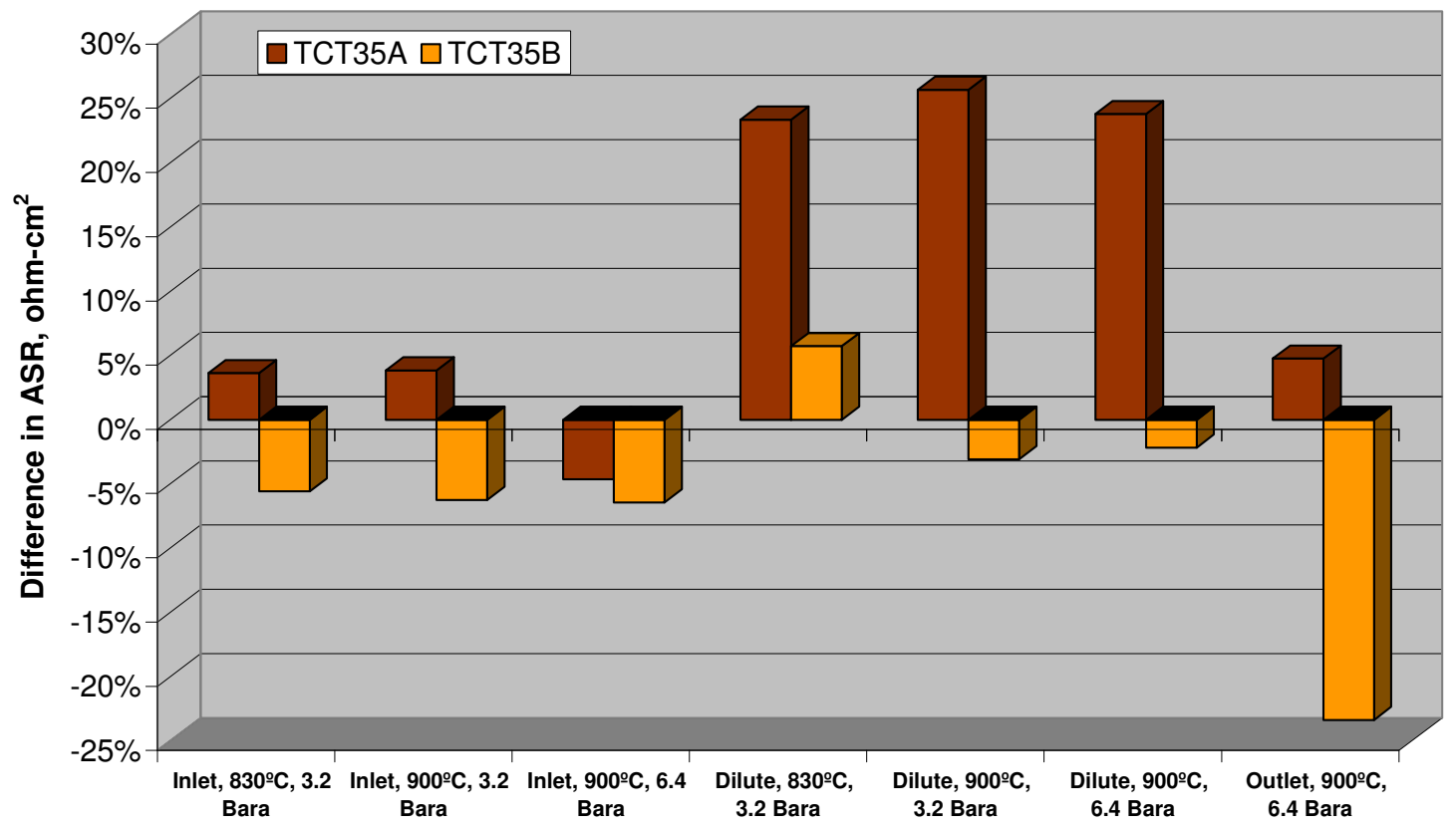

Figure 6.9 Comparison of Polarization Prediction to Data for TCT35 


\section{Comparison of Cell Rs Predictions for TCT35}

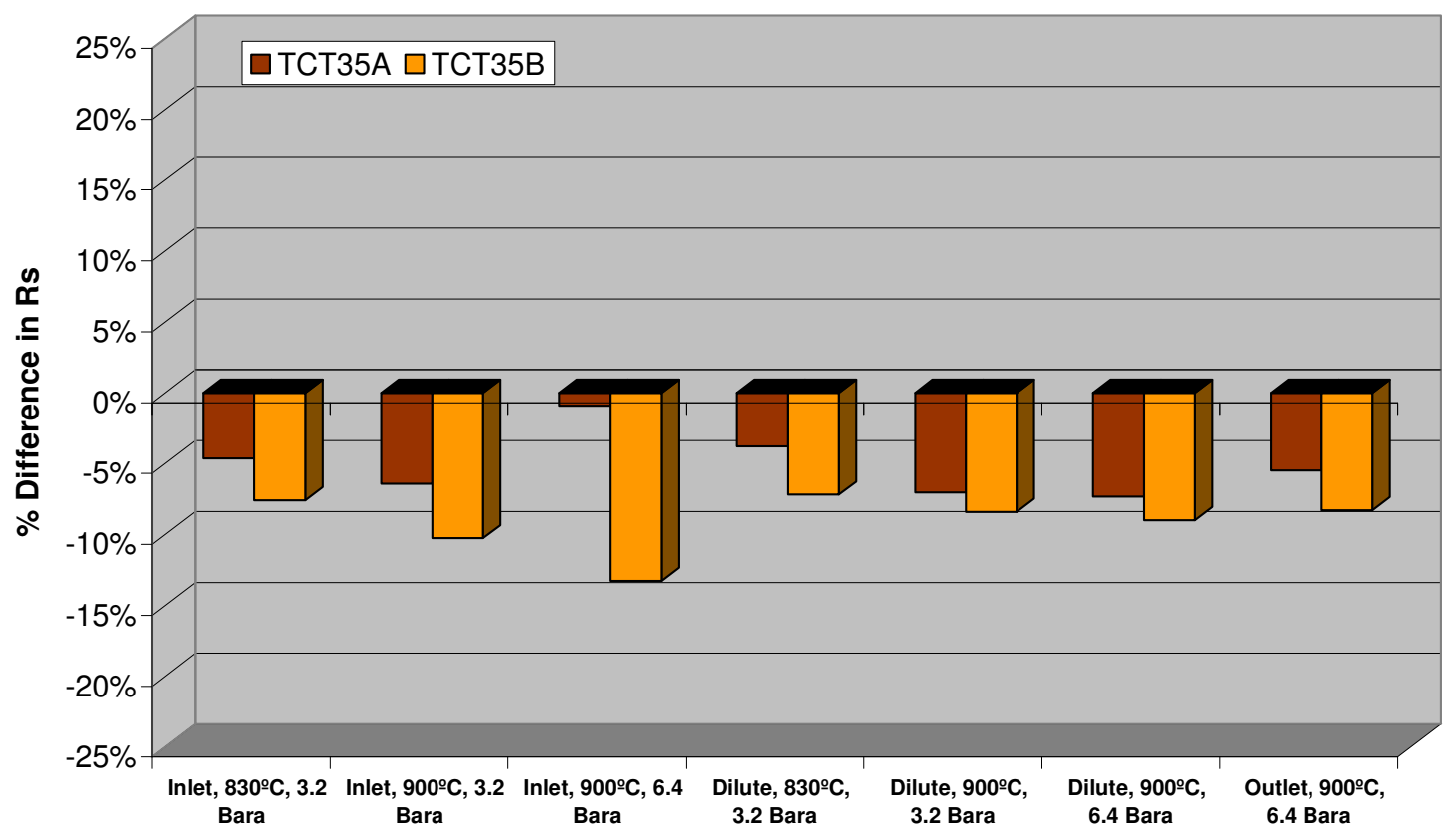

Figure 6.10 Comparison of Ohmic Loss Prediction to Data for TCT35 


\section{Conclusion}

The data acquired in this program has shown a clear performance benefit to operating solid oxide fuel cells at pressure. The improved performance includes of course increased Nernst potential, but also includes cathode activation, anode activation, and anode diffusion (for anode supported type cells). Improvement in cathode electrode performance is on the order of $33-40 \%$ at pressures of 6.4 Bara compared to atmospheric pressure. Key cathode operational parameters are the concentration and partial pressure of $\mathrm{O}_{2}$, and temperature. The effect of partial pressure of oxygen $\left(\mathrm{P}_{\mathrm{O}_{2}}\right)$ decreases the activation polarization, although there appears to be a secondary effect of absolute pressure as well. The ASR reduction for the full fuel-cell was on the order of $0.10 \mathrm{ohm}-\mathrm{cm}^{2}$ for a pressure increase from 1 to 6.5 Bara, with about $70 \%$ of the improvement being realized from 1 to 4 Bara.

This program shows that pressurized fuel cell operation can be a step toward increases power density as well as fundamental fuel cell efficiency. 


\section{Graphical Materials List}

Figure 1. 1 - Rolls-Royce Series Connected Cells on Substrate ...................................

Figure 1. 2 - Schematic of Series Connected Cell ........................................................

Figure 3.1 - Pressurized Button Cell Apparatus...................................................... 5

Figure 3.2 - Pressurized Button Cell Test Setup................................................... 6

Figure 3. 3 - Pressurized Test Stands in Ventilated Enclosure ................................ 7

Figure 3. 4 - Pressurized Test Stand Showing Pressure Vessel ................................ 8

Figure 3. 5 - Pressurized Test Setup with Vessel Removed ..................................... 8

Figure 3.6 - Triple Cell Test Sample ...................................................................... 9

Table 4. 1 Matrix of Test Conditions for Pressurized Button Cell Tests.........................10

Figure 4.1 Effect of Pressure on Cathode Polarization at $800^{\circ} \mathrm{C}$ and $12 \% \mathrm{O}_{2} \ldots \ldots \ldots \ldots . . . .11$

Figure 4.2 Effect of Pressure on Cathode Polarization at $900^{\circ} \mathrm{C}$ and $12 \% \mathrm{O}_{2} \ldots \ldots \ldots \ldots . . . .11$

Figure 4.3 Summary of Pressure Effect Data at Two Temperatures..........................11

Figure 4.4 Activation Energy at 1 and 6.4 Bara, 12\% O2 ....................................... 12

Figure 4.5 Effect of Pressure and Oxygen Concentration on Activation Energy............13

Figure 4.6 Effect of Pressure and $\mathrm{O}_{2}$ Concentration of Cathode $\mathrm{Rp}$ at $900^{\circ} \mathrm{C} \ldots \ldots \ldots \ldots . . . . .14$

Figure 4.7 Effect of Pressure and $\mathrm{O} 2$ Concentration of Cathode $\mathrm{Rp}$ at $850^{\circ} \mathrm{C} \ldots \ldots \ldots \ldots . . . .14$

Figure 4.8 Effect of Pressure and $\mathrm{O}_{2}$ Concentration of Cathode $\mathrm{Rp}$ at $800^{\circ} \mathrm{C} \ldots \ldots \ldots \ldots . . . .15$

Figure 4.9 Impedance Data from $\mathrm{O}_{2}$ Test Matrix at 6.4 Bara and $900^{\circ} \mathrm{C} \ldots \ldots \ldots \ldots \ldots \ldots \ldots . . . \ldots 15$

Figure 4.10 Cross-section of typical button cell sample .............................................16

Figure 4.11 Low Frequency (diffusion) Portion of Cathode Polarization.........................16

Figure 4.12 High Frequency (activation) Portion of Cathode Polarization .....................17

Figure 4.13 Effect of $\mathrm{CO}_{2}$ on Cathode $\mathrm{Rp}, 850^{\circ} \mathrm{C}$, 6.4 Bara, Constant $\mathrm{P}_{\mathrm{O} 2} \ldots \ldots \ldots \ldots \ldots . . . . . .17$

Figure 4.14 Effect of Steam on Cathode Performance for Short Term Test..................18

Figure 4.15 Effect of $\mathrm{P}_{\mathrm{H} 2 \mathrm{O}}$ on Cathode Performance for Short Term Test .....................18

Figure 4.16 Comparison of Degradation Traces under Constant Current Load ............19

Figure 4.17 Impedance Traces at 0 and 500 hours at 900C, Dry Cathode, and ..........19

Figure 4. 18 Impedance Traces at 0 and 500 hours at 900C, Wet Cathode, and..........20

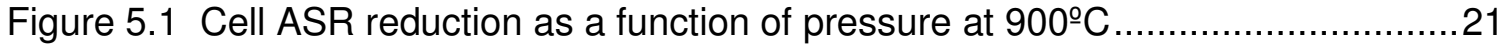

Figure 5.2 Effect of Pressure on Performance of a Triple-Cell Sample at $900^{\circ} \mathrm{C} \ldots \ldots \ldots . .22$

Figure 5. 3 Impedance Trace of TCT26 at 900 ${ }^{\circ} \mathrm{C}, 1$ and 3.2 Bara ..............................22

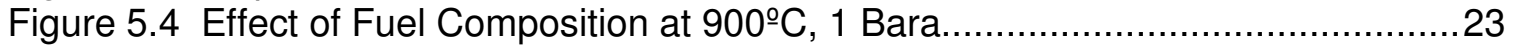

Figure 5.5 Effect of Fuel Composition at $900^{\circ} \mathrm{C}, 6.5$ Bara.......................................23

Figure 5.6 Effect of Oxygen Concentration on Cell ASR at 6.4 Bara and $860^{\circ} \mathrm{C} \ldots \ldots \ldots . .24$

Figure 5.7 Short-term Effect of 13\% Steam on Performance at 1 and 6.5 Bara............25

Figure 5.8 Time Trace Showing Reduced ASR after Cathode Steam is Removed .......25

Figure 5.9 Impedance Trace for TCT40A at 38 and 59 Hours ...................................26

Figure 5.10 Effect of Steam and Temperature for Pre-Burn-in Case ..........................27

Figure 5.11 Effect of Steam and Temperature for Post-Burn-in Case ..........................27

Figure 5.12 Time Trace for 0 - 500 Hours on Triple-Cell Samples .............................28

Figure 5.13 Time Trace for 500 - 1000 Hours on Triple-Cell Samples .......................28

Figure 6.1 - Example Showing Impedance Data from Fuel Cell Test...........................31

Figure 6.2 - Porous structure of fuel cell for gas diffusion ............................................ 32

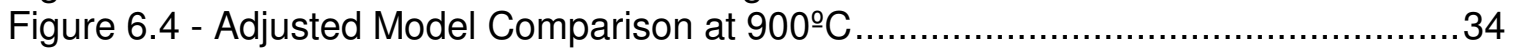




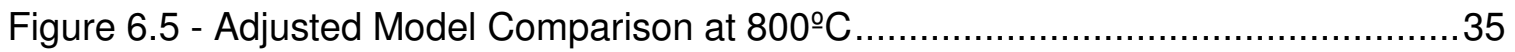

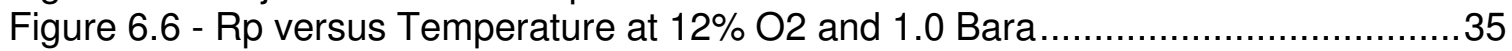

Figure 6.7 - Rp versus Temperature at $12 \% \mathrm{O} 2$ and 6.4 Bara.................................... 36

Figure 6.8 Comparison of Overall Model to Overall Cell ASR for TCT35 ......................37

Figure 6.9 Comparison of Polarization Prediction to Data for TCT35......................... 37

Figure 6.10 Comparison of Ohmic Loss Prediction to Data for TCT35........................38

\section{References and Bibliography}

1. "Parametric study of solid oxide fuel cell performance", Meng Ni, Michael K.H. Leung

*, Dennis Y.C. Leung, Department of Mechanical Engineering, The University of Hong Kong, Energy Conversion and Management 48 (2007) 1525-1535, Received 17 May 2006; accepted 26 November 2006

2. "On the mechanisms and behavior of coal syngas transport and reaction within the anode of a solid oxide fuel cell", R.S. Gemmen, J. Trembly, National Energy Technology Laboratory, Journal of Power Sources 161 (2006) 1084-1095, Received in revised form 23 May 2006; accepted 6 June 2006

3. "Characteristics of anodic polarization of solid oxide fuel cells under pressurized conditions", Ryuji Kikuchia, Tatsuya Yanoa, Tatsuya Takeguchib, Koichi Eguchia, Solid State Ionics 174 (2004) 111 -117, Received 5 February 2004; accepted 29 May 2004

4. "Electrode Studies at High Pressure", Larry Pederson, Ben McCarthy, Matt Chou, Greg Coffey, Chris Coyle, Olga Marina, Carolyn Nguyen, Ed Thomsen, and Xiao-Dong Zhou, 8th Annual SECA Workshop, San Antonio TX, August 7-9, 2007

5. "Oxygen electrode reaction on stabilized zirconia under high oxygen pressure (up to 100 bar)", C. Drevet, M. He'nault, J. Fouletier, Solid State lonics 136-137 (2000) 807812

6. Electrochemical model of the integrated planar solid oxide fuel cell (IP-SOFC), Paola Costamagna, Azra Selimovic, Marco Del Borghi, Gerry Agnew, Chemical Engineering Journal 102 (2004) 61-69, 22 February 2004

7. "Modelling of multi-component gas flows in capillaries and porous solids", J.B. Young *, B. Todd Hopkinson Laboratory, Cambridge University, Engineering Department, International Journal of Heat and Mass Transfer 48 (2005) 5338-5353, Received 2 March 2005 


\section{List of Acronyms and Abbreviations}

RRFCS: Rolls-Royce Fuel Cell Systems

SOFC: Solid Oxide Fuel Cell

PO2: Partial pressure of oxygen

MW: megawatt

TPB: triple point boundary

SMR: Steam methane reforming

WGS: Water gas shift

PIC: primary interconnect

SIC: secondary interconnect

LSM: Lanthanum-Strontium-Manganate

YSZ: Yttria-Stabilized Zirconia

EIS: electro-impedance spectroscopy

Rs: electronic resistance

Rp: electrode resistance due to polarization

TCT: triple-cell-test

CPIM: cylindrical pore interpolation model 